\title{
ANNOTATED GEOTHERMAL BIBLIOGRAPHY OF UTAH
}

\section{Rerowad ty}

JUN $O 21986$

Karin E. Budding and

Miriam H. Bugden, Compilers

UTAH GEOLOGICAL AND MINERAL SURVEY a division of UTAH DEPARTMENT OF NATURAL RESOURCES BULLETIN 121

1986

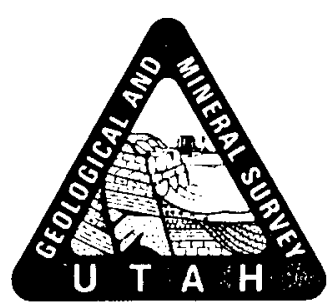




\section{DISCLAIMER}

This report was prepared as an account of work sponsored by an agency of the United States Government. Neither the United States Government nor any agency Thereof, nor any of their employees, makes any warranty, express or implied, or assumes any legal liability or responsibility for the accuracy, completeness, or usefulness of any information, apparatus, product, or process disclosed, or represents that its use would not infringe privately owned rights. Reference herein to any specific commercial product, process, or service by trade name, trademark, manufacturer, or otherwise does not necessarily constitute or imply its endorsement, recommendation, or favoring by the United States Government or any agency thereof. The views and opinions of authors expressed herein do not necessarily state or reflect those of the United States Government or any agency thereof. 


\section{DISCLAIMER}

Portions of this document may be illegible in electronic image products. Images are produced from the best available original document. 
STATE OF UTAH

Norman H. Bangerter, Governor

DEPARTMENT OF NATURAL RESOURCES

Dee C. Hansen, Executive Director

UTAH GEOLOGICAL AND MINERAL SURVEY

Genevieve Atwood, Director

\section{BOARD}

James H. Gardner, Chairman $\ldots \ldots \ldots \ldots \ldots \ldots \ldots \ldots \ldots \ldots \ldots \ldots \ldots \ldots \ldots \ldots \ldots \ldots \ldots \ldots \ldots$ University of Utah

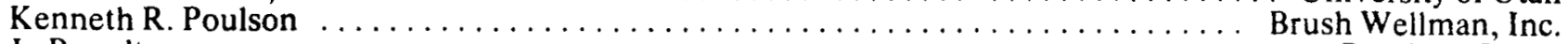

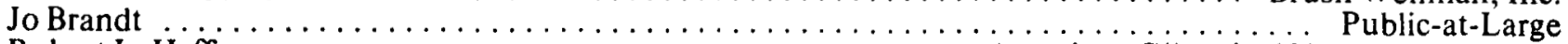

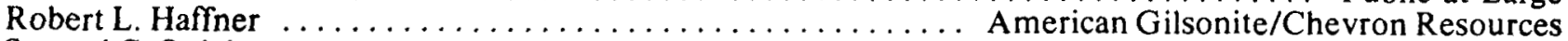
Samuel C. Quigley ................................... Tower Resources, Inc.

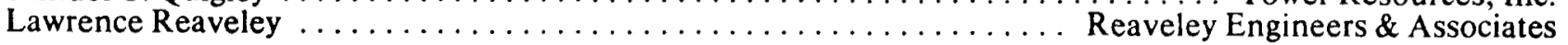
Ralph A. Miles, Director, Division of State Lands ................ ex officio member

\section{UGMS Editorial and Illustrations Staff}

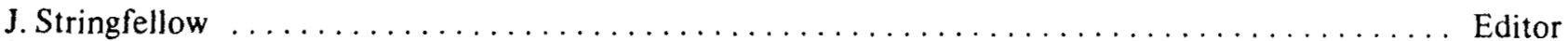
Leigh M. MacManus, Carolyn Olsen . . . . . . . . . . . . . . . . . . . . . . . . . Editorial Staff Kent D. Brown, James W. Parker, Patricia H. Speranza $\ldots \ldots \ldots \ldots \ldots \ldots \ldots \ldots \ldots \ldots \ldots \ldots \ldots \ldots$ Cartographers 
Available from

National Technical Information Services

U.S. Department of Commerce

5285 Port Royal Road

Springfield, VA 22161

NTIS Price Codes: Printed Copy A0

Microfiche A0

DISCLAIMER

This book was prepared as an account of work sponsored by an agency of the United States Government. Neither the United States Government nor any agency thereof, nor any of their employees, makes any warranty, express or implied, or assumes any legal liability or reponsibility for the accuracy, completeness, or usefulness of any information, apparatus, product or process disclosed, or represents that its use would not infringe privately owned rights. References herein to any specific commercial product, process, or service by trade name, trademake, manufacturer, or otherwise, does not necessarily constitute or imply its endorsement, recommendation, or favoring by the United States Government or any agency thereof. 


\section{ANNOTATED GEOTHERMAL BIBLIOGRAPHY OF UTAH}

Karin E. Budding and

Miriam H. Bugden, Compilers

UTAH GEOLOGICAL AND MINERAL SURVEY 
TABLE OF CONTENTS

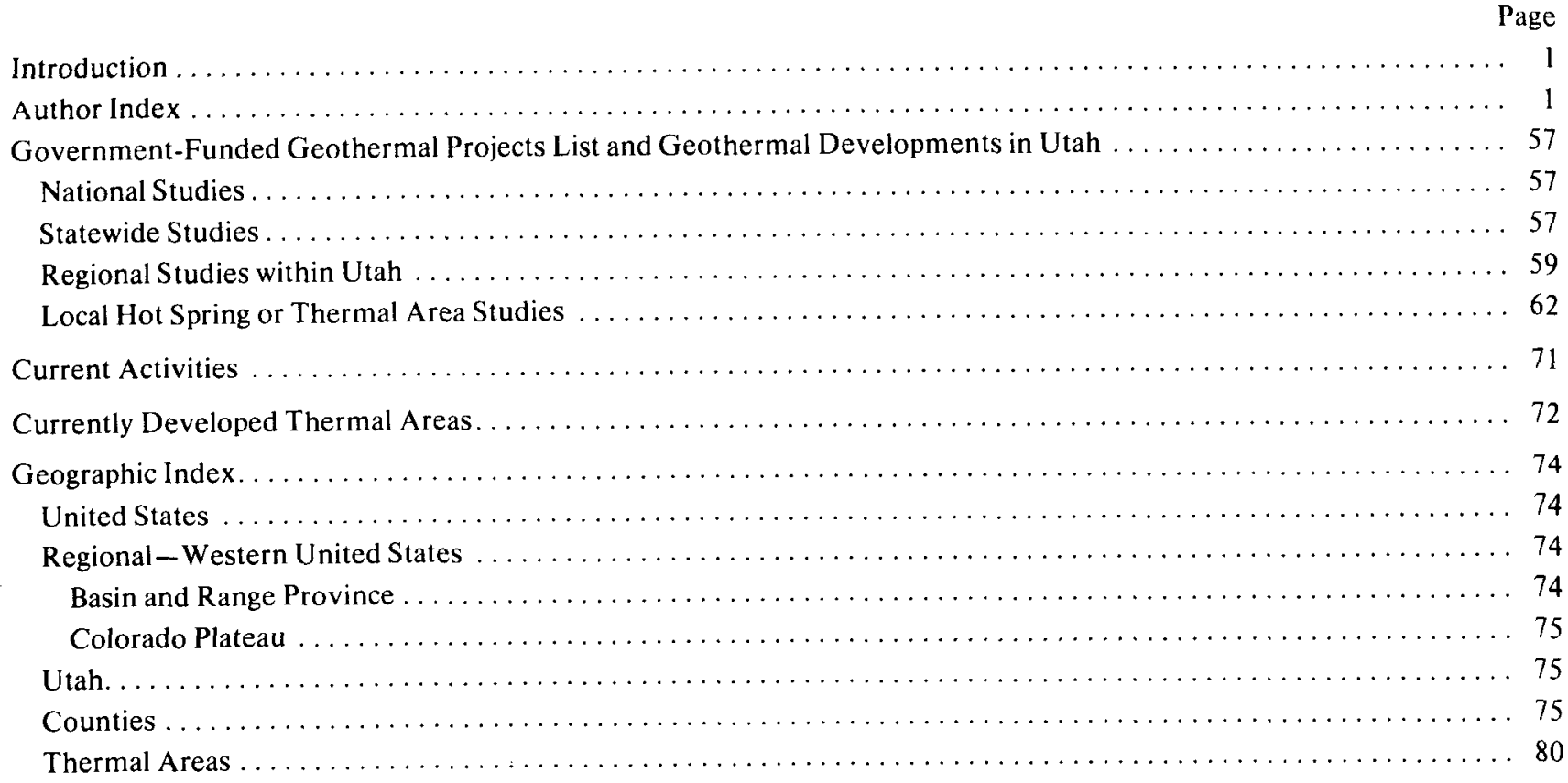

\section{ILLUSTRATION}

Figure 1. Map of Utah counties, thermal areas, and physiographic provinces listed in the geographic index.

High-temperature areas have geological and geophysical references in bibliography. 


\title{
ANNOTATED GEOTHERMAL BIBLIOGRAPHY OF UTAH
}

\author{
Karin E. Budding and Miriam H. Bugden, Compilers
}

\section{INTRODUCTION}

The geothermal bibliography of Utah was compiled under Department of Energy (DOE) Grant DEFG07-84ID12543. Utah Geological and Mineral Survey (UGMS) staff assisting in the compilation included Kathleen A. Murphy, Patricia H. Speranza, and Sandra N. Eldredge.

The following sources were used in compiling the bibliography: 1) UGMS Bibliography of Utah Geology, 2) GEOREF, 3) DOE Energy Data Base, 4) Annotated and Indexed Bibliography of Geothermal Phenomena, 5) Earth Science Laboratory/University of Utah Research Institute publications, 6) U.S. Geological Survey publications, 7) UGMS publications, 8) graduate theses, 9) Geothermal Resources Council publications, 10) United Nations symposia, and 11) private industry publications. We have attempted to include all of the Utah geothermal references through 1984. Some 1985 citations are listed. Geological, geophysical, and tectonic maps and reports are included if they cover a high-temperature thermal area ( $\bullet$ on fig. 1 ) because this information is critical to the understanding of a geothermal resource.

Those references which directly pertain to a geothermal resource are annotated. The annotations are intended to inform the reader of the information contained in the article, not to summarize the results.

Accompanying the bibliography is a list and description of geothermal projects and commercial geothermal developments in Utah from 1966 to the present that have been wholly or partially funded through Federal or State programs. The references listed in the project descriptions are keyed to the bibliography. Most of this work is by government agencies or universities. Private or industry-funded geothermal developments are not listed.

The following organizations provide information and publications on geothermal resources in Utah. State divisions in the Department of Natural Resources include the Utah Geological and Mineral Survey, Division of Water Rights, and the Utah Energy Office. Federal agencies in the Department of the Interior include the U.S. Geological Survey Public Inquires Office and the Division of Water Resources. The Earth Science Laboratory of the University of Utah Research Institute is another source of information and publications.

The references are indexed geographically either under 1) United States (national studies), 2) regional-western United States or physiographic province, 3) Utah-statewide and regional, or 4) county. Reports concerning a particular hot spring or thermal area are listed under both the thermal area and the county names. The thermal areas indexed are shown on figure 1 (on page 73 ).

\section{AUTHOR INDEX}

ABOU-SAYED, A. S., Buchholdt, L. M., and Jones, A. H., 1977 , Studies of geothermal reservoir stimulation by hydraulic fracturing, draft final report: Terra Tek Report, no. TR 77-119, $78 \mathrm{p}$.

ADHIDJAJA, J. I., 1981, Study of major geologic structures indicated by gravity data in the Richfield $1 \times 2$ degree quadrangle, Utah: Salt Lake City, Utah, University of Utah, unpublished Masters thesis, $77 \mathrm{p}$.

ADHIDJAJA, J. I., Cook, K. L., and Serpa, L. F., 1981, Complete Bouguer gravity anomaly map of Jordan Valley, Utah: Utah Geological and Mineral Survey Open-File Report, no. 39, scale 1:62,500.

AERIAL SURVEYS, 1978a, Cove Fort-Sulphurdale KGRA residual aeromagnetic map covering 190 square miles in Dog Valley: Earth Science Laboratory/University of Utah Research Institute Open-File Report, no. UT/CFS/ESL-1, scale 1:62,500.

Flight parameters included.

AERIAL SURVEYS, 1978b, Cove Fort-Sulphurdale KGRA residual aeromagnetic map covering 190 square miles in Dog Valley: Earth Science Laboratory/University of Utah Research Institute Open-File Report, no. UT/CFS/ESL-2, scale 1:24,000, two sheets.

Flight parameters included.

ALEINIKOFF, J. N., Nielson, D. L., Hedge, C. E., and Evans, S. H., Jr., in press, Geochronology of Precambrian and Tertiary rocks from the Mineral Mountains, south-central Utah, in Shorter contributions to isotope research: U.S. Geological Survey Bulletin 1622.

ALlEN, E. G., Pera, E. M., Smedley, J. E., and Lutz, G. A., 1977, Leasable mineral and waterpower land classification map of the Ogden quadrangle, Utah: U.S. Geological Survey Open-File Report 77-604, scale 1:250,000.

ALLEN, T. S., 1983, Roosevelt Hot Springs unit development (abs.): American Association of Petroleum Geologists Bulletin, v. 67, no. 8, p. 1329.

Date of unitization of Roosevelt Hot Springs unit; current production plans; outline of development procedures from 1976 to 1984.

AMES, L. L., Jr., and Sand, L. B., 1959, Halloysite formed in a calcareous hot springs environment (Utah), in Swineford, A., ed., Clays and clay minerals: International Earth Science Monograph Series, v. 2, p. 378-385.

ANDERSON, R. E., 1978, Quaternary tectonics along the intermountain seismic belt south of Provo, Utah: Brigham Young University Geology Studies, v. 25, pt. 1, p. $1-10$.

ANNO, G. H., Dore, M. A., Grijalon, R. L., Lang, G. D., and Thomas, F. J., 1978, Hybrid geothermal/fossil 
power plants: a site specific analysis: American Nuclear Society, Transactions, v. 28, p. 15-16.

ARMSTRONG, R. L., 1963, K-Ar ages of volcanics in southwestern Utah and adiacent Nevada, in Heylmun, E. B., ed., Geology of southeastern Utah: Intermountain Association of Petroleum Geologists Guidebook, 12th Annual Field Conference, p. 79-80.

ARMSTRONG, R. L., 1970, Geochronology of Tertiary igneous rocks, eastern Basin and Range Province, western Utah, eastern Nevada, and vicinity, U.S.A.: Geochimica et Cosmochimica Acta, v. 34, p. 203-232.

ASH, D. L., Dondanville, R. F., and Gulati, M. S., 1979, Geothermal reservoir assessment, Cove FortSulphurdale unit; final report for the period September, 1977 - July, 1979: Department of Energy Report, no. DOE/ET/28405-1, 34 p.

Purpose of report; map showing locations of Cove FortSulphurdale unit wells; drilling summary of four wells; summary of lost circulation in wells; discussion of oxygen corrosion rates while drilling two wells; summary of the geology of four exploratory geothermal wells; static fluid levels and temperature gradients from the four wells; chart showing geochemistry of formation waters encountered in the Cove Fort-Sulphurdale unit area; generalized lithologic logs of three wells; three summaries of downhole logging tables; reservoir analysis of Cove Fort-Sulphurdale unit based on tests from two wells.

ASTEN, M. W., 1983, Discussion on "Seismic array noise studies at Roosevelt Hot Springs, Utah geothermal area", by E. J. Douze and S. J. Laster: Geophysics, v. 48 , no. 11 , p. 1560 .

Douze and Laster's equation for the vertical component of isotropic single-mode Rayleigh wave noise; rebutal to statement that apparent phase velocities cannot be obtained from existing data.

ATKINSON, D. J., 1981, The Roosevelt field: new model and geochemical evaluation: Geothermal Resources Council, Transactions, v. 5, p. 149-152.

Structural and geologic setting of Roosevelt Hot Springs; air photo interpretation of four major fault systems; three dimensional geometry of rock masses and difficulties in defining field boundaries; heat flow patterns based on 53 drill holes; analyses of ground water in wells and springs; reservoir water characteristics and flow patterns; soil and surface microlayer samples and their geochemical anomalies used in geothermal exploration.

ATKINSON, D. J., and Meyer, W. T., 1980, Low cost airborne geochemical detection and evaluation of "blind" geothermal resources: Geothermal Resources Council, Transactions, v. 4, p. 141-144.

BAER, J. L., and Rigby, K. J., 1978, Geology of the Crystal Geyser and environmental implications of its effluent, Grand County, Utah: Utah Geology, v. 5, no. 2, p. 125-130.
BAKER, C. H., Jr., 1968, Thermal springs near Midway, Utah, in Geological Survey research: U.S. Geological Survey Professional Paper 600-D, p. D63-D70.

Describes thermal springs and associated tufa mounds; chemical analyses of waters and tufa deposits; inferred origin of springs.

BAKER, C. H., Jr., 1969, Hot pots near Midway, Utah (abs.): Geological Society of America Abstracts with Programs, pt. 5, p. 4.

Location and general geology of the Midway hot pots; water migration paths and accumulation of dissolved solids; water temperatures.

BALLANTYNE, J. M., 1980, Geochemistry of sericite and chlorite in well 14-2, Roosevelt Hot Springs geothermal system and in mineralized hydrothermal systems: Earth Science Laboratory/University of Utah Research Institute Report, no. DOE/ET/28392-43, 101 p.

Evaluates the use of alteration mineral chemistry in geothermal exploration; comparison of sericite and chlorite from fossil hydrothermal systems with sericite and chlorite from a Roosevelt well; analytical techniques and results; thermodynamic interpretation; appendices of sericite and chlorite analyses from fossil and present hydrothermal systems.

BALLANTYNE, J. M., and Parry, W. T., 1978, Hydrothermal alteration at the Roosevelt Hot Springs thermal area, Utah: petrographic characterization of the alteration to two kilometers depth: Earth Science Laboratory/University of Utah Research Institute Report, no. DOE/ET/28392-1, 23 p.

BALLANTYNE, G. H., 1978, Hydrothermal alteration at the Roosevelt Hot Springs thermal area, Utah: Characterization of rock types and alteration in Getty Oil Company well Utah State 52-21: Earth Science Laboratory/University of Utah Research Institute Report, no. DOE/ET/28392-12, 24 p.

Petrography, $\mathrm{X}$ ray diffraction of clay minerals, whole rock analyses, and microprobe analyses of drill cuttings from Getty well 52-21; microprobe analyses of plagioclase, alkali feldspar, biotite, and hornblende; intensity and mineralogy of hydrothermal alteration assemblages; rock types encountered in drill hole; table of whole rock chemical analyses; table of plagioclase alteration versus drill hole depth; table of mineral assemblages versus drill hole depth.

BALLANTYNE, J. M., 1978, Hydrothermal alteration at the Roosevelt Hot Springs thermal area, Utah: modal mineralogy, and geochemistry of sericite, chlorite, and feldspar from altered rocks, Thermal Power Company well Utah State 14-2: Earth Science Laboratory/University of Utah Research Institute Report, no. DOE/ET/28392-16, 42 p.

Microprobe chemical analyses of mineral phases (sericite, chlorite, and feldspar) obtained from well cutting 
samples; analytical techniques; modal mineralogy; structural formulas; graph showing changes in alteration assemblages with depth.

Petrographic study of hydrothermal alteration in cuttings from a drill hole two kilometers in depth; lithologies and alteration in drill hole cuttings; graph showing changes in alteration assemblages with depth.

BALLANTYNE, J. M., and Parry, W. T., 1979, Geochemistry of hydrothermal sericite and chlorite (abs.): Geological Society of America Abstracts with Programs, v. 11 , no. 7 , p. $382-383$.

BAMFORD, R. W., 1978, Geochemistry of solid materials from two U.S. geothermal systems and its application to exploration: University of Utah, Department of Geology and Geophysics Final Report, v. 77-14, 196 p.

BAMFORD, R. W., and Christensen, O. D., 1979, Multielement geochemical exploration data for the Cove Fort-Sulphurdale Known Geothermal Resource Area, Beaver and Millard Counties: Earth Science Laboratory/University of Utah Research Institute Report, no. DOE/ET/28392-28, unpaginated.

Analyses of whole rock samples and of a sample slurry of drill cuttings (specific gravity greater than 3.3) to determine the areal distributions of $\mathrm{As}, \mathrm{Hg}, \mathrm{Pb}$, and $\mathrm{Zn}$; sample methods and preparation; development of models for targeting geothermal drilling from geochemical zonation of elements; previous paleohydrothermal events; generalized geology, alteration, and drill hole location map; figures of $\mathrm{As}, \mathrm{Hg}, \mathrm{Pb}$, and $\mathrm{Zn}$ distribution; temperature gradient map; chemical data and rock type of drill hole samples.

BAMFORD, R. W., Christensen, O. D., and Capuano, R. M., 1980, Multielement geochemistry of solid materials

- in geothermal systems and its application, Part 1: The hot-water system at the Roosevelt Hot Springs KGRA, Utah: Earth Science Laboratory/University of Utah Research Institute Report, no. DOE/ET/27002-7, 168 p.

Development of multielement geochemical techniques based upon analyses of solid materials from the Roosevelt KGRA geothermal system; three-dimensional model of chemical zonation within system; geochemical data derived from chemical and mineralogical analyses of soil fractions, whole rock samples, well fluids, drill chips, and specific gravity concentrate samples; geologic characteristics of geothermal system; detailed element distributions in geothermal wells and near surface; application of solids geochemistry to geothermal exploration and assessment; cost effectiveness of exploration techniques.

BAROSH, P. J., 1960, Beaver Lake Mountains, Beaver County, Utah-their geology and ore deposits: Utah Geological and Mineral Survey Bulletin 68, 89 p.; also, Geoscience Abstracts, v. 2, no. 10, p. 3 (2-2484).

BATTY, J. C., Grenney, W. J., Kaliser, B., Pate, A. J., and Riley, J. P., 1975, Geothermal energy and water resources in Utah, in Impacts of energy development on Utah water resources: Third Annual Conference American Water Resources Association, Utah Section, Proceedings, p. 223-241.

BATZLE, M. L., and Simmons, G., 1976, Geothermal systems; rocks, fluids, fractures, in Keller, G. V. O., and others, eds., The Earth's crust; its nature and physical properties: The Earth's crust; its nature and physical properties, Vail, Colorado; also, 1977, American Geophysical Union, Geophysical Monograph 20, p. 233-242.

BELL, John, 1855, The mineral and thermal springs of the United States and Canada: Philadelphia, Parry and McMillan, p. 13-394.

BENOIT, W. R., and Butler, R. W., 1983, A review of hightemperature geothermal developments in the northern Basin and Range Province, in The role of heat in the development of energy and mineral resources in the northern Basin and Range Province: Geothermal Resources Council Special Report 13, p. 57-80.

BERGE, C. W., Crosby, G. W., and Lenzer, R. C., 1976, Geothermal exploration of Roosevelt KGRA, Utah (abs.), in American Association of Petroleum Geologists and the Society of Economic Paleontologists Meeting: American Association of Petroleum Geologists Bulletin, v. 60 , no. 8, p. 1390 .

Characteristics of the Roosevelt geothermal system; location and general geology; structure and petrology of the area; previous geological and geophysical studies of area; size and productivity of thermal anomaly; depth to reservoir.

BERGE, C. W., Crosby, G. W., and Lenzer, R. C., 1977, Exploration and evaluation of Roosevelt KGRA, Utah (abs.), in American Association of Petroleum Geologists and the Society of Economic Paleontologists Meeting: American Association of Petroleum Geologists Bulletin, v. 61 , no. 5 , p. $766-767$.

General geology and structure of area; geothermal investigation and evaluation of reservoir.

BERGE, C. W., Lund, J. W., Combs, J., and Anderson, D. N., 1981, Geothermal resources: American Association of Petroleum Geologists Bulletin, v. 65, no. 10, p. 2264-2273.

Methods of direct use development for geothermal energy across the United States including bathing uses, space heating, greenhouses and aquaculture projects, and industrial uses including a Utah ethanol plant; several electrical plants throughout the United States; geothermal well drilling activity; successful development wells from Utah and New Mexico-two at Cyrstal Hot Springs and two near Sandy, Utah; geothermal map of the United States; graphs showing geothermal well completions since 1975 and wells drilled during 1980; list of proposed geothermal electrical plants; list of estimated reservoir capacity and proposed power plant output for 14 hydrothermal areas including Roosevelt, Utah. 
BERRY, G. W., Grim, P. J., and Ikelman, J. A., 1980, Thermal springs list for the United States, National Oceanic and Atmospheric Administration key to geophysical records documentation, no. 12: U.S. Department of Commerce National Oceanic and Atmospheric Administration, Code D64, $59 \mathrm{p}$.

BEST, M. G., and Brimhall, W. H., 1974, Late Cenozoic alkalic basaltic magmas in the western Colorado Plateaus and the Basin and Range transition zone, U.S.A., and their bearing on mantle dynamics: Geological Society of America Bulletin, v. 85, no. 11, p. 1677-1690.

BEST, M. G., and Grant, S. K., in press, Stratigraphy of the volcanic Oligocene Needles Range group in southwestern Utah, chap. A, in Best, M. G., ed., Oligocene and Miocene volcanic rocks in the central Pioche-Marysvale igneous belt, western Utah and eastern Nevada: U.S. Geological Survey Professional Paper.

BEST, M. G., and Keith, J. D., 1983, Mid-Tertiary history of the central Pioche-Marysvale igneous belt, southwestern Utah, in Geologic excursions in volcanology: eastern Snake River Plain (Idaho) and southwestern Utah: Utah Geological and Mineral Survey Special Studies 61, p. 35-55.

BEST, M. G., McKee, E. H., and Damon, P. E., 1980 , Space-time-composition patterns of late Cenozoic mafic volcanism, southwestern Utah and adjoining areas: American Journal of Science, v. 180, p. 1035-1050.

BEST, M. G., Mehnert, H. H., Keith, J. D., and Naeser, C. $\mathbf{W}$., in press, Miocene magmatism and tectonism in and near the southern Wah Wah Mountains, southwestern Utah, chap. B, in, Best, M. G., ed., Oligocene and Miocene volcanic rocks in the central Pioche-Marysvale igneous belt, western Utah and eastern Nevada: U.S. Geological Survey Professional Paper.

BORDSEYE, H. S., 1969, Geothermal power resources in the Southwest, in Exploration for mineral resources-4th annual idea conference 1968: New Mexico Bureau of Mines and Mineral Resources Circular 101, p. 86-96.

BLACKWELL, D. D., 1983, Heat flow in the northern Basin and Range Province, in The role of heat in the development of energy and mineral resources in the northern Basin and Range Province: Geothermal Resources Council Special Report 13, p. 81-92.

BLACKWELL, D. D., and Chapman, D. S., 1977, Interpretation of geothermal gradient and heat flow data for Basin and Range geothermal systems: Geothermal Resources Council, Transactions, v. 1, p. 19-20.

BLAIR, K. C., 1980, Geothermal development of the Monroe KGRA, Utah, in Nielson, D. L., ed., Geothermal systems in central Utah: Geothermal Resources Council Annual Meeting, Salt Lake City, Utah, Guidebook to Field Trip, no. 7, p. 6-13.

Brief review of geology, gravity, resistivity surveys, thermal gradient measurements, seismicity, geochemistry, and geothermometry of Monroe KGRA; drilling of production test well and results of flow test.

BLAIR, K. C., Harrison, R., Sakashita, B., and Jones, A. H., 1980, The Monroe KGRA, in Commercial uses of geothermal heat: Geothermal Resources Council Special Report 9, p. 25-30.

Geological, geophysical, and geothermal data collected during previous studies of Monroe KGRA; general geology of area; purpose of study; 21 line-km of $100 \mathrm{~m}$ dipole-dipole mapping; graph showing two-dimensional resistivity model across Monroe mound; delineation of the Sevier fault and extent of the convective hydrothermal system from resistivity survey; graphs showing temperature profiles and thermal gradient profiles across the Monroe mound based on thermal gradient and test holes; procedures and problems encountered while drilling a $457 \mathrm{~m}$ production test well; graph showing temperature profiles in production well $\mathrm{MC} 3$; chemical analyses of waters in area; exploration and test program; conclusions.

BLAIR, K. C., and Owen, L. B., 1981, Evaluation of the production potential of the Crystal Hot Spring geothermal resource, north central Utah: Geothermal Resources Council, Transactions, v. 5, p. 319-323.

Location and ownership of Crystal Hot Springs; geology of the geothermal reservoir; estimates of maximum flow capacities and transmissivity of overlying sediments for thermal gradient hole SF-1; drilling equipment used to deepen SF-1; delineation of potential production zones based on a temperature log; drilling problems caused by circulation loss and slumping; equipment, procedures, and difficulties involved in drilling 1000 foot USP/TH-1 productivity test well; artesian flow test results from USP/TH-1; noncondensable gas concentration ranges at well head; well and reservoir parameter values; effects of producing wells on existing springs; predictions for long term reservoir performance.

BLAIR, K. C., and Owen, L. B., 1982, Direct utilization of geothermal resources field experiments at Monroe, Utah: final report, July 14, 1978 - July 13, 1981: National Technical Information Service Report, no. DOE/ET/27054-6, 231 p.; also, Terra Tek Report, no. TR 82-73, $218 \mathrm{p}$.

Objectives of study; location, general geology, and minimum geothermal reservoir temperatures of the Monroe geothermal system; exploration and production history; production plans, participants, and cost breakdown; dipole-dipole first separation apparent resistivity contour map of the Monroe area; graph of temperature profiles in thermal gradient and test holes; short and long term environmental impacts; private, city/county, and federal issues and permitting; production drilling and logging summary; thermal logging; methods and equipment used in hydraulic testing; predicted reservoir capacity; analysis of the application of Monroe heat to several proposed methods such as, space heating, mushroom farm- 
ing, milk pasteurization, prawn farming, and electrical generation; production system design; system economics.

BLISS, J. D., 1983, Utah; basic data for thermal springs and wells as recorded in GEOTHERM: U.S. Geological Survey Open-File Report 83-437, 385 p.

Data collected from GEOTHERM (a computerized information system that maintained data files on the geology, geochemistry, and hydrology of geothermal sites until 1983 and is presently off-line); sample file for Utah contains 643 records; appendices of indices for Utah springs and wells.

BODELL, J. M., 1981, Heat flow in the north-central Colorado Plateau: Salt Lake City, Utah, University of Utah, unpublished Masters thesis, $134 \mathrm{p}$.

BORTZ, L. C., 1983, Hydrocarbons in the northern Basin and Range, Nevada and Utah, in The role of heat in the development of energy and mineral resources in the northern Basin and Range Province: Geothermal Resources Council Special Report 13, p. 179-198.

BOWEN, R. G., 1975, Geothermal activity in 1974: Ore Bin, v. 37, no. 1, p. 9-10.

BOWERS, Dale, 1978, Potassium-argon age dating and petrology of the Mineral Mountains pluton, Utah: Salt Lake City, Utah, University of Utah, unpublished Masters thesis, $76 \mathrm{p}$.

BOWMAN, J. R., 1979, Stable isotope investigation of fluids and water-rock interaction in the Roosevelt Hot Springs thermal area, Utah: University of Utah, Department of Geology and Geophysics Topical Report, v. 77-10, $18 \mathrm{p}$.

Sample selection and preparation from drill cuttings, cold water springs and seeps, and geothermal wells; analytical techniques including carbonate oxygen and carbon extraction, silicates oxygen extraction, water oxygen extraction, water hydrogen extraction, and mass spectrometry; table showing isotopic analyses of geothermal carbonates; results of water and oxygen isotope analyses of regional spring waters and reservoir fluids; analysis of oxygen isotope composition of a whole rock sample; constituent quartz and potassium feldspar from well 14-2; estimate of minimum water-to-rock oxygen ratio in the geothermal system; reservoir permeability; conclusions; suggestions for future work.

BOWMAN, J. R., Evans, S. H., Jr., Hohmann, G. W., Nash, W. P., Reynolds, G. R., Sill, W. R., Ward, S. H., Christensen, O. D., Forsberg, W. L., Glenn, W. E., Killpack, T. J., Moore, J. N., Nielson, D. L., and Wright, P. M., 1980, Management assisstance for the development of hydrothermal energy in the Rocky Mountain/Basin and Range region: Earth Science Laboratory/University of Utah Research Institute Report, no. DOE/ET/28392-47, 41 p.

BOWMAN, J. R., Evans, S. H., Jr., and Nash, W. P., 1982, Oxygen isotope geochemistry of Quaternary rhyolite from the Mineral Mountains, Utah, U.S.A.: Earth Science Laboratory/University of Utah Research Institute Report, no. DOE/ID/12079-61, 23 p.

BOWMAN, J. R., and Rohrs, D. T., 1981, Light stable isotope studies of spring and thermal waters from the Roosevelt Hot Springs and Cove Fort/Sulphurdale thermal areas and of clay minerals from the Roosevelt Hot Springs thermal area: Earth Science Laboratory/University of Utah Research Institute Report, no. DOE/ID/12079-44, 36 p.

Direct sampling of waters involved in hydrothermal alteration; isotopic analysis of hydrogen, carbon, and oxygen, and thermal water interaction with the reservoir rock; general geology and structure of area; hot spring deposits and alteration products; origin of thermal waters; extent of isotopic exchange; oxygen and carbon isotopic composititon of calcite; tables of isotopic analyses of waters from Roosevelt.

BROOK, C. A., Mariner, R. H., Mabey, D. R., Swanson, J. R., Guffanti, M., and Muffler, L. J. P., 1979, Hydrothermal convection systems with reservoir temperatures greater than or equal to 90 degrees $\mathrm{C}$, in Muffler, L. J. P., ed., Assessment of geothermal resources of the United States-1978: U.S. Geological Survey Circular 790, p. 18-85.

Hydrothermal convection systems in the United States with mean reservoir temperatures greater than or equal to 90 degrees $C$, and depths less than or equal to $3 \mathrm{~km}$; methodology for determination of accessible resource base; use of geothermometers for temperature estimations; types of convection systems and their geologic settings; estimates of reservoir volumes; probability distributions of total thermal energy in identified systems; compares methodology used with that of U.S. Geological Survey Circular 726 (1975); undiscovered accessible resource base; distribution of undiscovered thermal energy between high and intermediate temperature categories; tables of hot-water hydrothermal convection systems greater than or equal to 150 degrees $\mathrm{C}$ (two areas in Utah); tables of hot-water hydrothermal convection systems between 90 and 150 degrees $C$ (five areas in Utah).

BROWN, D. R., 1982a, Geothermal energy development in Utah: Intersociety of Energy Conversion Engineering Conference, v. 5, p. 2179-2181.

BROWN, D. R., 1982b, Milford geothermal no. 1, Roosevelt Hot Springs KGRA: Sixth Annual Geothermal Conference and Workshop, Proceedings, p. 3.27-3.29.

Current role of Utah Power and Light Company in the geothermal development of Roosevelt Hot Springs; reservoir description; developmental procedures of well tapping; conversion of thermal waters into mechanical energy and subsequent reinjection into reservoir.

BROWN, D. R., 1983, Geothermal development activities: Roosevelt Hot Springs, Utah: Seventh Annual Geothermal Conference and Workshop, Proceedings, p. 2.13-2.19. 
BROWN, F. H., 1977, Attempt at paleomagnetic dating of opal, Roosevelt Hot Springs, KGRA: University of Utah, Department of Geology and Geophysics Report, no. 77-1, 13 p.

BROWN, F. H., and Nash, W. P., 1978, Geothermal potential of the eastern margin of the Basin and Range Province in Utah (abs.): U.S. Geological Survey Professional Paper 1100, p. 205-206.

Results of petrologic and geochronologic studies of Tertiary and Quaternary volcanic rocks in the eastern Basin and Range Province; brief description of normal faults in area; temperatures of thermal springs; heat source speculations.

BROWN, G. L., and Mansure, A. J., 1981, A forecast of geothermal drilling activity: Geothermal Resources Council, Transactions, v. 5, p. 225-228.

BROWN, R. P., 1975, A regional gravity survey of the Sanpete-Sevier Valley and adjacent areas in Utah: Salt Lake City, Utah, University of Utah, unpublished Masters thesis, $72 \mathrm{p}$.

BROWN, R. P., and Cook, K. L., 1982, A regional gravity survey of the Sanpete-Sevier Valleys and adjacent areas in Utah, in Nielson, D. L., ed., Overthrust belt of Utah, 1982 symposium and field conference: Utah Geological Association Publication 10, p. 121-135.

BRUMBAUGH, W. D., 1978, Gravity survey of the Cove Fort-Sulphurdale KGRA and the north Mineral Mountains area, Millard and Beaver Counties, Utah: Salt Lake City, Utah, University of Utah, unpublished Masters thesis, $131 \mathrm{p}$.

Location and geography of survey area; prior investigations; geology, Tertiary volcanics, and general geophysics (gravity, magnetics, and seismic); 671 gravity stations over area of 1300 square $\mathrm{km}$; two orthogonal gravity profiles traversing area; terrain corrected Bouguer gravity anomaly map with $1 \mathrm{mgal}$ interval; isometric three-dimensional gravity anomaly surface; instrumentation, field procedures, and data reduction methods; data error analysis; regional gravity patterns and observed values on terrain-corrected Bouguer gravity anomaly map; Cove Fort-Sulphurdale gravity patterns; anomaly separation techniques, gravity profile, and geologic interpretation techniques; table showing location and wet bulk density of rock samples from area.

BRUMBAUGH, W. D., and Cook, K. L., 1977, Gravity survey of the Cove Fort-Sulphurdale KGRA and the north Mineral Mountains area, Millard and Beaver Counties, Utah: University of Utah, Department of Geology and Geophysics Report, no. 77-4, 131 p.

See Brumbaugh (1978).

BRYAN, Kirk, 1919, Classification of springs: Journal of Geology, v. 27, p. 522-561.

BRYANT, N. L., 1977, Hydrothermal alteration at Roosevelt Hot Springs KRGA - DDH 1976-1: Salt Lake City,
Utah, University of Utah, unpublished Masters thesis, $87 \mathrm{p}$.

See Bryant and Parry (1977).

BRYANT, N. L., and Parry, W. T., 1977, Hydrothermal alteration at Roosevelt Hot Springs KGRA - DDH 1976-1: University of Utah, Department of Geology and Geophysics Technical Report, v. 77-5, 87 p.

Use of petrographic, X-ray, and chemical methods to characterize systematic changes in chemistry and mineralogy in a 200 foot drill core; alteration zones and chemical analyses of zones; model proposed to account for zones; estimation of heat flow contributions from hydrothermal alteration; geology and structure of Roosevelt Hot Springs; lithologic core.

BUCHER, R. L., 1971, Crustal and upper mantle structure beneath the Colorado Plateau and Basin and Range Provinces as determined from Rayleigh-wave dispersion: Salt Lake City, Utah, University of Utah, unpublished Ph.D. thesis, $106 \mathrm{p}$.

BURBANK City Public Service Department, 1977, Sitespecific analysis of hybrid geothermal/fossil power plants, v. 1, Roosevelt Hot Springs KGRA: National Technical Information Service Report, no. SAN-1311-T2, 73 p.

BUTLER, D. R., 1975, Geothermal energy on the Pacific Coast, in Weaver, D. W., and others, eds., Paleogene symposium and selected technical papers; conference on future energy horizons of the Pacific Coast: American Association of Petroleum Geologists Pacific Section, p. 99-120.

BUTZ, J. R., 1980, A case study of two-phase flow at the Roosevelt Hot Springs, Utah KGRA: Geothermal Resources Council, Transactions, v. 4, p. 439-442.

Case study of two-phase (steam/water) flow in well, Utah State 14-2 to obtain pressure and temperature logs as a function of depth; field test procedures and equipment performance problems; data reduction procedures; analysis of data; comparison of test data with a two-phase flow predictive computer model; comparison of maximum sustainable flow rate from a reservoir as a function of casing diameter; calculation of a Productivity Index capable of producing input flow rate under given conditions; results and analysis of tests and model deviations.

BUTZ, J. R., and Plooster, M., 1979, Subsurface investigations at the Roosevelt KGRA, Utah, well 14-2: Earth Science Laboratory/University of Utah Research Institute Open-File Report, no. UT/RHS/DRI-2, 73 p.

Final report of DRI flow test; predictions for well production capacities; computer modeling of data for indication of maximum flow rates; temperature and pressure logs.

CADY, C. C., 1983, Hydrothermal alteration in the Corral Canyon shear zone, Mineral Mountains, Utah: with inferences for shearing: Salt Lake City, Utah, University of Utah, unpublished Masters thesis, $92 \mathrm{p}$. 
CALKINS, W. G., 1969, Magnetic and gravity study of Desert Mountain, Juab County, Utah: Salt Lake City, Utah, University of Utah, unpublished Masters thesis, $64 \mathrm{p}$.

CALlaGHAN, Eugene, and Thomas, H. E., 1939, Manganese in a thermal spring in west-central Utah: Economic Geology, v. 34, no. 8, p. 905-920.

Commercially exploited manganese ore from Abraham Hot Springs; surface features of Abraham Hot Springs area; general geology of the area; temperature ranges and discharge rates of waters issuing from the hot springs dome; table showing analyses of waters; deposits and alteration from the springs; table showing analyses of manganese ore from Abraham Hot Springs; speculation on the origin of minerals in Abraham Hot Springs deposits; speculation on origin of hot spring waters; average temperature gradient for a dozen wells in the region; comparison with other manganese deposits; total yield of manganese from Abraham Hot Springs.

CALlender, J. F., Swanberg, C. A., Morgan, P., Stoyer, C. H., and Witcher, J. C., 1977, Appraisal study of the geothermal resources of Arizona and adjacent areas in New Mexico and Utah and their value for desalination and other uses: New Mexico Energy Institute Report, no. NMEI-6-1, $99 \mathrm{p}$.

CAMPBELl, D. L., Cunningham, C. G., Steven, T. A., Rowley, P. D., Glassgold, L. B., and Anderson, J. J., 1984, Aeromagnetic map on a geologic base map of the Tushar Mountains and adjoining areas, Marysvale volcanic field, Utah: U.S. Geological Survey Miscellaneous Investigations Series Map I-1430D, scale 1:50,000.

CAMPBELL, D. L., and Flanigan, V. J., 1982, Geophysical measurements in the Beaver Basin, west-central Utah: Part II-Resistivity, IP, and seismic investigations: U.S. Geological Survey Open-File Report 82-420, $44 \mathrm{p}$.

CAPUANO, R. M., and Bamford, R. W., 1978, Initial investigation of soil mercury geochemistry as an aid to drill site selection in geothermal systems: Earth Science Laboratory/University of Utah Research Institute Report, no. IDO/78-1701.b.3.3, 32 p.

Soil mercury geochemistry from past studies at Roosevelt; objective of study; geology of study area; geologic structures controlling Roosevelt geothermal system; map showing mercury traverses and well locations at Roosevelt; procedures for soil sampling and analysis; precision of measurements; geochemical background and threshold calculations; results and implications of mercury concentrations in soils; proximity of mercury anomalies to known geologic structures.

CAPUANO, R. M., and Cole, D. R., 1982, Fluid-mineral equilibria in a hydrothermal system, Roosevelt Hot Springs, Utah: Geochimica et Cosmochimica Acta, v. 46, no. 8, p. 1353-1364; also, 1981, (abs.) Geological Society of America Abstracts with Programs, v. 13, no. 7, p. 422.
Explores relationship between chemical and physical processes that occur during hydrothermal alteration in a geothermal system; defines an alteration pattern characteristic of the reservoir rock; evaluates and compares mineral equilibra in deep reservior fluid with the alteration mineralogy of the reservoir rock; calculation of deep reservior fluid chemistry; discusses geology and hydrothermal alteration.

CARLSTON, K. J., 1982, Electric field ratio telliric survey of the Roosevelt Hot Springs, Utah: Earth Science Laboratory/University of Utah Research Institute Report, no. DOE/ET/28392-26, 33 p.; also, Salt Lake City, Utah, University of Utah, unpublished Masters thesis, $103 \mathrm{p}$.

Previous geologic studies and geologic setting of Roosevelt Hot Springs region; field instruments and measurements; map showing locations of four measured profiles; qualitative and quantitative interpretations of data; comparisons of field data profiles with calculated relative electric field curves and with the models derived from Schlumberger resistivity data; comparison of field data with calculated curves resulting from models derived from CSAMT data; comparison of field data with curves resulting from models derived from dipole-dipole data; conclusions.

CARPENTER, C. H., and Young, R. A., 1962, Records of selected wells and springs, chemical analyses of ground water, water level measurements of selected wells, selected drillers' logs of wells, and logs of test holes, central Sevier Valley, Sanpete, Sevier, and Piute Counties, Utah: U.S. Geological Survey Open-File Report 62-26, $29 \mathrm{p}$.

CARPENTER, C. H., and Young, R. A., 1963, Records of selected wells and springs, chemical analyses of ground water, water level measurements of selected wells, selected drillers' logs of wells, and logs of test holes, central Sevier Valley, Sanpete, Sevier, and Piute Counties, Utah: U.S. Geological Survey Open-File Report 63-14, $29 \mathrm{p}$.

CARPENTER, Everett, 1913, Ground water in Box Elder and Tooele Counties, Utah: U.S. Geological Survey Water-Supply Paper 333, 87 p.

CARRIER, D. L., 1979, Gravity and heat flow studies at Twin Peaks: an area of late Tertiary silicic volcanism in Millard County, Utah: Salt Lake City, Utah, University of Utah, unpublished Masters thesis, $120 \mathrm{p}$.

CARRIER, D. L., and Chapman, D. S., 1979, Gravity and heat flow studies in the Cove Creek Dome area, Utah (abs.): Geological Society of America Abstracts with Programs, v. 11, no. 6, p. 268.

Gravity and heat flow studies in young rhyolites and basalts; 350 new gravity stations along three profiles; pronounced 15 mgal gravity low; range of terraincorrected Bouguer gravity values; average heat flow results; interpretation of a regional gravity pattern. 
CARRIER, D. L., and Chapman, D. S., 1980, Gravity and thermal models of the Twin Peaks magma system, westcentral Utah: Geothermal Resources Council, Transactions, v. 4, p. 17-20.

CARSON, C. C., and Livesay, B. J., 1981, Well descriptions for geothermal drilling: Geothermal Resources Council, Transactions, v. 5, p. 229-232.

CARTER, J. A., 1978, Regional gravity and aeromagnetic surveys of the Mineral Mountains and vicinity, Millard and Beaver Counties, Utah: Salt Lake City, Utah, University of Utah, unpublished Masters thesis, $178 \mathrm{p}$.

CARTER, J. A., and Cook, K. L., 1978, Regional gravity and aeromagnetic surveys of the Mineral Mountains and vicinity, Millard and Beaver Counties, Utah: University of Utah, Department of Geology and Geophysics Final Report, v. 77-11, 178 p.

CARTER, J. A., Cook, K. L., Brumbaugh, W. D., Ward, S. H., Crebs, T. J., and Thangsuphanich, I., 1977, Regional aeromagnetic and gravity surveys of the Roosevelt Hot Springs and Cove Fort-Sulphurdale KGRAs, Utah (abs.): Geophysics, v. 42, no. 7, p. 1498.

Aeromagnetic map of Mineral Mountains digitized and reduced to the pole and downward continued; downward continued map and a pseudomagnetic map used as base maps for polynomial fitting and application of several linear filters; anomaly analysis procedures and results; description of Mineral Range aeromagnetic map.

CASE, R. W., 1977, A regional gravity survey of the Sevier Lake area, Millard and Beaver Counties, Utah: Salt Lake City, Utah, University of Utah, unpublished Masters thesis, $95 \mathrm{p}$.

CASKEY, C. F., and Shuey, R. T., 1975, Mid-Tertiary volcanic stratigraphy, Sevier-Cove Fort area, central Utah: Utah Geology, v. 2, no. 1, p. 17-25.

CASSEL, T. A. V., Edelstein, R. H., and Blair, P. D., 1978, Geothermal investment analysis with site-specific applications to Roosevelt Hot Springs and Cove FortSulphurdale, Utah: National Technical Information Service Report, no. DOE/ET/28486-T1, 194 p.

Study to analyze and model the investment behavior of companies involved in the development of hydrothermal electric power facilities; investment model as a means to predict capital investments in the development of hydrothermal well fields for electric power production; investment considerations for the resource producing company, electric utility company, and commercial financing firms; cash flow model to probabilistically estimate the financial attributes of site specific ventures; simulation model which estimates probabilistic distribution for gain, loss, or payback time at a given resource time; application of investment model developed in this report to Roosevelt and Cove Fort KGRAs; tables of resource characteristics, developmental data, and cumulative probability graphs of the net present value estimated for a specific level of power development.
CASSEL, T. A. V., Edelstein, R. H., Blair, P. D., and Amundsen, C. B., 1979, Geothermal investment and policy analysis with evaluation of California and Utah resources area: National Technical Information Service Report, no. DOE/RA/4713-1, 160 p.

CHAPMAN, D. S., Blackwell, D. D., Parry, W. T., Sill, W. R., Ward, S. H., and Whelan, J. A., 1978, Regional heat flow and geochemical studies in southwest Utah: University of Utah, Department of Geology and Geophysics Final Report, v. 2, contract no. 14-08-0001-G-341, 118 p.

CHAPMAN, D. S., Clement, M. D., and Mase, C. W., 1981, Thermal regime of the Escalante Desert, Utah, with an analysis of the Newcastle geothermal system: Journal of Geophysical Research, v. 86, no. B12, p. 11,735-11,746.

Location, stratigraphy, and general geology of the Escalante Desert, Utah; procedures and equipment used to measure heat flow; graph of temperature-depth profiles; geologic map of the Escalante Desert region; drilling problems and down-hole temperatures; determination of thermal conductivities; table showing basic data collected for Escalante Desert heat flow; surface characteristics and heat flow in the Newcastle geothermal system; graph of temperature-depth profiles and heat flow map for the Newcastle geothermal system.

CHAPMAN, D. S., and Harrison, R., 1978, Monroe, Utah, hydrothermal system: results from drilling of test wells MC1 and MC2: Earth Science Laboratory/University of Utah Research Institute Report, no. IDO/76-1601-77-16, $26 \mathrm{p}$.

Test wells used to obtain structural information on dip of Sevier fault and temperature information below 300 feet; cased wells to be used for monitoring; lithologic logs; heat flow and temperature cross-sections; gravity and magnetic interpretation; dipole-dipole resistivity pseudosection.

CHAPMAN, D. S., and Keho, T., 1982, A thermal resistance method for computing surface heat flow and subsurface temperatures with application to the Unita Basin of northeastern Utah: Earth Science Laboratory/University of Utah Research Institute Report, no. DOE/ID/12079-79, 36 p.

CHAPMAN, D. S., Kilty, K. T., and Mase, C. W., 1978a, Characteristics of a fault controlled geothermal system (abs.): EOS Transactions, American Geophysical Union, v. 59, no. 12, p. 1201.

Study of Monroe, Utah geothermal system (located along the Sevier fault) to determine size, geometry, heat loss, and fluid flow patterns for the hydrothermal system; use of $100 \mathrm{~m}$ dipole-dipole first separation apparent resistivity and total magnetic intensity maps to delineate fault zone and zone of low resistivity; two profiles of thermal gradients in 11 drill holes; heat flow and total heat loss of geothermal system; modeling of subsurface temperature field using forced convection up a dipping permeable fracture zone. 
CHAPMAN, D. S., Kilty, K. T., and Mase, C. W., 1978b, Temperatures and their dependence on groundwater flow in shallow geothermal systems: Geothermal Resources Council, Transactions, v. 2, p. 79-82.

CHILDS, F. W., Jones, K. W., Nelson, L. B., Strawn, J. A., and Tucker, M. K., 1980, Progress in direct heat applications projects: Geothermal Resources Council, Transactions, v. 4, p. 549-552.

CHRISTENSEN, O. D., 1982, Multielement geochemistry of three geothermal wells, Cove Fort-Sulphurdale geothermal area, Utah: Earth Science Laboratory/University of Utah Research Institute Report, no. DOE/ID/12079-80, $51 \mathrm{p}$.

Interpretation of the relationship of drill cutting geochemistry to sequential hydrothermal events; geologic setting; methods of sample analysis; elemental distribution populations; figures of elemental distribution, sulfide distribution, and lithology for three wells.

CHRISTENSEN, O. D., Capuano, R. A., and Moore, J. N., 1983, Trace-element distribution in an active hydrothermal system, Roosevelt Hot Springs thermal area, Utah: Journal of Volcanology and Geothermal Research, $v$. 16 , no. $1 / 2$, p. $99-129$.

Occurrence of trace amounts of base and precious metals in hot spring deposits and hydrothermally altered rocks; scope of study; general geology of Roosevelt Hot Springs area; table showing chemistry of thermal waters; mineral content of hydrothermal alteration and hot spring deposits at Roosevelt; hydrothermal mineral assemblages at depth; sample collection procedures; analytical techniques and results; graphs showing cumulative frequency distribution on log-probability coordinates of $\mathrm{As}, \mathrm{Hg}$, and $\mathrm{Li}$ contents of $30 \mathrm{~m}$ interval drill hole cutting samples; five suites of trace-element enrichments at Roosevelt; table showing chemistry of surface samples; soil geochemistry results; concentrations of $\mathrm{As}, \mathrm{Li}, \mathrm{Hg}$, and $\mathrm{Sb}$ in drill cuttings; distribution of $\mathrm{As}, \mathrm{Sb}, \mathrm{Li}, \mathrm{Hg}, \mathrm{Fe}$, and $\mathrm{Mn}$; proposed geothermal system model; significance of trace-element geochemical distributions in geothermal exploration.

CHRISTENSEN, O. D., Moore, J. N., and Capuano, R. M., 1980, Trace element geochemical zoning in the Roosevelt Hot Springs thermal area, Utah: Geothermal Resources Council, Transactions, v. 4, p. 149-152.

Lithology, structure, and geologic setting of Roosevelt Hot Springs; geochemistry of geothermal fluids; geochemical section across the geothermal system based on temperatures and distribution of $\mathrm{As}, \mathrm{Hg}$, and $\mathrm{Li}$ in two producing wells and one nonproducing drill hole; comparison of trace element distribution patterns and application of patterns to temperature configurations and fluid flow; trace element content of soils and minerals.

CHRISTIANSEN, R. L., and Lipman, P. W., 1972, Cenozoic volcanism and plate tectonic evolution of the western United States; II. Late Cenozoic: Philosophical
Transactions of the Royal Society of London, s. A271, p. 249-284.

CHU, J. J., 1980, Induced polarization data at Roosevelt Hot Springs geothermal area, Utah: Salt Lake City, Utah, University of Utah, unpublished Masters thesis, 85 p.

Purpose of study; similar studies and results; location of Roosevelt Hot Springs KGRA; sample preparation and experimental procedures for laboratory research; laboratory data collected at 25,50 , and 75 degrees $C$ on hydrothermally altered rocks; interpretations from ten laboratory samples; table showing parameter values of effective porosity, cation exchange capacity, and clay and pyrite content for six core samples; resistivity and the effects of temperature; two induced polarization field traverses across study area; interpretation of field data; apparent resistivity pseudosections for high and low frequencies; phase extrapolation; removal of inductive coupling using the double Cole-Cole model; conclusions.

CHU, J. J., Sill, W. R., and Ward, S. H., 1979, Inducedpolarization measurements at Roosevelt Hot Springs thermal area, Utah: Earth Science Laboratory/University of Utah Research Institute Report, no. IDO/78-1701.a.2.4.1, 34 p.; also, 1980, (abs.), Geophysics, v. 45 , no. 3 , p. 587.

See Chu (1980).

CIANCANELLI, E. V., 1977, Geology and geophysics of the Roosevelt geothermal field, Utah: O'Brien-Thermal Power-AMAX application for an ERDA loan guarantee, $44 \mathrm{p}$.

Location and exploration history of Roosevelt Hot Springs geothermal area; regional and local geology; Mineral Mountains stratigraphy; Tertiary volcanic section, petrology, and age dates; regional and local structure; description of thermal manifestations in the Roosevelt area; thermal gradient trends and production capabilities for seven thermal wells; hydrothermal alteration; speculations on heat source; several chemically distinct water types from area; table showing selected Roosevelt KGRA water analyses; temperature range from geothermometer studies; Bouguer gravity anomaly map and discussion of gravity patterns; aeromagnetic intensity residual anomaly map and trends; passive seismic and electrical surveys; temperature gradients; geology of section 16; drilling, sampling, lithology, alteration, and reservoir pressure estimates of well 72-16.

CIANCANELLI, E. V., and Corman, F. D., 1978, Geology of the Roosevelt geothermal field, Beaver County, Utah: Canadian Geothermal Resources Association Newsletter, no. 2, p. 3.

See Ciancanelli (1977).

CLARK, A. L., Calkins, J. A., Tongiorgi, E., and Stefanelli, E., 1976, A report on the international geothermal information exchange program, 1974-1975: United Na- 
tions symposium on the development and use of geothermal resources, 2d, San Francisco, California, 1975, Proceedings, v. 1, p. 67-100.

CLARK, E. E., 1977, Late Cenozoic volcanic and tectonic activity along the easte-n margin of the Great Basin, in the proximity of Cove Fort, Utah: Brigham Young University Geology Studies, v. 24, pt. 1, p. 87-114.

CLARKE, F. W., 1914, Water analyses from the laboratory of the United States Geological Survey: U.S. Geological Survey Water-Supply Paper 364, $40 \mathrm{p}$.

CLEARY, M. D., 1978, Description and interpretation of geothermometry as applied to Utah spring and well waters: Salt Lake City, Utah, University of Utah, unpublished Masters thesis, $73 \mathrm{p}$.

CLEMENT, M. D., 1981, Heat flow and geothermal assessment of the Escalante Desert, part of the Oligocene to Miocene volcanic belt in southwestern Utah: Salt Lake City, Utah, University of Utah, unpublished Masters thesis, $118 \mathrm{p}$.

See Clement and Chapman (1981).

CLEMENT, M. D., and Chapman, D. S., 1981, Heat flow and geothermal assessment of the Escalante Desert, southwestern Utah, with emphasis on the Newcastle KGRA: Earth Science Laboratory/University of Utah Research Institute Report, no. DOE/ID/12079-28, $118 \mathrm{p}$.

Assessment of thermal regime of Escalante Desert using 25 recently acquired heat flow values to define the magnitude of regional heat flow; geologic setting; heat flow measurements including temperature-depth profiles; heat flow determinations of Newcastle geothermal system; appendices of principal facts for heat flow data and Escalante Desert hand sample data.

COLE, D. R., 1981, Isotopic and ion chemistry of waters in the east shore area, northern Utah: Geothermal Resources Council, Transactions, v. 5, p. 63-66.

COLE, D. R., 1982, Chemical and sulfur isotope variations in a thermal spring system sampled through time: Geothermal Resources Council, Transactions, v. 6, p. 81-84.

Theory of isotope variations in thermal waters; purpose of study; location and general geology of the Warm Springs fault geothermal system; relation of thermal waters to local and regional faults; trends of chemical variations in spring waters with time; correlation of surface temperatures with chemical variations; origin of sulfate in thermal waters; theories on generation of $\mathrm{H}_{2} \mathrm{~S}$ in natural solutions; table showing comparison of sulfur isotopic geothermometer estimates with cation and quartz geothermometer temperatures; conclusions.

COLE, D. R., 1983, Chemical and isotopic investigation of warm springs associated with normal faults in Utah: Journal of Volcanology and Geothermal Research, v. 16 , no. $1 / 2$, p. $65-98$.
Investigation of chemical and isotopic models for effectively predicting subsurface chemical and physical conditions characteristic of low-to moderate-temperature thermal systems; sample preparation and analysis; chart showing summary of spring locations, water and rock types, and discharge rates; diagrams showing relative amounts of major anions and cations in cold and thermal water samples; chart showing chemical and isotopic compositions for Utah warm springs; table of geothermometer temperature estimates for spring waters; ranges of calculated subsurface temperatures; results of calculations to determine reaction states of aqueous solutions with respect to silicates, carbonates, sulfates, and oxides; mineral saturation trends for Utah thermal waters; mineral saturation estimates for mixing models; isotopic compositions of Utah thermal springs; age determinations for Thermo and Red Hill ground waters; conclusions.

COMBS, Jim, Berge, C. W., Lund, J. W., and Anderson, D. N., 1982, Developments in geothermal resources in 1981: American Association of Petroleum Geologists Bulletin, v. 66 , no. 11 , p. 2489-2499.

A reduction in the 1981-82 budget for the United States Department of Energy Division of Geothermal Energy will encourage private industry to participate in geothermal energy development; five major geothermal direct heating projects under construction; several agribusiness related projects using geothermal energy underway; construction continued on six electrical power generation plants that are scheduled for operation between 1982 and 1984; one electrical power facility (1.6 MWe) at Roosevelt Hot Springs, Utah became operational in 1981; facilities and future plans for the Roosevelt unit; geothermal drilling activity for exploration and development wells.

COMBS, Jim, Berge, C. W., Lund, J. W., Anderson, D. N., and Parmentier, P. P., 1983, Developments in geothermal resources in 1982: Geothermal Resources Council Bulletin, v. 12, no. 11, p. 4-13; also, Geothermal Resources Council Bulletin, v. 12, no. 11, p. 4-13.

Drilling statistics on 1982 geothermal wells; map showing geothermal drilling in the western United States in 1982; chart showing 1982 summary of geothermal drilling in the western United States by operator; significant technical developments achieved; direct use development in several geothermal areas; Phillips Petroleum Company wellhead flow capacity tests at Roosevelt Hot Springs KGRA; Roosevelt Hot Springs geothermal power plant constructed by Utah Power and Light; exploratory drilling projects conducted by Phillips Petroleum in Utah.

CONDIE, K. C., 1960, Petrogenesis of the Mineral Range pluton, southwest Utah: Salt Lake City, Utah, University of Utah, unpublished Masters thesis, $92 \mathrm{p}$. 
CONDIE, K. C., and Barsky, C. K., 1970, The origin of Srdepleted basalts (abs.): EOS Transactions, American Geophysical Union, v. 51, no. 4, p. 443.

CONDIE, K. C., and Barsky, C. K., 1972, Origin of Quaternary basalts from the Black Rock Desert region, Utah: Geological Society of America Bulletin, v. 83, no. 2, p. 333-352.

CONRAD, O. G., 1969, Tertiary volcanic rocks of Needles Range, western Utah: Utah Geological and Mineral Survey Special Studies 29, 28 p.

COOK, E. F., 1957, Geology of the Pine Valley Mountains: Utah Geological and Mineral Survey Bulletin 58, $119 \mathrm{p}$.

COOK, K. L., Adhidjaja, J. I., and Gabbert, S. C., 1981, Complete Bouguer gravity anomaly and generalized geology map of Richfield $1 \times 2$ degree quadrangle, Utah: Utah Geological and Mineral Survey Map 59, scale $1: 250,000$.

COOK, K. L., and Carter, J. A., 1978, Precision leveling and gravity studies at Roosevelt Hot Springs KGRA, Utah: University of Utah, Department of Geology and Geophysics Final Report, v. 77-9, 56 p.

Map showing location of Roosevelt Hot Springs and leveling lines; objective of precision leveling and gravity surveys; procedures used in leveling surveys 1 and 2; table showing elevations of survey monuments; instruments, procedures, and problems encountered in running two precision-control surveys in area; periodic gravity readings taken with LaCoste and Romberg model "G" gravity meters at Phillips Petroleum Company's well 54-3; procedures and complications encountered with readings; four regional precision gravity surveys-instruments used, procedures, data reduction, and results; tables showing observed precision gravity values for surveys 1 through 4; discussion of results; summary, conclusions, and recommendations.

COOK, K. L., Halliday, M. E., Cunningham, C. G., Steven, T. A., Rowley, P. D., Glassgold, L. B., Anderson, J. J., and Coles, L. L., 1984, Complete Bouguer gravity anomaly map on a geologic base map of the Tushar Mountains and adjoining areas, Marysvale volcanic field, Utah: U.S. Geological Survey Miscellaneous Investigations Series Map I-1430C, scale 1:50,000.

COOK, K. L., Montgomery, J. R., Smith, J. T., and Gray, E. F., 1975, Simple Bouguer gravity anomaly map of Utah: Utah Geological and Mineral Survey Map 37, scale $1: 1,000,000$.

COOK, K. L., Serpa, L. F., and Pe, W., 1980, Detailed gravity and aeromagnetic survey of the Cove FortSulphurdale KGRA and vicinity, Millard and Beaver counties, Utah: Earth Science Laboratory/University of Utah Research Institute Report, no. DOE/ET/28392-30, 88 p.

Maps showing location of surveys and topography of surrounding area; prior geological and geophysical studies; purpose of study; stratigraphy, structure, petrology, and general geologic map of area; gravity, magnetic, and seismic descriptions of area; data collection, compilation, and reduction for gravity and aeromagnetic surveys; terrain-corrected Bouguer gravity anomaly map of Cove Fort-Sulphurdale region; map showing aeromagnetic field intensity residual map of Cove FortSulphurdale region; graph showing plot of the root-mean square values of the difference between the observed and the least-squares best-fit polynomial magnetic values versus polynomial order for digitized data; second-order polynomial surface of aeromagnetic field intensity residual data for the study area; bulk density and magnetic susceptibility measurements on rock samples; interpretation of gravity map; four east-west gravity profiles, procedures for modeling, and interpretations; interpretation of aeromagnetic maps; five magnetic profiles, modeling procedures, and interpretations; conclusions of study; appendices showing wet bulk densities of rock samples, magnetic susceptibilities, drill hole logs, and principal facts and designations of gravity stations.

COOK, K. L., Serpa, L. F., Pe, W., and Brumbaugh, W., 1980, Detailed gravity survey of the Cove FortSulphurdale KGRA and vicinity, Millard and Beaver Counties, Utah (abs.): Geological Society of America Abstracts with Programs, v. 12, no. 6, p. 270.

Detailed gravity survey in the Cove Fort-Sulphurdale KGRA with 750 stations; gravity contour patterns on the compiled terrain-corrected Bouguer gravity anomaly map; interpretation of data; results of four east-west gravity profiles.

CORDOVA, R. M., and Mower, R. W., 1976, Fracturing and subsidence of the land surface caused by the withdrawal of ground water in the Milford area, Utah: U.S. Geological Survey Journal of Research, v. 4, no. 5, p. 505-510; also, 1975, (abs.), Geological Society of America Abstracts with Programs, v. 7, no. 7, p. 1039.

CORWIN, R. F., and Hoover, D. B., 1979, The selfpotential method in geothermal exploration: Geophysics, v. 44 , no. 2 , p. $226-245$.

COSTAIN, J. K., 1973, Heat flow at Spor Mountain, Jordan Valley, Bingham, and La Sal, Utah: Journal of Geophysical Research, v. 78 , no. 35 , p. 8687-8698.

COSTAIN, J. K., and Wright, P. M., 1969, Heat flow and precision temperature measurements in boreholes: Society of Professional Well Log Analysts Logging Symposium, 10th Annual, Houston, Texas, 1969, Transactions, $121 \mathrm{p}$.

CREBS, T. J., 1975, Gravity and ground magnetic surveys of the central Mineral Mountains, Utah: Salt Lake City, Utah, University of Utah, unpublished Masters thesis, $129 \mathrm{p}$.

CREBS, T. J., and Cook, K. L., 1976, Gravity and ground magnetic surveys of the central Mineral Mountains, 
Utah: University of Utah, Department of Geology and Geophysics Final Report, v. 6, 129 p.

CREBS, T. J., Cook, K. L., Thangsuphanich, I., Brumbaugh, W. D., and Ward, S. H., 1977, Gravity and magnetic surveys of the Mineral Mountains area, Utah, including the Roosevelt Hot Springs KGRA (abs.): Geophysics, v. 42, no. 1, p. 145.

Over 1,000 gravity stations and 800 ground magnetic stations established across the Mineral Mountains area; gravity features and results of profiles; procedures used to digitize and filter gravity data; discussion of trends in the Mineral Range aeromagnetic map.

CRECRAFT, H. R., 1984, Silicic volcanism at Twin Peaks, west-central Utah; geology and petrology, chemical and physical evolution, oxygen and hydrogen isotope studies: Salt Lake City, Utah, University of Utah, unpublished Ph.D. thesis, 225 p.

CRECRAFT, H. R., Nash, W. P., and Evans, S. H., Jr., 1980a, Chemical and thermal evolution of the Twin Peaks magma system, west central Utah: Geothermal Resources Council, Transactions, v. 4, p. 117-120.

CRECRAFT, H. R., Nash, W. P., and Evans, S. H., Jr., 1980b, Petrology, geochronology, and chemical evolution of the Twin Peaks rhyolite domes, Utah: Earth Science Laboratory/University of Utah Research Institute Report, no. DOE/ID/12079-4, 211 p.

CRECRAFT, H. R., Nash, W. P., and Evans, S. H., Jr., 1981, Late Cenozoic volcanism at Twin Peaks, Utah: geology and petrology: Journal of Geophysical Research, v. 86 , no. B11, p. 10,303-10,320.

CREMER, G. M., compiler, 1980, Hot dry rock geothermal energy development program: Los Alamos National Laboratory Report, no. LA-8855-HDR, 211 p.

CRITTENDEN, M. D., Jr., 1951, Manganese deposits of western Utah: U.S. Geological Survey Bulletin 979-A, $62 \mathrm{p}$.

CROOK, J. K., 1899, The mineral waters of the United States and their therapeutic uses: New York and Philadelphia, Lea Brothers and Company, $588 \mathrm{p}$.

CROSBY, G. W., 1973, Regional structure in southwestern Utah, in Hintze, L. F., and Whelan, J. A., eds., Geology of the Milford area: Utah Geological Association, Publication 3, p. 27-33.

CROSSON, R. S., 1964, Regional gravity survey of parts of western Millard and Juab Counties, Utah: Salt Lake City, Utah, University of Utah, unpublished Masters thesis, $32 \mathrm{p}$.

CROWLEY, C. J., 1977, Developments in Four Corners intermountain area in 1976: American Association of $\mathrm{Pe}$ troleum Geologists Bulletin, v. 61, no. 8, p. 1204-1207.

Geologic provinces included in the study; exploration drilling and significant discoveries including a Cisco Springs, Utah field extension; infill drilling in the Utah
Aneth oil field; areas of geothermal potential outlined through exploratory drilling; lease and drilling activity in Summit and Rich Counties, Utah.

CROWLEY, C. J., 1978, Developments in Four Corners intermountain area in 1977: American Association of $\mathrm{Pe}$ troleum Geologists Bulletin, v. 62, no. 8, p. 1360-1363.

Report area and geologic provinces; wells added from 1976 to 1977; three significant Utah wells including one producer in Rich County and two discoveries southwest of Pineview field; development drilling in the Four Corners area; expectations of increased geothermal activity in Utah and western New Mexico; plans for $52 \mathrm{MWe}$ geothermal power plant at Roosevelt Hot Springs, Utah; table showing 1977 drilling completion summary for Four Corners intermountain area; list of significant geothermal discoveries in 1977 in the study area.

CUNNINGHAM, C. G., and Steven, T. A., 1979a, Geologic map of the Monroe SW quadrangle, west-central Utah: U.S. Geological Survey Miscellaneous Field Studies Map MF-1140, scale 1:24,000.

CUNNINGHAM, C. G., and Steven, T. A., 1979b, Mount Belknap and Red Hills calderas and associated rocks, Marysvale volcanic field, west-central Utah: U.S. Geological Survey Bulletin 1468, 40 p.

CUNNINGHAM, C. G., Steven, T. A., Campbell, D. L., Naeser, C. W., Pitkin, J. A., and Duval, J. S., 1984, Multiple episodes of igneous activity, mineralization, and alteration in the western Tushar Mountains, Utah, in Steven, T. A., ed., Igneous activity and related ore deposits in the western and southern Tushar Mountains, Marysvale volcanic field, west-central Utah: U.S. Geological Survey Professional Paper 1299A, p. 1-21.

CUNNINGHAM, C. G., Steven, T. A., Rowley, P. D., Glassgold, L. B., and Anderson, J. J., 1983, Geologic map of the Tushar Mountains and adjoining areas, Marysvale volcanic field, Utah: U.S. Geological Survey Miscellaneous Investigations Series Map I-1430A, scale 1:50,000.

DARLING, Riki, and Chapman, D. S., 1979, Heat flow in western Utah (abs.): Geological Society of America Abstracts with Programs, v. 11, no. 6, p. 269.

DARTON, N. H., 1920, Geothermal data of the United States, including many original determinations of underground temperature: U.S. Geological Survey Bulletin $701,97 \mathrm{p}$.

DAVIS, A. E., Enderlin, D. E., Blahnik, D. E., Jacobson, J. J. and Weakley, S. A., 1980, Assessment of geothermal energy as a power source for U.S. aluminium reduction plants: Geothermal Resources Council, Transactions, v. 4, p. 495-498.

DAVIS, D. A., and Cook, K. L., 1983, Evaluation of lowtemperature geothermal potential in Utah and Goshen Valleys and adjacent areas, Utah, Part 1. Gravity survey: Utah Geological and Mineral Survey Report of Investigation, no. $179,138 \mathrm{p}$. 
Location and purpose of survey; topography and physiography of study area; general geology of area; structural features; summary of characteristics of thermal springs in area; gravity data from four surveys and 1099 stations; errors associated with gravity data compilation; density measurements and sample collections; drill hole information from 12 water wells, one wildcat oil and gas well, and one deep ore drill hole; complete Bouguer gravity anomaly map with two-mgal contour interval; gravity characteristics of fault zones and local horsts; gravity profiles and interpretive geologic cross sections; interrelationship of fault blocks as interpreted from the gravity data; geothermal significance of gravity survey; summary and conclusions; appendices showing principal facts of gravity stations, density measurements of rocks, and well logs.

DAVIS, M. C., 1984, Evaluation of low-temperature geothermal potential in north-central Box Elder County, Utah: Utah Geological and Mineral Survey Open-File Report, no. 47, 117 p.

See Davis and Kolesar (1985).

DAVIS, M. C., and Kolesar, P. T., 1985, Evaluation of lowtemperature geothermal potential in north-central Box Elder County, Utah: Utah Geological and Mineral Survey Report of Investigation, no. 192, 92 p.

Geography of study area; previous studies of the area; geology, structure, and Tertiary volcanic history; geophysical characteristics; complete Bouguer gravity and fault maps; surface water drainage patterns; ground water sources, aquifers, and flow systems; field sampling procedures; chemical analyses of water from wells and springs; total dissolved solid concentrations; trace element concentrations; temperature surveys; table showing chemical geothermometer and surface temperatures for water; discussion and table showing geothermal gradients; proposed geothermal model for area; other targets of possible geothermal interest; map showing ground water temperatures and total dissolved solids.

DE CICCO, D. A., Pera, E. M., Allen, E. G., and Lutz, G. A., 1977, Leasable mineral and waterpower land classification map of the Moab quadrangle, Utah, Colorado: U.S. Geological Survey Open-File Report 77-612, scale $1: 250,000$.

DENTON, E. H., 1976, Helium sniffer test, Newcastle, Utah 10-26 March 1976: U.S. Geological Survey OpenFile Report 76-421, 4 p.

Approximately 200 soil-gas samples collected two feet below the surface near a hot water irrigation well; interpretation of helium concentration data; location of area surveyed and points sampled; contour map of helium concentrations in air.

DENTON, E. H., 1977, Helium sniffer field test: Roosevelt Hot Springs, Utah, October 1975 and March 1976: U.S. Geological Survey Open-File Report 77-606, 6 p.
Examines data obtained with the helium sniffer from two brief visits to Roosevelt Hot Springs; profiles of helium concentrations in subsurface air measured on three different days along the same survey line; helium abundance in subsurface soil along a survey line.

DEPARTMENT OF GEOLOGY AND GEOPHYSICS, University of Utah, 1979, Final report: geothermal exploration in Utah: Department of Geology and Geophysics, University of Utah, Salt Lake City, Utah, Report, no. DOE/ID/01601, 67 p.

DE VRIES, J. L., 1982, Geothermal assessment of Cache Valley, Utah (abs.): Geological Society of America Abstracts with Program, v. 14, no. 6, p. 309.

See de Vries (1983).

DE VRIES, J. L., 1983, Evaluation of low-temperature geothermal potential of Cache Valley, Utah (abs.): American Association of Petroleum Geologists Bulletin, v. 67 , no. 8 , p. 1334 ; also, 1982 , Utah Geological and Mineral Survey Report of Investigation, no. 174, $112 \mathrm{p}$.

Statement of problem and objectives accomplished during the study; location of Cache Valley; previous hydrologic and geothermal studies in the area; regional and local stratigraphy, structure, and historical geology; description of two principal aquifers; recharge of principal groundwater reservoirs; description of seven groundwater districts in Cache Valley; field sampling procedures for analyses of water $\mathrm{pH}$, alkalinity, temperature, conductivity, and $\mathrm{Eh}$; procedures for measuring thermal gradients; laboratory analyses and procedures; results of measured temperatures; graphs showing measured temperature profiles of wells located in Cache Valley; table showing thermal gradient data; table showing general water chemistry data; use of chemical geothermometers to assist in geothermal exploration; surface temperatures, thermal gradients, chemical analyses, and geothermometry of North Logan, Benson, and Trenton warm water areas; conclusions of low-temperature geothermal potential in Cache Valley; suggestions for further investigations.

DICKSON, F. W., and Tunell, G., 1968, Mercury and antimony deposits associated with active hot springs in the western United States, in Ridge, J. D., ed., Ore deposits of the United States, 1933-1967: New York, American Institute of Mining and Metallurgic Engineers, v. 2, p. 1673-1701.

DIMENT, W. H., Urban, T. C., Sass, J. H., Marshall, B. V., Munroe, R. J., and Lachenbruch, A. H., 1975, Temperatures and heat contents based on conductive transport of heat, in White, D. E., and Williams, D. L., eds., Assessment of geothermal resources of the United States-1975: U.S. Geological Survey Circular 726, p. 84-103.

Describes heat flow provinces of the western United States; thermal model for temperature calculations at depth; range of temperatures expected for provinces; 
tables (in depth intervals up to ten kilometers) of heat stored beneath provinces; Utah values for the Basin and Range, Central Rocky Mountains, and Colorado Plateau Provinces; observed heat flow measurements in the continental United States.

DIPIPPO, Ronald, 1978, Geothermal power plants of the United States; a technical survey of existing and planned installations: National Technical Information Service Report, no. COO-4051-20, 129 p.

DIPIPPO, Ronald, 1984, Worldwide geothermal power development, 1984 overview and update: Geothermal Resources Council Bulletin, v. 13, no. 9, p. 3-12.

Table showing numbers of worldwide geothermal power plants per country; worldwide geothermal power plant capacity growth rates from 1978 to 1984 , and from 1984 to 1990; operational power plants in the United States; Utah's Milford (rated at $20 \mathrm{MWe}$ ) and Cove Fort power generation plans; discussion of operations of other programs throughout the world.

DIPIPPO, Ronald, 1985, Geothermal electric power, the state of the world - 1985: Geothermal Resources Council Bulletin, v. 14, no. 9, p. 3-7.

Summaries of available thermal information from several countries around the world; breakdown of geothermal activity by state; development of two southern Utah geothermal resources; development and power generation plans for Cove Fort-Sulphurdale and Roosevelt Hot Springs projects.

DOELLING, H. H., Campbell, J. A., Gwynn, J. W., and Perry J. I., 1980, Geology and mineral resources of Box Elder County, Utah: Utah Geological and Mineral Survey Bulletin, no. 115, 251 p.

DOUZE, E. J., and Laster, S. J., 1979, Seismic array noise studies at Roosevelt Hot Springs, Utah, geothermal area: Geophysics, v. 44, no. 9, p. 1570-1583.

Location and general geology of the Roosevelt Hot Springs area; objective of study; effectiveness of geothermal ground-noise method in reservoir exploration; three of six seismometer arrays discussed; location of six seismometer arrays; computation of power spectra, spectral estimates, and $\mathrm{f}-\mathrm{k}$ spectra; graph showing measured velocity versus frequency derived from $\mathrm{f}-\mathrm{k}$ spectra from a noisy period; graph showing theoretical and experimental coherences of signals from two seismometers separated by 54 meters; illustrations showing experimental and theoretical frequency-wavelength ( $\mathrm{f}-\mathrm{k}$ ) spectrum at different conditions; procedures for estimating noise velocities; conclusions of study.

DUFFIELD, W. A., and Guffanti, M., 1981, The geothermal research program of the U.S. Geological Survey: U.S. Geological Survey Open-File Report 81-564, 108 p.; also, 1982, U.S. Geological Survey Circular 862, 15 p.

DURHAM, Jon, 1977, Environmental analysis, prepared for six $3,000+/-m(10,000+/-f t)$ deep, geothermal exploratory test wells in the Roosevelt Hot Springs unit,
Beaver County, Utah: U.S. Geological Survey Conservation Division Environmental Assessment Report, no. 59, p. 7-9, 13.

DURHAM, Jon, and Hoops, R., 1977, Environmental analysis prepared for geothermal lease U-32256, Republic Geothermal, Incorporated; Thermo Hot Springs KGRA, Utah: U.S. Geological Survey Conservation Division, Office of the Area Geothermal Supervisor, Environmental Assessment, no. 83, $50 \mathrm{p}$.

EARTH SCIENCE LABORATORY/University of Utah Research Institute, 1979, Quarterly, yearly, and cumulative epicenter maps for earthquakes: $38.250-38.750 \mathrm{de}-$ grees north latitude, 112.250 - 113.000 degrees west longitude (Roosevelt to Cove Fort-Sulphurdale area); 239 earthquakes for January 1, 1977 - December 31, 1978; hypocenter parameter listing: Earth Science Laboratory/University of Utah Research Institute Open-File Report, no. UT/RHS/ESL-1, unpaginated.

EARTH SCIENCE LABORATORY/University of Utah Research Institute, 1980, Reference list: Monroe Hot Springs area and vicinity, Sevier County, Utah: Earth Science Laboratory/University of Utah Research Institute Open-File Report, no. UT/MHS/ESL-1, 4 p.

EAST, J., 1981, Hot dry rock geothermal potential of Roosevelt Hot Springs area: review of data and recommendations: National Technical Information Service Report, no. LA-8751-HDR, 46 p.

Hot dry rock potential of the Roosevelt area; local geology and structure; stratigraphy; hot spring deposits; gravity, magnetic, and seismic data; thermal measurements; drilling history; hydrothermal alteration assemblages; water chemistry; hydrothermal reservoir configuration; target for hot dry rock reservoir rock; east-west geologic cross section; temperature-depth profile; interpretive two-dimensional model for gravity profile.

EATON, G. P., 1979, A plate tectonic model for late Cenozoic crustal spreading in the western United States, in Riecker, R. E., ed., Rio Grande Rift: Tectonics and Magmatism: American Geophysical Union, Washington, D. C., p. 7-32.

EDMISTON, R. C., 1979, Ore deposits as exploration models for geothermal reservoirs in carbonate rocks in the eastern Great Basin: Geothermal Resources Council, Transactions, v. 3, p. 181-184.

EDMISTON, R. C., 1982, A review and analysis of geothermal exploratory drilling results in the northern Basin and Range geologic province of the USA from 1974 through 1981: Geothermal Resources Council, Transactions, v. 6, p. 11-14.

EDMISTON, R. C., and Benoit, W. R., 1985, Characteristics of Basin and Range geothermal systems with fluid temperatures of $150^{\circ}$ to $200^{\circ} \mathrm{C}$ : Geothermal Resources Council Bulletin, v. 14 , no. 4 , p. 3-10. 
Discovery of six Basin and Range geothermal reservoirs with fluid temperatures above $200^{\circ} \mathrm{C}$ and ten systems with temperatures of $150^{\circ}$ to $200^{\circ} \mathrm{C}$; table showing measured temperatures and geochemical base temperatures of moderate- and high-temperature geothermal systems in the northern Basin and Range; location of the Cove Fort geothermal reservoir; general geology of Cove Fort area and extent of thermal anomaly; brief exploration history of Cove Fort area and temperature ranges encountered; statistics from other Basin and Range geothermal areas including Thermo, Utah; significance of maximum fluid entry temperature measurements, temperature reversals, and temperatures at depth; problems involved in determining the point an unsuccessful exploratory well has sufficiently tested a prospect; graph depicting mean temperatures and standard deviations for 23 wells from several areas including Roosevelt; Basin and Range thermal water variations; graphs showing silica and $\mathrm{Na}-\mathrm{K}-\mathrm{Ca}$ base temperatures vs. maximum field temperatures; conclusions.

EMBREE, G. F., 1970, Lateral and vertical variations in a Quaternary basalt flow-petrography and chemistry of the Gunlock flow, southwestern Utah: Brigham Young University Geology Studies, v. 17, pt. 1, p. 67-115.

ENERGY SERVICES, INCORPORATED (Idaho Falls), 1982, Floral-greenhouse geothermal-heating demonstration: final report, January 24, 1979 - September 30, 1982: National Technical Information Service Report, no. DOE/ET/27056-5, $132 \mathrm{p}$.

ENGLAND, A. W., and Johnson, G. R., 1976, Thermal microwave detection of near-surface thermal anomalies: United Nations symposium on the development and use of geothermal resources, 2d, San Francisco, California, 1975, Proceedings, v. 2, p. 971-977.

ERICKSON, M. P., 1973, Volcanic rocks of the Milford area, Beaver County, Utah, in Geology of the Milford area: Utah Geological Association Publication 3, p. 13-22.

ERICKSON, M. P., and Dasch, E. J., 1963, Geology and hydrothermal alteration in northwestern Black Mountains and southern Shauntie Hills, Beaver and Iron Counties, Utah: Utah Geological and Mineral Survey Special Studies 6; also, 1964, Geoscience Abstracts, v. 6 , no. 8, p. 15-16 (6-3238).

EVANS, S. H., Jr., compiler, 1977, Geologic map of the central and northern Mineral Mountains, Utah: University of Utah, Department of Geology and Geophysics Report, no. 77-7, scale 1:24,000.

EVANS, S. H., Jr., 1978, Studies in Basin and Range volcanism: Salt Lake City, Utah, University of Utah, unpublished Ph.D. thesis, 119 p.

EVANS, S. H., Jr., 1979, Utah geothermal update: Third Annual Stanford Geothermal Conference and Workshop, Proceedings, p. 4.42-4.43.
EVANS, S. H., Jr., 1980, Summary of potassium/argon age dating - 1979: University of Utah, Department of Geology and Geophysics Report, no. DOE/ET/28392-41, 30 p.

EVANS, S. H., Jr., 1982, Summary of potassium/argon dating - 1982: Earth Science Laboratory/University of Utah Research Institute Report, no. DOE/ID/12079-82, 8 p.

EVANS, S. H., Jr., and Brown, F. H., 1980, Summary of potassium/argon age dating - 1980: Earth Science Laboratory/University of Utah Research Institute Report, no. DOE/ID/12079-23, 27 p.

EVANS, S. H., Jr., and Brown, F. H., 1981, Summary of potassium/argon dating - 1981: Earth Science Laboratory/University of Utah Research Institute Report, no. DOE/ID/12079-45, 29 p.

EVANS, S. H., Jr., Crecraft, H. R., and Nash, W. P., 1980, $\mathrm{K} / \mathrm{Ar}$ dates of silicic volcanics in Twin Peaks/Cove Creek Dome area, southwestern Utah: Isochron/West, no. 28, p. 21-24.

EVANS, S. H., Jr., and Nash, W. P., 1975, Low-temperaure rhyolite from the Roosevelt geothermal area, Utah (abs.): Geological Society of America Abstracts with Programs, v. 7, no. 7, p. 1070.

Description of a suite of Quaternary silicic volcanic rocks associated with Roosevelt Hot Springs geothermal area; chemical analyses and mineralogy of six local obsidians; quench temperatures obtained from $\mathrm{Fe}$-Ti oxide and Kudo-Weill plagioclase geothermometers; calculated water fugacities; calculated depths of magma source region; regional paleogeothermal gradient; speculation on origin of lavas.

EVANS, S. H., Jr., and Nash, W. P., 1978, Quaternary rhyolite from the Mineral Mountains, Utah, U.S.A.: University of Utah, Department of Geology and Geophysics Final Report, v. 77-10, 59 p.

EVANS, S. H., Jr., and Nielson, D. L., 1982, Thermal and tectonic history of the Mineral Mountains intrusive complex: Geothermal Resources Council, Transactions, v. 6, p. 15-18.

EVANS, S. H., Jr., and Steven, T. A., 1982, Rhyolites in the Gillies Hill-Woodtick Hill area, Beaver County, Utah: Geological Society of America Bulletin, v. 93, no. 11, p. 1131-1141.

FELMLEE, J. K., and Cadigan, R. A., 1978, Determination of uranium in source rocks by using radium in Crystal Springs, Great Salt Lake area, Utah: U.S. Geological Survey Open-File Report 78-102, 35 p.; also, 1977, U.S. Geological Survey Circular 753, p. 48-50.

FELTIS, R. D., and Goode, H. D., 1961, Production and use of fresh water from the Ashley Valley oil field, Uintah County, Utah, in Geological Survey research 1961: U.S. Geological Survey Professional Paper 424-C, p. C90-C93. 
FETH, J. H., and Barnes, I., 1979, Spring-deposited travertine in eleven western States: U.S. Geological Survey Water-Resources Investigations Report 79-35, 1 plate with text.

FIORE, J. N., 1980, Overview and status of the U.S. Department of Energy's industry-coupled geothermal reservoir assessment program: Geothermal Resources Council, Transactions, v. 4, p. 201-204.

FISHMAN, H. S., 1976, Geologic structure and regional gravity of a portion of the High Plateaus of Utah: Salt Lake City, Utah, University of Utah, unpublished Masters thesis, $134 \mathrm{p}$.

FITCH, W. E., 1927, Mineral waters of the United States and American spas: Philadelphia and New York, Lea and Febiger, $799 \mathrm{p}$.

FLANIGAN, V. J., and Campbell, D. L., 1981, Geophysical measurements in the Beaver Basin, west-central Utah: Part I - Slingram, magnetic and self-potential profiles: U.S. Geological Survey Open-File Report 81-199, 18 p.

FLECK, R. J., Anderson, J. J., and Rowley, P. D., 1975, Chronology of mid-Tertiary volcanism in High Plateaus region of Utah, in Cenozoic geology of southwestern High Plateaus of Utah: Geological Society of America Special Paper 160, p. 53-61.

FOLEY, Duncan, 1982, Hydrothermal systems of central Utah; a regional perspective (abs.), in Program and abstracts for the Utah Geological Association, 1982 symposium on the overthrust belt of Utah: Utah Geological Association Publication 11, p. 18.

FOLEY, Duncan, 1984, U.S. Department of Energy state coupled resource assessment program - final report for FY 1983: Earth Science Laboratory University of Utah Research Institute Report, no. DOE/ID/12079-115, $26 \mathrm{p}$.

FOLEY, Duncan, Brophy, G. P., Mink, L. L., and Blackett, R. E., 1980, The state coupled program - a new emphasis: Geothermal Resources Council, Transactions, v. 4, p. $779-782$.

FOLEY, Duncan, and Dorscher, M., 1982, Tables of colocated geothermal sites and BLM wilderness study areas: Earth Science Laboratory/University of Utah $\mathrm{Re}$ search Institute Report, no. DOE/ID/12079-88, 168 p.

FOLEY, Duncan, Wright, P. M., Struhsacker, D. W., Nichols, C. R., Mink, L. L., Brophy, G. P., Grim, P. J., and Berry, G., 1979, State coupled resource assessment program - an update: Geothermal Resources Council, Transactions, v. 3, p. 217-220.

FORNES, A. O, 1981, Direct-use geothermal district heating projects in the U.S. - a summary: Geo-heat Center Quarterly Bulletin, v. 6, no. 3, p. 3-6.

FORREST, R. J., 1980, Historical synopsis of the Roosevelt Hot Springs geothermal field, Utah, in Nielson, D. L., ed., Geothermal systems in central Utah: Geothermal
Resources Council Annual Meeting, Salt Lake City, Utah, Guidebook to Field Trip, no. 7, p. 18-24.

Outlines discovery and development of Roosevelt Hot Springs by various companies, organizations, and institutions; chronological listing of developments by Phillips Petroleum Company and by other parties; map of land status at Roosevelt Hot Springs.

FRANGOS, W. A., and Ward, S. H., 1980, Bipole-dipole survey at Roosevelt Hot Springs KGRA, Beaver County, Utah: Earth Science Laboratory/University of Utah Research Institute Report, no. DOE/ID/12079-15, $41 \mathrm{p}$.

Bipole-dipole survey to evaluate technique for geothermal prospecting; general geophysics of study area; survey procedures and results; maps of topographic base with transmitter locations and apparent resistivities of individual transmitters.

FUCHS, R. L., and Huttrer, G. W., 1975, Geothermal energy; slow-growing industry finally heats up: Engineering and Mining Journal, v. 176, no. 1, p. 89-93.

GABBERT, S. C., 1980, Gravity survey of parts of Millard, Beaver, and Iron Counties, Utah: Salt Lake City, Utah, University of Utah, unpublished Masters thesis, $107 \mathrm{p}$.

GALYARDT, G. L., and Rush, F. E., 1981, Geologic map of the Crater Springs known geothermal resources area and vicinity, Juab and Millard Counties, Utah: U.S. Geological Survey Miscellaneous Investigations Series Map I-1297, scale 1:24,000.

Lithology, structure, topography, road and jeep trails, and county line in KGRA; map legend describes alluvial and eolian deposits, hydrothermal related deposits, Lake Bonneville deposits, pre-lake deposits, volcanic and pre-volcanic rocks; index map shows quadrangle names and boundaries in the area of the geologic map.

GARDNER, Susan, Williams, J. M., and Brougham, G. W., 1976, Audio-magnetotelluric data log and station location map for Monroe-Joseph KGRA, Utah: U.S. Geological Survey Open-File Report 76-411, 4 p.

GARDNER, Susan, Williams, J. M., and Hoover, D. B., 1976, Audio-magnetotelluric data $\log$ and station location map for Lund known geothermal resource area, Utah: U.S. Geological Survey Open-File Report 76-410, $4 \mathrm{p}$.

GARDNER, Susan, Williams, J. M., and Long, C. L., 1976, Audio-magnetotelluric data log, and station location map for Thermo known geothermal resource area, Utah: U.S. Geological Survey Open-File Report 76-412, $5 \mathrm{p}$.

GEONOMICS, INCORPORATED, 1976a, A comparison of hydrothermal reservoirs of the western United States: Electric Power Research Institute Topical Report 3, EPRI ER-364, $170 \mathrm{p}$. 
GEONOMICS, INCORPORATED, 1976b, Getty Oil Company surface geophysical surveys, Roosevelt Hot Springs: Earth Science Laboratory/University of Utah Research Institute Open-File Report, no. UT/RHS/GOC-1.1, unpaginated.

Fifteen miles of electrical resistivity survey profiles with report; two contoured maps with University of Utah data; maps of dipole-dipole electrical resistivity survey; interpretations and geology.

GEOTHERMAL POWER CORPORATION, 1978a, Roosevelt Hot Springs thermal gradient data for hole number 15 , temperature, water analysis, and wire line survey: Earth Science Laboratory/University of Utah Research Institute Open-File Report, no. UT/RHS/GPC-3, unpaginated.

Daily drilling reports and drilling time log for Geothermal Power Corporation well 15; brief formation description; drilling times and depths; chart and graph of well depths and corresponding temperatures; Sun Well Logging, Incorporated, lithologic log for well 15.

GEOTHERMAL POWER CORPORATION, 1978b, Shallow thermal gradient hole data for 14 holes near Roosevelt Hot Springs, Utah: Earth Science Laboratory/University of Utah Research Institute Open-File Report, no. UT/RHS/GPC-1, unpaginated.

Temperature, lithology, and heat flow calculations; lithologic logs; temperature-depth logs; maps of topography and lease position of Geothermal Power Corporation.

GEOTHERMAL POWER CORPORATION, 1982, Geothermal reservoir assessment, Roosevelt Hot Springs: final report, October 1, 1977 - June 30, 1982: National Technical Information Service Report, no. DOE/ET/28406-1, $81 \mathrm{p}$.

Regional geologic setting and history; stratigraphy; gravity, aeromagnetics, geoelectrical, and heat flow survey interpretations; hydrologic regime and ground water chemistry; source of geothermal heat and reservoir configuration; exploration history and strategies; gravity profile with interpretive geological cross section.

GEOTHERMAL RESOURCES COUNCIL BULLETIN, 1980a, Utah reinjection agreement signed: Geothermal Resources Council Bulletin, v. 9, no. 7, p. 10.

Memorandum of agreement signed that provides for review of proposals to inject geothermal and heatpumping water into natural channels; regulatory agencies named.

GEOTHERMAL RESOURCES COUNCIL BULLETIN, $1980 \mathrm{~b}$, Utah state lease sale results: Geothermal Resources Council Bulletin, v. 9, no. 9, p. 12.

Bid received for one of 12 geothermal steam housing tracts; amount paid and location of tract; temperature ranges of existing springs in area.

GEOTHERMAL RESOURCES COUNCIL BULLETIN, 1980c, Utah geothermal greenhouses produce large tomato crop: Geothermal Resources Council Bulletin, v. 9, no. 10, p. 17.

Two ton tomato crop from a geothermal Utah farm; layout of greenhouses and tomato plant arrangements; temperatures of wells and total dissolved solids content of thermal waters; cost savings; location of area; future geothermal power development plans.

GEOTHERMAL RESOURCES COUNCIL BULLETIN, 1980d, Wells completed at Utah prison site: Geothermal Resources Council Bulletin, v. 9, no. 11, p. 15.

State of Utah completed two exploratory wells for a space-heating project at Crystal Hot Springs; project funding and purpose; depth and temperatures of first well.

GEOTHERMAL RESOURCES COUNCIL BULLETIN, 1981a, Utah Legislature to consider geothermal bill: Geothermal Resources Council Bulletin, v. 10, no. 1, p. 16.

Geothermal Conservation Act of 1981 established to assign regulatory authority of geothermal energy to the Division of Water Rights; other conditions stated in the act.

GEOTHERMAL RESOURCES COUNCIL BULLETIN, 1981b, Roosevelt Hot Springs geothermal pact gets approval: Geothermal Resources Council Bulletin, v. 10, no. 1, p. 16.

Utah Public Service Commission approved a contract between Phillips Petroleum Company and Utah Power and Light Company for producing electricity with geothermal steam; Phillips to supply the steam for Utah Power and Light $20 \mathrm{MWe}$ plant.

GEOTHERMAL RESOURCES COUNCIL BULLETIN, 1981c, State may receive MX study money for geothermal: Geothermal Resources Council Bulletin, v. 10, no. 2, p. 13.

Application for funds to study the feasibility of using geothermal energy for powering the MX system; feasibility study to be completed March 1981; consideration of other energy sources.

GEOTHERMAL RESOURCES COUNCIL BULLETIN, 1981d, Utah Roses holds geothermal operation open house: Geothermal Resources Council Bulletin, v. 10, no. 2 , p. 13 .

Open house held for Utah Roses, Inc. geothermal greenhouses; water temperatures and well depth; estimated cost of heating operation; long range construction plans; permitting delay for the discharge of geothermal production fluid into the Jordan River.

GEOTHERMAL RESOURCES COUNCIL BULLETIN, 1981e, Utah geothermal bill passes: Geothermal Resources Council Bulletin, v. 10, no. 2, p. 13.

Utah Senate and House passed a bill establishing guidelines for development of Utah's geothermal energy; Division of Water Rights named as the regulatory agency. 
GEOTHERMAL RESOURCES COUNCIL BULLETIN, 1981f, Utah Prison exploration well completed: Geothermal Resources Council Bulletin, v. 10, no. 2, p. 13.

Completion of a 1005 foot exploratory well; location and water temperatures of well; source of funds for the geothermal space-heating prison project.

GEOTHERMAL RESOURCES COUNCIL BULLETIN, $1981 \mathrm{~g}$, Geothermists participate in CATMECS meeting: Geothermal Resources Council Bulletin, v. 10, no. 3, p. 13.

Forty attendees to the tenth meeting of the Centers for the Analysis of Thermal-Mechanical Energy Conversion Concepts; topics addressed; availability of meeting report.

GEOTHERMAL RESOURCES COUNCIL BULLETIN, 1981h, Utah PUC gives approval to power plant: Geothermal Resources Council Bulletin, v. 10, no. 3, p. 13-14.

Utah Public Service Commission approves a contract between Phillips Petroleum Company and Utah Power and Light for use of geothermal steam to produce electricity.

GEOTHERMAL RESOURCES COUNCIL BULLETIN, 1981i, Environmental assessment released on first Utah geothermal power plant: Geothermal Resources Council Bulletin, v. 10, no. 8, p. 8.

Release of the draft environmental assessment on the proposed $20 \mathrm{MWe}$ geothermal power plant at Roosevelt Hot Springs; construction schedule; environmentai concerns; six commercial wells drilled at Roosevelt.

GEOTHERMAL RESOURCES COUNCIL BULLETIN, 1981j, Utah geothermal unit approved: Geothermal Resources Council Bulletin, v. 10, no. 9, p. 21.

Utah Division of State Lands approval of the formation of the Drum Mountains Geothermal Unit; location and size of the unit; unit agreement provisions.

GEOTHERMAL RESOURCES COUNCIL BULLETIN, 1981k, Biphase unit installed at Roosevelt Hot Springs: Geothermal Resources Council Bulletin, v. 10, no. 11, p. 13-14.

Equipment for Biphase Energy Systems mobile generating plant prepared for operation at Roosevelt Hot Springs in September of 1981; expected production; Utah Power and Light plans to study economic and technical feasibility of a $7 \mathrm{MWe}$ and a $20 \mathrm{MWe}$ steam turbine system; endurance test scheduled for spring 1982 depending on success of tests.

GEOTHERMAL RESOURCES COUNCIL BULLETIN, 1982a, Roosevelt Hot Springs produces power, Utah Power and Light customers get their first geothermally produced electricity: Geothermal Resources Council Bulletin, v. 11, no. 1, p. 3-4.

Date first geothermal generating unit at Roosevelt $\mathrm{Hot}$ Springs began supplying electricity to Utah Power and Light; cooperative project of Utah Power and Light,
Phillips Petroleum Company, Biphase Energy Systems, and Electrical Power Research Institute.

GEOTHERMAL RESOURCES COUNCIL BULLETIN, 1982b, WESTEC gets start-up contract: Geothermal Resources Council Bulletin, v. 11, no. 2, p. 23.

WESTEC Services, Inc. to provide start-up services for Utah Power and Light Company's Rotary Separator Turbine geothermal project at Roosevelt Hot Springs; total cost of contract and duration of project.

GEOTHERMAL RESOURCES COUNCIL BULLETIN, 1982c, Utah lease sale gets no bids; Geothermal Resources Council Bulletin, v. 11, no. 2, p. 23.

No bids submitted for geothermal lease sale units in Box Elder and Millard counties, Utah.

GEOTHERMAL RESOURCES COUNCIL BULLETIN, 1982d, Phillips plans Utah exploration: Geothermal Resources Council Bulletin, v. 11, no. 4, p. 22.

Phillips Petroleum Company plans exploratory geothermal drilling in the Drum Mountains unit of Utah; location of area; previously reported geothermal gradients.

GEOTHERMAL RESOURCES COUNCIL BULLETIN, 1982e, Crystal Hot Springs water rights studied: Geothermal Resources Council Bulletin, v. 11, no. 5, p. 16.

Hearing held in 1982 to investigate the administration of water rights in Crystal Hot Springs area; successful drilling and test results in the area.

GEOTHERMAL RESOURCES COUNCIL BULLETIN, 1982f, Phillips to drill new Roosevelt Hot Springs well: Geothermal Resources Council Bulletin, v. 11, no. 5, p. 17.

Plans for Phillips to drill more wells for the $20 \mathrm{MWe}$ geothermal power plant; well locations and projected depths.

GEOTHERMAL RESOURCES COUNCIL BULLETIN, $1982 \mathrm{~g}$, Union is sole bidder for Utah geothermal leases: Geothermal Resources Council Bulletin, v. 11, no. 5, p. 17.

Total bonus paid by Union Oil Company of California for 1314.57 acres of land for geothermal leasing from the state of Utah; location of lands acquired.

GEOTHERMAL RESOURCES COUNCIL BULLETIN, 1982h, Hunt bid tops Utah lease sale: Geothermal Resources Council Bulletin, v. 11, no. 7, p. 19.

Location of tract and amount of W. H. Hunt's bid for leasing unit 4 in the Cove Fort-Sulphurdale KGRA; bids on four other tracts.

GEOTHERMAL RESOURCES COUNCIL BULLETIN, 1982i, Utah State Prison well to be tested: Geothermal Resources Council Bulletin, v. 11, no. 8, p. 14-15.

Plans for a 30 day pump test on a well at the Utah State Prison; recovery monitoring to last seven to ten days; management and interpretation plans for the tests. 
GEOTHERMAL RESOURCES COUNCIL BULLETIN, 1982j, Hunt Oil plans four Utah wells: Geothermal Resources Council Bulletin, v. 11, no. 8, p. 15.

Hunt Oil Company plans to drill up to four $7000 \mathrm{ft}$ deep geothermal wells in Iron County, Utah; availability of a copy of the plan of operation.

GEOTHERMAL RESOURCES COUNCIL BULLETIN, 1982k, Drilling confirms Roosevelt Hot Springs geothermal potential: Geothermal Resources Council Bulletin, v. 11 , no. 10 , p. 19.

Combined flow capacity of two Phillips Petroleum Company wells; list of participating resource companies at Roosevelt.

GEOTHERMAL RESOURCES COUNCIL BULLETIN, 1983a, Roosevelt Hot Springs power plant on target: Geothermal Resources Council Bulletin, v. 12, no. 1, p. 23.

Completion of two of four stages of a Utah Power and Light 20 MWe power plant at Roosevelt Hot Springs; schedule of completion of fourth stage; results of Phillips Petroleum's recent drilling projects; electrical power tests conducted at Roosevelt.

GEOTHERMAL RESOURCES COUNCIL BULLETIN, 1983b, Roosevelt Hot Spring activity update: Geothermal Resources Council Bulletin, v. 12, no. 2, p. 26.

Testing of a $1.6 \mathrm{MWe}$ Transamerica Delaval Biphase Rotary Separator Turbine at Roosevelt Hot Springs; total electrical production during the test; construction schedule of a $20 \mathrm{MWe}$ single-flash power plant.

GEOTHERMAL RESOURCES COUNCIL BULLETIN, 1983c, Geothermal to warm prisoners: Geothermal Resources Council Bulletin, v. 12, no. 10, p. 14-15.

Development and construction costs for converting the Utah State Prison minimum security building to a geothermal heating system; breakdown of DOE and State's costs; future plans.

GEOTHERMAL RESOURCES COUNCIL BULLETIN, 1984a, Biphase turbine to operate for UP\&L: Geothermal Resources Council Bulletin, 1984, v. 13, no. 6, p. 1.

A wellhead geothermal power unit to be installed at Roosevelt, Utah; expected power generation; unique features of unit; Utah Power and Light production history at Roosevelt.

GEOTHERMAL RESOURCES COUNCIL BULLETIN, 1984b, Dry steam discovery/blowout: Geothermal Resources Council Bulletin, v. 13, no. 1, p. 27-28.

Discovery of a dry steam well near Cove Fort, Utah; estimated flow of dry steam and well head temperature; new well drilled in area; new development and plans for sale of power.

GEOTHERMAL RESOURCES COUNCIL BULLETIN, 1984c, Dry steam discovery/blow out: Geothermal Resources Council Bulletin, v. 13, no. 2, p. 21-22.
Location and field operator for Olga's Well No. 34-7; initial drilling program for 34-7; time and date of blowout; estimated flow of "dry steam" from the blowout; efforts made to contain the well; equipment used; successful containment; power sale contract between the operator and Provo City; future development plans of the operator.

GEOTHERMAL RESOURCES COUNCIL BULLETIN, 1984d, Second well completed at Cove Fort: Geothermal Resources Council Bulletin, v. 13, no. 4, p. 26.

Completion of a dry steam well at Cove Fort, Utah; location and depth of well; plans for further drilling.

GEOTHERMAL RESOURCES COUNCIL BULLETIN, 1984e, Unidyne to acquire geothermal division of Amax: Geothermal Resources Council Bulletin, v. 13, no. 4, p. 27.

Preliminary agreement between Amax and Unidyne for Unidyne's purchase of Steam Reserve Corporation; terms of the agreement; properties involved in the agreement.

GEOTHERMAL RESOURCES COUNCIL BULLETIN, 1984f, Roosevelt Hot Springs plant goes on line: Geothermal Resources Council Bulletin, v. 13, no. 11, p. 24.

Utah Power and Light's $\$ 35$ million, $20 \mathrm{MWe}$ power plant start up; plant designers and construction company; further Utah Power and Light plans.

GEOTHERMAL RESOURCES COUNCIL BULLETIN, $1984 \mathrm{~g}$. Provo to purchase geothermal power: Geothermal Resources Council Bulletin, v. 13, no. 11, p. 24.

Plans underway for Provo City to purchase geothermal power from wells at Cove Fort, Utah; developer of the wells; estimated power output from the Cove Fort area; approximate cost for Provo citizens.

GEOTHERMAL RESOURCES COUNCIL BULLETIN, 1985a, UP\&L wins award for energy innovation: Geothermal Resources Council Bulletin, v. 14, no. 1, p. 21-22.

Utah Power and Light Company wins an award for research and development of a high-efficiency turbine generator for the Roosevelt Hot Springs area; characteristics of the power plant; cost comparisons and projected savings.

GEOTHERMAL RESOURCES COUNCIL BULLETIN, 1985b, UP\&L subsidary organized to explore energy resources: Geothermal Resources Council Bulletin, v. 14 , no. 1, p. 22.

Organization of Energy National, Inc.; purpose of new company; maximum equity financing for Energy National, Inc.

GEOTHERMAL RESOURCES COUNCIL BULLETIN, 1985c, First power plant dedicated at Cove Fort, Utah: Geothermal Resources Council Bulletin, v. 14, no. 10, p. 5-6. 
Date and location of dedication ceremonies; speakers at the ceremonies; capacity and design of power plant; terms of agreement for Provo City's purchase of power; geothermal exploration history of the Cove Fort and Sulphurdale areas; production drilling; lifetime expectations of the field.

GEOTHERMEX, INCORPORATED, 1977, Geothermal potential of the lands leased by Geothermal Power Corporation in the Mineral Mountains, Beaver and Millard Counties: Earth Science Laboratory/University of Utah Research Institute Open-File Report, no. UT/RHS/GPC-2, 43 p.

Stratigraphy and structure of study area; gravity and aeromagnetic data interpretation; interpretations based on geoelectrical, seismic, and heat flow surveys; hydrology of surface and ground waters; geothermal regime; exploration history; maps of geology, gravity, aeromagnetics, and temperature gradients.

GEOTRONICS, INCORPORATED, 1976, Magnetotelluric resistivity cross sections - Roosevelt Hot Springs: Geotronics Corporation, scale: 1:24,000.

Magnetotelluric resistivity cross section from Roosevelt Hot Springs; magnetotelluric survey fence diagram of subsurface resistivities; magnetotelluric survey resistivities at 2000 feet below sea level.

GERTSON, R. C., and Smith, R. B., 1979, Interpretation of a seismic refraction profile across the Roosevelt Hot Springs, Utah and vicinity: Earth Science Laboratory/University of Utah Research Institute Report, no. DOE/ET/28392, 109 p.

Seismic study defines fault locations and assesses the source of the thermal anomaly at Roosevelt Hot Springs; geology and geophysics of study area; seismic data computations; interpretations of $\mathbf{P}$-wave travel times and construction of velocity-depth models to fit observed data; computer analysis of seismic refraction data; interpretation of amplitude variations of seismic diffraction data; two-dimensional gravity modeling from refraction data.

GETTY OIL COMPANY, 1978a, Getty well 52-21, Roosevelt Hot Springs - water analysis: Earth Science Laboratory/University of Utah Research Institute Open-File Report, no. UT/RHS/GOC-3, unpaginated.

Water analyses for well 52-21 and Jefferson well; rework history; charts and water analyses taken from depth.

GETTY OIL COMPANY, 1978b, Getty well 52-21, Roosevelt Hot Springs - well report: Earth Science Laboratory/University of Utah Research Institute Open-File Report, no. UT/RHS/GOC-2, unpaginated.

Well history; bit record; lithologic log; temperature and pressure logs; subsurface temperature survey.

GILBERT, G. K., 1890, Lake Bonneville: U.S. Geological Survey Monograph, v. 1, p. 332-335.
Location and geomorphology of Fumarole Butte; temperature ranges of steam issuing from fissures; temperature ranges of a group of local hot springs; geologic history of area; persistence of volcanic heat in study area; other basalt localities of Lake Bonneville.

GLENN, W. E., Chapman, D. S., Foley, D., Capuano, R. M., Sibbett, B. S., Cole, D., and Ward, S. H., 1980, Geothermal exploration at Hill Air Force Base, Ogden, Utah: Earth Science Laboratory/University of Utah Research Institute Report, no. DOE/ET/28392-42, 89 p.; also, (abs.), Geological Society of America Abstracts with Programs, v. 12, no. 6, p. 274.

Identifies and tests favorable geologic structures for thermal fluids; survey of mercury concentration in soil profiles and soil traverses; fluid geochemical analyses of thermal waters, wells, and cold surface waters; application of geothermometers to water analysis; ground water model of fluid path from source regions to spring and well locations; gravity and reflection seismic surveys and interpretations; thermal gradient drilling and well $\log$ data interpretation; seismic sections and gravity profiles; plates showing well logs with natural gamma, resistivity, temperature gradient, temperature, and caliper readings.

GLENN, W. E, and Hulen, J. B., 1979a, A study of well logs from Roosevelt Hot Springs KGRA, Utah (abs.): Society of Petroleum Well Log Analysts, Transcripts, v. 2, paper no. ZZ, p. 1.

See Glenn and Hulen (1979b).

GLENN, W. E., and Hulen, J. B., 1979b, Interpretation of well $\log$ data from four drill holes at Roosevelt Hot Springs KGRA: Earth Science Laboratory/University of Utah Research Institute Report, no. DOE/ET/28392-27, 74 p.

Determination of geothermal reservoir characteristics based on well log data from four drill holes; lithologic, temperature, caliper, porosity, density, resistivity, natural gamma, and spontaneous potential logs for each drill hole; estimates of rock properties of alluvial material and igneous and metamorphic rocks based on geophysical logs; heat flow and fluid entries; plates of geologic log composites and coinciding geophysical logs.

GLENN, W. E., Hulen, J. B., and Nielson, D. L., 1980, A comprehensive study of LASL well C/T-2 (Phillips 9-1) Roosevelt Hot Springs KGRA, Utah, with applications to geothermal well logging: Los Alamos Scientific Laboratory Report LA-8686-MS, 175 p.

General geology and structure of area; petrographic study of drill hole cuttings to identify rock types and alteration phases of lithologic units; chemical analyses of composite samples from well $\mathrm{C} / \mathrm{T}-2$; analysis of oxygen and carbon isotopes to estimate temperature of deposition of hydrothermal minerals; measurement of bulk density, magnetic susceptibility, and thermal conductivity of cuttings; geophysical interpretation based on de- 
scription and data from temperature, caliper, acoustic, neutron, density, electrical conductivity, SP, and gamma ray logs; use of cross plots from log data to identify distinct lithologies and estimate porosity values; tables of petrographic summaries of cuttings, whole rock analyses versus well depth, neutron activation analyses, and oxygen isotope values versus well depth; plates of geophysical logs, and chemical, radiometric, and X-ray fluorescence data.

GLENN, W. E., and Ross, H. P., 1982, A study of well logs from Cove Fort-Sulphurdale KGRA, Millard and Beaver Counties, Utah: Earth Science Laboratory/University of Utah Research Institute Report, no. DOE/ID/12079-62, 39 p.

Description of well logs obtained from three wells in Cove Fort-Sulphurdale area; geological and geophysical setting; drill hole history and descriptions; well logs of lithology, mud, temperature, and several open-hole logs; log interpretations and stratigraphic correlation; plates of $\log$ composites for three wells, geologic map, various cross-plots, and directional survey results.

GLENN, W. E., Ross, H. P., and Atwood, J. W., 1982, Review of well logging in the Basin and Range known geothermal resource areas: Journal of Petroleum Technology, v. 34, no. 5, p. 1104-1118.

A U.S. Department of Energy Division of Geothermal Energy "industry coupled program" designed to accelerate development of high-temperature geothermal resources; comparison of geothermal investigation of well logging and well log analysis to those of the petroleum and mineral industries; applications of well logging to geothermal investigations; table showing types of well logs obtained in industry coupled drill holes from Cove Fort-Sulphurdale; types of well logs acquired for study; selected logs from geothermal gradient hole GPC-15, Roosevelt Hot Springs; general geology of the Roosevelt area; data from various logs taken at the area; graph showing correlation of well log data to volume percent mafic minerals in chip samples from a Roosevelt well; general geology of Cove Fort-Sulphurdale; Cove Fort-Sulphurdale well log data; data from other Basin and Range areas; conclusions.

GODWIN, L. H., Haigler, L. B., Rioux, R. L., White, D. E., Muffler, L. J. P., and Wayland, R. G., 1971, Classification of public land valuable for geothermal steam and associated geothermal resources: U.S. Geological Survey Circular 647, $18 \mathrm{p}$.

GOFF, F. E., and Decker, E. R., 1983, Candidate sites for future hot dry rock development in the United States: Journal of Volcanology and Geothermal Research, v. 15 , no. 1-3, p. 187-221.

GOFF, F. E., Laughlin, A., Aldrich, J., Ander, M., Arney, B., Decker, E., Gardner, J., Heiken, G., Kron, A., LaDelfe, C., Pettitt, R., and Shannon, S., 1981, Hot dry rock geothermal prospects, 1981: Geothermal Resources Council, Transactions, v. 5, p. 173-176.
GOFF, F. E., and Waters, A. C., 1980, Continental scientific drilling program thermal regimes: comparative site assessment geology of five magma-hydrothermal systems: Los Alamos National Laboratory Report, no. LA-8550-OBES, $100 \mathrm{p}$.

GOODE, H. D., 1978, Thermal waters of Utah: Utah Geological and Mineral Survey Report of Investigation 129, 183 p.; also, Department of Energy Report, no. DOE/ET/28393-7, $176 \mathrm{p}$.

Summary of occurrence of thermal waters in Utah; origin of thermal waters; hot springs along the Wasatch fault zone; uses for Utah thermal waters; collection of articles discussing areas with waters greater than or equal to 25 degrees $C$, areas with waters between 20 and 34.5 degrees $C$, and areas with waters between 15.5 and 19.5 degrees $C$; tables showing records of thermal springs and wells, and chemical analyses.

GOODE, H. D., 1979, Hot waters of western Utah: Rocky Mountain Association of Geologists Basin and Range Symposium, p. 371-380.

Origin of thermal waters in western Utah with temperatures greater than 35 degrees $\mathrm{C}$; possible domestic and industrial uses for thermal waters; descriptions of 21 areas with hot water occurrences including Crater, Roosevelt, Monroe-Red Hill-Joseph, Black Rock Desert, and Escalante Desert areas; table of selected chemical analyses of waters with temperatures greater than 35 degrees $C$.

GOODE, H. D., 1985, Hot water from the Ashley Valley oil field, in Picard, M. D. ed., Geology and energy resources, Uinta Basin of Utah: Utah Geological Association, Publication 12, p. 295-299.

GORNITZ, Vivien, 1979, Detection of hydrothermal alteration with 24-channel multispectral scanner data and quantitative analyses of linear features, Monroe geothermal area, Utah: International Symposium on Remote Sensing of Environment, 13th, Proceedings, v. 2, p. 825-834.

Purpose of report; general geologic setting of Monroe area; equipment used and procedures for thematic mapping; delineation of hydrothermally altered rocks on the digital classification map; recognition of lineaments and correlation of intense hydrothermal alteration with heavy fracturing; preparation of a fracture density map; procedures for checking statistical significance of data; linear features detected on Landsat imagery; map of Monroe test site alteration.

GRANT, S. K., and Best, M. G., 1979, Geologic map of the Lund quadrangle, Iron County, Utah: U.S. Geological Survey Open-File Report 79-1655, scale 1:24,000.

GREEN, R. T., 1981, Gravity survey of the southwestern part of the southern Utah geothermal belt: Salt Lake City, Utah, University of Utah, unpublished Masters thesis, $107 \mathrm{p}$.

See Green and Cook (1980a). 
GREEN, R. T., and Cook, K. L., 1980a, A gravity survey of the southwestern part of the southern Utah geothermal belt, Washington County, Utah: Earth Science Laboratory/University of Utah Research Institute Report, no. DOE/ID/12079-18, 116 p.

Purpose of survey; geology and structure of area; data acquisition, reduction, and compilation; interpretive geologic cross sections along gravity profiles; interpretation of regional and local gravity features; maps of Bouguer gravity and fourth order residual gravity; appendices of principal facts of gravity data, rock sample data, density measurements, and error analysis in modeling gravity profiles.

GREEN, R. T., and Cook, K. L., 1980b, Principal facts for gravity stations for the southwestern part of the southern Utah geothermal belt, Washington County, Utah: Earth Science Laboratory/University of Utah Research Institute Open-File Report, no. UT/UGB/GG-2, 22 p.

GREEN, Stanley, 1979, Developing geothermal legislation for Utah: Geothermal Resources Council, Transactions, v. 3, p. 279-282.

GREEN, Stanley, and Wagstaff, L. W., 1979, Utah geothermal commercialization planning: semi-annual progress report, January 1, 1979-June 30, 1979: Utah Division of Water Rights, 124 p.

GREIDER, B., 1976, Geothermal energy Cordilleran hingeline - west, in Hill, J. G., ed., Symposium on geology of the Cordilleran hingeline: Rocky Mountain Association of Geologists, Denver, p. 351-362.

GRIM, P. J., Nichols, C. R., Wright, P. M., Berry G. W., and Swanson, J., 1978, State maps of low-temperature geothermal resources: Geothermal Resources Council, Transactions, v. 2, sec. 1, p. 233-234.

Plan for a series of geothermal energy resource maps for 12 western states prepared by the National Geophysical and Solar-Terrestrial Data Center, including lowtemperature thermal resources; Utah map scale $1: 500,000$; source of data for maps; method of digitizing data; schedule for map production; applications for the nonspecialist; availability of maps.

GROSE, L. T., 1975, Geothermal energy; geology, exploration, and developments; Part 1., in Betz, F., Jr., ed., Environmental geology: Mineral Industries Bulletin, v. 14, no. 6 , p. 1-14.

GUFFANTI, Marianne, and Nathenson, M., 1980, Preliminary map of temperature gradients in the conterminous United States: Geothermal Resources Council, Transactions, v. 4, p. 53-56.

GUFFANTI, Marianne, and Nathenson, M., 1981, Temperature-depth data for selected deep drill holes in the United States obtained using maximum thermometers: U.S. Geological Survey Open-File Report 81-555, $100 \mathrm{p}$.
HAHL, D. C., and Mundorff, J. C., 1968, An appraisal of the quality of surface water in the Sevier Lake basin, Utah, 1964: State of Utah, Department of Natural Resources Technical Publication, no. 19,44 p.

HALLIDAY, M. E., 1978, Gravity and ground magnetic surveys in the Monroe and Joseph known geothermal areas and surrounding region, south-central Utah: Salt Lake City, Utah, University of Utah, unpublished Masters thesis, $164 \mathrm{p}$.

Map of survey area showing major geographic features and location of Monroe and Joseph; purpose of study; location of regional gravity survey; previous investigations; maps showing total ground magnetic intensity anomalies of the Red Hill Hot Springs and Joseph Hot Springs detailed grid; stratigraphy, Tertiary volcanic history, and structure of the study area; density and magnetic susceptibility measurements from rock samples; instrumentation used; regional and detailed gravity and ground magnetic data; gravity data reduction and terrain corrections; ground magnetic data reduction; error analysis; complete Bouguer gravity anomaly map of the survey area; polynomial surface filtering; methods of interpretation; interpretative geologic cross sections; gravity and magnetic profiles; summary and conclusions.

HALLIDAY, M. E., and Cook, K. L., 1978, Gravity and ground magnetic surveys in the Monroe and Joseph KGRA's and surrounding region, south-central Utah: University of Utah, Department of Geology and Geophysics Final Report, v. 77-7, 164 p.

See Halliday (1978).

HALLIDAY, M. E., Cook, K. L., and Sontag, R. J., 1978, Gravity and magnetic surveys as an aid to geothermal exploration in the Monroe-Marysvale area and vicinity, Utah (abs.): Geological Society of America Abstracts with Programs, v. 10, no. 5, p. 217.

Regional and detailed gravity and magnetic surveys used for geothermal exploration; relationship of faults, regional tectonics, and known geothermal systems; gravity used to determine fault locations and displacements; magnetic surveys used to locate faults and tufa mounds; 1,000 new gravity stations established in Sevier Valley, Sevier Plateau, Tushar Mountains, and Pavant Range; gravity patterns and anomaly.

HALLIN, J. S., 1973, Heat flow and radioactivity studies in Colorado and Utah: Laramie, Wyoming, University of Wyoming, unpublished Masters thesis, $107 \mathrm{p}$.

HAMBLIN, W. K., 1963, Late Cenozoic basalts of the St. George Basin, Utah, in Heylmun, E. B., ed., Geology of southwestern Utah: Intermountain Association of Petroleum Geologists Guidebook, 12th Annual Field Conference, p. 84-89.

HANNY, J. A., and Lunis, B. C., eds., 1979, Utah hydrothermal commercialization baseline: EG\&G-Idaho Operations Office, $86 \mathrm{p}$. 
HARRISON, R. F., 1980, Direct utilization of geothermal resources field experiments at Monroe, Utah: Terra Tek Report, no. TR 80-14, Preliminary Draft, 144 p.

Preliminary report on the development of a district heating system centered on Monroe-Red Hill KGRA to service the high school, city hall, fire station, and several stores in Monroe City; results from the completion of the first of three phases which include an environmental report, reservoir assessment, drilling and testing of a production well, and evaluation of the reservoir based on test results.

HARRISON, R. F., Blair, C. K., and Chapman, D. S., 1979, Development and testing of a small, moderatetemperature geothermal system, in Ramey, H. J., and Kruger, P., eds., Proceedings, fifth workshop, geothermal reservoir engineering: Stanford University, Interdisciplinary Research in Engineering and Earth Sciences, Geothermal Program Report, no. SGP-TR-40, p. 125-129.

Location and general geology of the Monroe-Red Hill geothermal system; structural controls; temperaturedepth profile patterns and heat loss; two cores drilled to define lithologies and structures; lithology and zones of artesian flow from a production test well; results of drawdown testing from a 70 hour pump test.

HARRISON, R. F., Blair, K., Sakashita, B., and Jones, A. H., 1980, Monroe City KGRA: Terra Tek Report, no. TR 80-30, 17 p.

Location of Monroe City, Utah; surface characteristics of the Monroe KGRA; dissolved solids concentration of the Monroe Springs discharge; structural control of the geothermal system; 21 line-km of $100 \mathrm{~m}$ dipole-dipole resistivity survey; resistivity trends; eight thermal gradient and test holes drilled and tested; graphs of temperature profiles in test holes; chemical analysis of waters; drilling problems, procedures, and temperature logs from a production test well; results of a 70 hour drawdown test; summary and conclusions.

HAUGH, G. R., 1978a, A preliminary geologic map of the Wildcat Creek area, eastern Beaver County, Utah: Utah Geology, v. 5, no. 1, p. 33-35.

HAUGH, G. R., 1978b, Late Cenozoic, cauldron-related silicic volcanism in the Twin Peaks area, Utah: Provo, Utah, Brigham Young University, unpublished Masters thesis, $53 \mathrm{p}$.

HAUSEL, W. D., and Nash, W. P., 1977, Petrology of Tertiary and Quaternary volcanic rocks, Washington County, southwestern Utah: Geological Society of America Bulletin, v. 88, no. 12, p. 1831-1842.

HEIKEN, Grant, Goff, F., and Cremer, G., 1982, Hot dry rock geothermal resource 1980: Los Alamos National Laboratory Report, no. LA-9295-HDR, 113 p.

HELTON ENGINEERING AND GEOLOGICAL SERVICES, INCORPORATED, 1978, Geothermal Power
Corporation well 15, section 18, township 27 south, range 9 west, Beaver County, Utah: Earth Science Laboratory/University of Utah Research Institute Open-File Report, no. UT/RHS/GPC-3, unpaginated.

Lithologic log; temperature survey; water samples and analyses; wireline sample; temperature gradient log.

HENDRICKSON, R. R., Green, S. J., Jones, A. H., and Winzenreid, R. W., 1978, Full-scale laboratory testing of experimental geothermal rock bits: Geothermal Resources Council, Transactions, v. 2, p. 267-270.

HEWITT, W. P., Stowe, C. H., and Stromberg, R. R., 1972, Utah's geothermal resources-location, potential, and administrative agencies, in Geothermal overviews of the western United States: Geothermal Resources Council Special Report 1, p. 149-160.

Location, general geology, and geothermal characteristics of Crater Springs and Roosevelt KGRAs; 31 additional geothermal resource provinces; map showing Utah thermal waters with temperatures and silica content; maps showing relationships of thermal waters to principal fault zones and Cenozoic igneous outcrops; Tintic mining district mine water temperatures and water table depths; Utah Power and Light customer and sales growth projections and increased construction costs; Utah energy sources, reserve estimates, and future outlook; agencies with regulatory authority; other significant geothermal articles.

HEYL, A. V., 1978, Unusual concentrations of elements in Monroe, Utah hot springs aprons: Utah Geological Association, Publication no. 7, p. 71 .

Results of elemental analyses of travertine mounds; model of circulation of thermal waters.

HEYLMUN, E. B., Jr., 1966, Geothermal power potential in Utah: Utah Geological and Mineral Survey Special Studies 14,28 p.

HINKLE, M. E., 1980, Survey of helium in soils and soil gases and mercury in soils at Roosevelt Hot Springs known geothermal resource area, Utah: U.S. Geological Survey Open-File Report 80-613, 34 p.

Survey examining relationships of helium and mercury to local geologic features; sample collection, preparation, and methods of analysis; survey results; table showing concentrations of helium and mercury in samples; maps of helium and mercury in soils; resistivity and thermal gradients.

HINKLE, M. E., 1981, Helium and mercury concentrations in the Roosevelt Hot Springs area, Utah (abs.), in Geological Survey Research 1981: U.S. Geological Survey Professional Paper 1275, p. 19.

Relationship of helium and mercury concentrations in soils, and helium in soil gases to the geothermal features of Roosevelt Hot Springs. 
HINKLE, M. E., Denton, E. H., and Bigelow, R. C., 1978, Helium in soil gases of the Roosevelt Hot Springs known geothermal resource area, Beaver County, Utah: U.S. Geological Survey Journal of Research, v. 6, no. 5, p. 563-569.

Objective of study; location and general geology of study area; procedures for collecting 180 soil samples; sample preparation and analysis; calculations and results; graph showing proportionality constant plotted against temperature; graph showing helium concentration in soil moisture and wet soil samples at Roosevelt; graph showing percent moisture in soil samples from Roosevelt; conclusions on helium migration patterns; helium concentrations at several drill hole locations; average helium concentrations for two traverses across Roosevelt.

HINKLE, M. E., and Harms, T. F., 1978, CS 2 and COS in soil gases of the Roosevelt Hot Springs known geothermal resource area, Beaver County, Utah: U.S. Geological Survey Journal of Research, v. 6, no. 5, p. 571-573.

Purpose of study; location and general geology of the Roosevelt Hot Springs; 144 soil gas samples collected along two traverses; sample collection procedures; methods and instrumentation for analyzing absorbed soil gases; results of study; migration patterns for compounds; conclusions.

HOGG, N. C., 1972a, High potassium calc-alkaline volcanic rocks from the eastern Great Basin (abs.): Geological Society of America Abstracts with Programs, v. 4, no. 6, p. 382 .

HOGG, N. C., 1972b, Shoshonitic lavas in west central Utah: Brigham Young University Geology Studies, v. 19 , pt. 2, p. 133-184.

HOLMES, R. D., 1979, Thermoluminescence dating of Quaternary basalts; continental basalts from the eastern margin of the Basin and Range Province, Utah and northern Arizona: Brigham Young University Geology Studies, v. 26, pt. 2, p. 51-64.

HOOVER, J. D., 1974, Periodic Quaternary volcanism in the Black Rock Desert, Utah: Brigham Young University Geology Studies, v. 21, pt. 1, p. 3-72.

HUERTAS, Fernando, 1979, In situ stress measurements in the Rocky and Star Ranges, Beaver County, Utah (abs.): Geological Society of America Abstracts with Programs, v. 11, no. 6, p. 275.

HUGHES, E. E., 1983, Geothermal rotary separator turbine: wellhead power system tests at Milford, Utah: Intersociety Energy Conversion Engineering Conference, Proceedings, v. 1, p. 280-285.

HULEN, J. B., 1978, Stratigraphy and alteration, 15 shallow thermal gradient holes, Roosevelt Hot Springs KGRA and vicinity, Millard and Beaver Counties, Utah: Earth Science Laboratory/University of Utah Research Institute Report, no. IDO/78-1701.b.1.1.1, 67 p.
Geologic setting, stratigraphy, petrography, and structure of the Roosevelt area; hot spring deposits; surface and subsurface alteration; methods and procedures for sample collection from 15 drill holes; local stratigraphy and alteration assemblages observed in drill cuttings; appendices include location and geologic maps of area, and lithologic, alteration, and mineralization logs from drill holes.

HULEN, J. B., and Sandberg, S. M., 1981, Exploration case history of the Monroe KGRA, Sevier County, Utah: Earth Science Laboratory/University of Utah Research Institute Report, no. DOE/ID/12079-22, 82 p.

Examines exploration techniques used to evaluate Monroe KGRA and their value in predicting resources; stratigraphy and structure of area; alteration and spring geochemistry; interpretation of gravity, magnetic, and resistivity surveys; temperature and lithologic logs from 11 shallow holes; test and production well drilling; maps of heat flow, gravity, magnetic, and resistivity surveys; gravity and magnetic profiles; resistivity models; isotherm cross sections; lithologic, temperature, and gammaray logs for test wells; tables of spring geochemical data.

HULEN, J. B., and Sibbett, B. S., 1981, Interpretation of drill cuttings from geothermal wells: Earth Science Laboratory/University of Utah Research Institute Report, no. DOE/ID/12079-36, 21 p.

Estimates configuration of geothermal reservoirs using drill cuttings; outlines procedures and problems associated with identification of lithology and alteration products in drill cuttings, and recognition of faults and fractures; procedures for collection, preparation, examination, and storage of samples.

ISHERWOOD, W. F., 1967, Regional gravity survey of parts of Millard, Juab, and Sevier Counties, Utah: Salt Lake City, Utah, University of Utah, unpublished Masters thesis, $31 \mathrm{p}$.

ISSELHARDT, C. F., Matlick, J. S., and Smith, J. L., 1977, Summary of 1976 geothermal drilling - western United States: Geothermal Energy, v. 5, no. 5, p. 8-17.

IVES, R. L., 1946, The Fish Springs area, Utah: Rocks and Minerals, v. 21 , no. 9 , p. $555-560$.

IVES, R. L., 1947, Fumarole Butte, Utah: Rocks and Minerals, v. 22, no. 10, p. 903-909.

Location and geography of Fumarole Butte area; general geology, stratigraphy, and geomorphology of area; lateral extent of cone; speculation on former extent of cone and its volume; description and temperature of escaping gases; description of several springs throughout area; dates of volcanic activity; local volcanic structures.

IYER, H. M., 1980, Magma chambers and geothermal energy: Technical Program, Abstracts, and Biographies, Fiftieth Annual International Meeting and Exposition, Society of Exploration Geophysicists, p. 111. 
IYER, Mahadeva, Robinson, R., and Evans, J. R., 1980, P-wave delays at two geothermal areas (abs.), in Geological Survey Research 1980: U.S. Geological Survey Professional Paper 1175, p. 215.

Results of analysis of P-wave residual data from Roosevelt Hot Springs geothermal area; size of low-velocity body under the region; results of a second P-wave study across the eastern Snake River Plain; age of oldest volcanism in the Snake River Plain.

JAMIN, M. E., 1982, Mobile laboratory; chemical analysis at geothermal sites (contract no. RP741-1): Sixth Annual Stanford Geothermal Conference and Workshop, Proceedings, p. 5.45-5.53.

JENSEN, M. L., and Qidwai, H., 1980?, Surface evidence of geothermal sites by mercury soil-gas collecting: Utah Geological and Mineral Survey, UGMS unpublished report, $23 \mathrm{p}$.

Approaches to the investigation of geothermal sites; methods for, and importance of, determining subsurface geology of geothermal areas; relationship of mercury to geothermal systems; mercury occurrences in geothermal areas throughout the world; thermodynamics of mercury; collecting techniques and equipment; graph showing the profile of mercury measurements at Roosevelt Hot Springs; results of a soil-gas sample collection at Midway, Utah; background mercury values in nongeothermal and non-mineralized areas; results of mercury soil-gas sampling at Crystal Springs; summary; recommendations for future studies.

JOHNSON, E. H., 1975, Resistivity and induced polarization survey of a basalt flow in a geothermal environment, western Utah: Salt Lake City, Utah, University of Utah, unpublished Masters thesis, $69 \mathrm{p}$.

Overview of potential use of geothermal energy as a power source; geothermal potential of Utah; two dipoledipole continuous sounding profiling resistivity IP lines across Fumarole Butte; map showing location of Fumarole Butte, geology, and hydrology; previous work in area; regional geology, stratigraphy, volcanic history, geothermal gradient, and hydrology; table showing chemical analyses of lavas from area; table showing chemical analyses of water from Abraham Hot Springs; resistivity arrays used; data results; conclusions.

KACZYNSKI, V. W., Wert, M. A., and LaBar, D. J., 1981, Utilization of geothermal effluents to create waterfowl wetlands: Geothermal Resources Council, Transactions, v. 5, p. 603-606.

KALISER, B. N., and Grey, D. C., 1970, Sulfur isotope determinations as a geohydrologic tool: Engineering Geology and Soils Engineering, Eighth Annual Symposium, p. 55-63.

KARLSSON, T., 1984, Geothermal heating system for the Children's Museum of Utah: National Technical Information Service Report, no. DOE/ID/12478-T2, 31 p.
KATZ, Lewis, 1977, Seismic emissions study Roosevelt Hot Springs, Milford, Utah (for Union Oil Company): Earth Science Laboratory/University of Utah Research Institute Open-File Report, no. UT/RHS/SEI-1, unpaginated.

Analysis of data acquired in study; interpretation of anomalies and comparison with other geophysical information; maps of Roosevelt Hot Springs KGRA resistivity and of tops of seismic emmissions anomalies for five stations.

KATZENSTEIN, A., and Jacobson, J. J., 1976, A dipoledipole resistivity survey of the Roosevelt Hot Springs prospect, Beaver County, Utah: Getty Oil Company Project, no. 76.120, $18 \mathrm{p}$.

Dipole-dipole resistivity survey of 15 line miles conducted over Roosevelt Hot Springs; method of dipole-dipole presentation; general geology of area; structural features and trends; table showing chemical analyses of Roosevelt Hot Springs' waters; results of drilling in area and of a prior electrical survey; resistivity pseudo-sections for five survey lines; dipole-dipole electrical resistivity survey location map; resistivity interpretation map and discussion; conclusions and recommendations.

KELLOGG, W. C., and Cook, K. L., 1979, Discussion and reply to discussion on: A summary of the geology, geochemistry, and geophysics of the Roosevelt Hot Springs thermal area, Utah: Geophysics, v. 44, no. 12, p. 2007-2011.

Discussion of article by Ward and others (1978); doubts expressed over computer-oriented geophysicists and their methods of interpretation; apparent deficiencies in aeromagnetic data, contour map, and corresponding interpretive geology from Ward and others (1978); Cook's rebuttal to Kellogg's criticisms of aeromagnetic data, map, and geology; presentation of additional magnetic information over the Bailey Ridge rhyolite flow; interpretation of a broad east-west trending magnetic low.

KEYS, W. S., 1979, Geothermal well logged at Roosevelt Hot Springs in Utah (abs.), in Geological Survey research 1979, 1980: U.S. Geological Survey Professional Paper 1150, p. 197-198.

Use of temperature, acoustic televiewer, acoustic caliper, mechanical caliper, and gamma spectra logs obtained from a geothermal production well to determine the location and orientation of fractures within the hydrothermal system.

KHATTAB, M. M., 1969, Gravity and magnetic surveys of the Grouse Creek Mountains and the Raft River Mountains area and vicinity, Utah and Idaho: Salt Lake City, Utah, University of Utah, unpublished Ph.D. thesis, $195 \mathrm{p}$.

KILTY, K. T., 1978, Aspects of forced convective heat transfer in geothermal systems: Salt Lake City, Utah, University of Utah, unpublished Masters thesis, $61 \mathrm{p}$. 
KILTY, K. T., 1980, Deformation of the western United States and its thermal consequences (abs.): EOS Transactions, American Geophysical Union, v. 61, no. 46, p. 1124.

KILTY, K. T., Chapman, D. S., and Mase, C. W., 1978, Aspects of forced convective heat transfer in geothermal systems: Earth Science Laboratory/University of Utah Research Institute Report, no. IDO/78-1701.a.6.4.1, $62 \mathrm{p}$.

KILTY, K. T., Chapman, D. S., and Mase, C. W., 1979, Forced convective heat transfer in the Monroe Hot Springs geothermal system: Journal of Volcanology and Geothermal Research, v. 6, no. 3-4, p. 257-277.

Definition of problem and purpose of study; mathematical and conceptual models of heat transfer; general numerical solution of the energy equation; organization of numerical algorithm to accept ground-water flows, thermal conductivities, and boundary conditions; accuracy and rate of convergence of the algorithm; problems associated with estimating the film coefficient from wind speeds; dimensionless energy equation; origination and migration of thermal waters in model of a faultcontrolled geothermal system; application of convective heat transfer theory to model; graph showing relationship between heat flow enhancement directly over a fracture and the Peclet number of the model; geology and hydrology of study area; hot springs occurrences, temperatures, and salinity; graph showing temperaturedepth curves at Monroe Hot Springs and Red Hill Hot Springs; mixing of hot and cold waters and speculation on mixing location; fault permeability estimates; graph of numerically determined curves of heat-flow enhancement as a function of distance from the hot springs; implications for Monroe-Red Hill springs.

KLAUK, R. H., 1982, Geothermal energy, another of Utah's abundant resources: Utah Geological and Mineral Survey, Survey Notes, v. 16, no. 4, p. 1-8.

Classification of geothermal energy systems and their heat sources; mechanics of convective and conductive geothermal systems; geothermal resource map of Utah showing 327 thermal wells, springs, and nine KGRAs; location and characteristics of the Roosevelt KGRA; involvement of Phillips Petroleum Company in the development of Roosevelt KGRA; location and characteristics of Cove Fort-Sulphurdale KGRA; exploration conducted in the Whirlwind Valley area; uses for lowtemperature thermal water; summaries of studies conducted by the Utah Geological and Mineral Survey in Cache Valley, Escalante Valley, Box Elder County, Weber and Davis Counties, Salt Lake County, and the Utah State Prison space heating program.

KLAUK, R. H., 1985, Summary of low-temperature geothermal studies conducted by the Utah Geological and Mineral Survey from July 1, 1977 to December 31, 1984: Utah Geological and Mineral Survey Report of Investigation, no. $193,16 \mathrm{p}$.
Summary and results of state-wide geothermal studies; map showing geothermal resources of Utah; specific studies of known hot spring areas conducted by the Utah Geological and Mineral Survey; methods used and results; area-wide studies conducted for the purpose of detecting unknown geothermal systems; summaries of tests and results of studies in Escalante Valley, Cache Valley, north-central Box Elder County, Box Elder County, Weber and Davis Counties, Salt Lake and Utah Counties; other UGMS geothermal contributions.

KLAUK, R. H., and Budding, K. E., 1984, Geothermal assessment of the lower Bear River drainage and northern East Shore ground-water areas, Box Elder County, Utah: Utah Geological and Mineral Survey Report of Investigation, no. $186,98 \mathrm{p}$.

General geology and structure of study area; hydrologic setting of lower Bear River drainage basin and East Shore area; locations and descriptions of known hot springs in study area; temperature survey of 52 wells and of several spring locations; water chemistry and analyses of common ion and trace elements; use of geothermometry to calculate reservoir temperatures; temperature versus depth measurements and geothermal gradients; maps of geology, known thermal springs, and sample locations; table of water analyses from wells in the study area.

KLAUK, R. H., and Darling, R., 1984, Low-temperature geothermal assessment of the Jordan Valley, Salt Lake County, Utah: Utah Geological and Mineral Survey Report of Investigation, no. $185,160 \mathrm{p}$.

Description of project; physiographic setting of the Jordan Valley; regional and local geology and geophysics; ground water; four different aquifer types; water recharge and movement; Warm Springs fault, Crystal Hot Springs, and Utah Roses Floral Greenhouse geothermal systems; temperature survey of 223 locations; chemical analyses of 199 water samples including total dissolved solids, common ion analysis, and trace element determinations; chemical geothermometers calculated for all water samples; temperature gradients derived from temperature-depth measurements; summary and conclusions.

KLAUK, R. H., Darling, R., Davis, D. A., Gwynn, J. W., and Murphy, P. J., 1981, Progress report on the geothermal assessment of the Jordan Valley, Salt Lake County, Utah, in Ruscetta, C. A., and Foley, D., eds., Geothermal direct heat program Glenwood Springs technical conference proceedings; State Coupled Geothermal Assessment Program: Earth Science Laboratory/University of Utah Research Institute Report, no. DOE/ID/12079-39, v. 1, Papers Presented, p. 271-296.

See Klauk and Darling (1984).

KLAUK, R. H., and Davis, D. A., 1984, Evaluation of lowtemperature geothermal potential in Utah and Goshen Valleys and adjacent areas, Utah County, Utah, Part II: 
water temperature and chemistry: Utah Geological and Mineral Survey Report of Investigation, no. 191, 45 p.

History of Utah Geological and Mineral Survey geothermal investigations along Wasatch Front; description of Parts I and II of study; types of ground water reservoirs (confined and unconfined aquifers); migration paths of ground waters; water sampling tests and procedures; plates showing ground water temperatures and sample locations of 67 wells and springs in Utah and Goshen Valleys; ranges of water sample temperatures; tables showing results of chemical analyses of 68 water samples; comparison of chemical analyses and trace element studies of waters in northern Utah Valley and Goshen Valley; table showing measured temperatures, $\mathrm{Cl} / \mathrm{HCO} 3$ ratios, $\mathrm{Li}, \mathrm{B}, \mathrm{Sr}$, and $\mathrm{Cl}$ concentrations for wells and springs; five areas identified for further investigations; model depicting convective system of thermal waters in study area.

KLAUK, R. H., Foreman, M. B., and Gourley, C., 1982, Geothermal reconnaissance of a portion of the Escalante Valley, Utah, in Ruscetta, C. A., ed., Geothermal direct heat program roundup technical conference proceedings; State Coupled Resource Assessment Program: Earth Science Laboratory/University of Utah Research Institute Report, no. DOE/ID/12079-71, v. 1, Papers Presented, p. 240-272.

See Klauk and Gourley (1983a).

KLAUK, R. H., and Gourley, C., 1983a, Geothermal assessment of a portion of the Escalante Valley, Utah: Utah Geological and Mineral Survey Special Studies 63, $57 \mathrm{p}$.

Stratigraphy, igneous rocks, and structure of the Escalante Valley and vicinity; known geothermal areas; ground water temperatures; water chemistry including analyses of total dissolved solids, common ions, and silica; chemical geothermometer calculations; temperature versus depth measurements and geothermal gradients; proposed models for an anomalous geothermal area northwest of Zane; maps of gravity, ground-water temperatures, potentiometric surface, hydrologic units, geology, total dissolved solids, and sampling sites.

KLAUK, R. H., and Gourley, C., 1983b, Geothermal assessment of a portion of the MX deployment area, Escalante Valley, Utah (abs.): Geological Society of America Abstracts with Programs, v. 15, no 5, p. 416.

See Klauk and Gourley (1983a).

KLAUK, R. H., and Prawl, C. A., 1984, Geothermal assessment of part of the East Shore area, Davis and Weber Counties, Utah: Utah Geological and Mineral Survey Report of Investigation, no. 183, 46 p.

Purpose of study; geology, structure, and ground water conditions of the study area; describes known geothermal areas; temperature survey; water chemistry and analyses of common ions, stable isotopes, and trace elements; calculated geothermometer temperatures; maps of geology, ground water temperatures, well and spring sample locations, total dissolved solids, and chloride ion concentrations; table of water analyses from wells in study area.

KNAUF, K. E., 1981, National estimate for direct use: Geothermal Resources Council, Transactions, v. 5, p. 527-530.

KOENIG, J. B., 1971, Geothermal exploration in the western United States in, Proceedings of the United Nations Symposium on the development and utilization of geothermal resources: Geothermics Special Issue 2, 1970 , v. 2 , pt. 1, p. 1-13.

KOENIG, J. B., Anderson, D. N., and Huttrer, G. W., 1976, Exploration and development of geothermal resources in the United States, 1968-1975: United Nations symposium on the development and use of geothermal resources, 2d, San Francisco, California, 1975, Proceedings, v.1, p. 139-142.

KOENIG, J. B., and McNitt, J. R., 1983, Controls on the location and intensity of magmatic and non-magmatic geothermal systems in the Basin and Range Province (abs.), in The role of heat in the development of energy and mineral resources in the northern Basin and Range Province: Geothermal Resources Council Special Report 13, p. 93.

Relationship of geothermal systems of known or probable magmatic control to the Basin and Range Province; characteristics of magmatic geothermal systems; relationship of high-temperature, non-magmatic systems to important northeast-trending zones of topographic flexures; heat source for non-magmatic systems.

KOENIG, J. B., and Petersen, C. A., 1977, Opportunities for development of geothermal power at Roosevelt Hot Springs, Utah: GeothermEx Incorporated, $36 \mathrm{p}$.

Location of the Roosevelt geothermal field; regional and local geology; map showing geology, temperature gradients, gravity anomalies, and geothermal wells; map showing fractures interpreted from resistivity; petrographic descriptions and age dates of local intrusives and volcanics; gravity, telluric, aeromagnetic, resistivity, microearthquake, and temperature gradient data; exploration history and results; table of geothermal well locations, depths, and drilling results; field size and capacity, heat source, and reservoir studies; map of geothermal leasing patterns in the Roosevelt area; environmental concerns; production and development risks; conclusions.

KOHLER, J. F., 1979, Geology, characteristics, and resource potential of the low-temperature geothermal system near Midway, Wasatch County, Utah: Utah Geological and Mineral Survey Report of Investigation, no. 142,64 p.

See Kohler and Kolesar (1979). 
KOHLER, J. F., and Kolesar, P. T., 1979, Evaluation of geothermal potential in the area of Midway, Wasatch County, Utah: Geothermal Resources Council, Transactions, v. 3, p.349-352.

Geologic setting of Midway, Utah; chemical analysis and geothermometry of thermal waters; thermal gradient determinations based on four drill holes and one mine shaft; central gravity low at Midway; two opposing heat source models.

KOLESAR, P. T., and Degraff, J. V., 1977, Comparison of the silica and Na-K-Ca geothermometers for thermal springs in Utah: Geothermics, v. 6, no. 3-4, p. 221-226.

KRON, Andrea, and Heiken, G., 1980, Geothermal gradient map of the United States: Geothermal Resources Council, Transactions, v. 4, p. 69-72.

KRON, Andrea, and Stix, J., 1982, Geothermal gradient map of the United States exclusive of Alaska and Hawaii: Map produced by the National Oceanic and Atmospheric Administration for the Los Alamos National Laboratory, scale 1:2,500,000; also, Geothermal Resources Council, Transactions, v. 6, p. 35-38.

KRUGER, Paul, and Semprini, L., 1983, Radon startup analysis at a Roosevelt Hot Springs, Utah geothermal well: Seventh Annual Stanford Geothermal Conference and Workshop, Proceedings, p. 5.87-5.93.

KUNZE, J. F., and Gould, R. W., 1981, Case studies of developing low-temperature geothermal wells: Geothermal Resources Council, Transactions, v. 5, p. 251-252.

KUNZE, J. F., Gould, R. W., and Gertsch, W. D., 1980, Utah Roses floral greenhouse geothermal project: semiannual technical report, August 1979 - April 1980: U.S. Department of Energy Report, no. DOE/ET/27056/3, $43 \mathrm{p}$.

KUNZE, J. F., and Stoker, R. C., 1979, Floral greenhouse heating; semi-annual technical report: National Technical Information Service Report, no. DOE-27056-2, 57 p.

LACHENBRUCH, A. H., 1978, Heat flow in the Basin and Range Province and thermal effects of tectonic extension, in Rybach, L., and Stegena, L., eds., Geothermics and geothermal energy: Pure and Applied Geophysics, v. 117, p. $34-50$.

LACHENBRUCH, A. H., 1980, Regional thermal structure in the western U.S. (abs.): EOS Transactions, American Geophysical Union, v. 61, no. 46, p. 1144.

LACHENBRUCH, A. H., and Sass, J. H., 1977, Heat flow in the United States and the thermal regime of the crust, in Heacock, J. G., ed., The earth's crust: Geophysical Monograph Series, v. 20, American Geophysical Union, Washington, D. C., p. 626-675.

LACHENBRUCH, A. H., and Sass, J. H., 1978, Models of an extending lithosphere and heat flow in the Basin and Range Province, in Smith, R. B., and Eaton, G. P., eds., Geological Society of America Memoir 152, p. 209-250.
LADD, T. A., 1980, Institutional problems related to development of geothermal resources located within department of defense land holdings: Geothermal Resources Council, Transactions, v. 4, p. 803-806.

LANGE, A. L., 1976, Application of heatflux transducers to geothermal exploration: Symposium on Rock Mechanics, 17, Proceedings, p. 3B2.1-3B2.6.

LASTER, S. J., and Douze, E. J., 1978, Geothermal ground noise measurements at Roosevelt Hot Springs and Cove Fort, Utah-final report: National Technical Information Service Report, no. DOE/TIC-11062, 94 p.

Use of six element arrays to determine the structure of the noise field and types of waves present in Roosevelt and Cove Fort geothermal areas; array configuration; theory of array processing; analysis of experimental data obtained from frequency-wave number spectra, power spectra, and f-statistic analytical techniques.

LEE, W. T., 1907, Sulphur and pyrite-The Cove Creek sulphur beds, Utah: U.S. Geological Survey Bulletin 315-Q, p. Q485-Q489.

LEEMAN, W. P., and Rogers, J. J. W., 1970, Late Cenozoic alkali-olivine basalts of the Basin and Range Province, U.S.A.: Contributions to Mineralogy and Petrology, v. 25, p. 1-24.

LEITNER, Phillip, 1978, Overview of environmental issues: Roosevelt Hot Springs KGRA, Utah geothermal noise effects: National Technical Information Service Report, no. UCRL-13995, 11 p.

Geography of region around Roosevelt Hot Springs; ambient noise of study area; measured sound-pressure levels from well-venting operations at the GeysersCalistoga KGRA; low noise emmissions at Roosevelt and other liquid-dominated geothermal fields; summary of noise sources expected to accompany geothermal resource development in southwest Utah; procedures for a planned one year ambient noise survey at Roosevelt; noise receptor sites; noise propagation models; community, domestic livestock, and wildlife noise criteria; recommendations to aid in assessing the potential for environmental noise problems from geothermal resource development in southwest Utah.

LENZER, R. C., Crosby, G. W., and Berge, C. W., 1976, Geothermal exploration of Roosevelt KGRA, Utah: U.S. Symposium on Rock Mechanics, no. 17, Site Characterization, University of Utah Engineering Experimental Station, p. 3B1-1.

Location, structural geology, and petrology of the Roosevelt geothermal field; rhyolites from seven or more eruptive centers; faults as control structures for hydrologic systems; methods of investigation; geometry and geologic interpretation of area around the thermal anomaly; permeability of fractures; drill hole structure and temperatures. 
LIAW, A. L., and Suyenaga, W., 1982, Microtremor studies in Roosevelt and Beowawe geothermal areas (abs.), in Circum-Pacific energy and mineral resources conference: American Association of Petroleum Geologists Bulletin, v. 66, no. 7, p. 975 .

Use of microtremors as indicators of geothermal reservoirs; discussion of controversy over methods; two passive seismic studies conducted in Basin and Range; procedures and results of a microtremor study at Beowawe, Nevada.

LIAW, A. L., and Suyenaga, W., 1983, Detection of geothermal microtremors using seismic arrays (abs.): Geophysics, v. 48, no. 4 , p. 479.

LIESE, H. C., 1957, Geology of the northern Mineral Range, Millard and Beaver Counties, Utah: Salt Lake City, Utah, University of Utah, unpublished Masters thesis, $88 \mathrm{p}$.

LIN, Y. T., 1981, The impact of bit performance on geothermal well cost: Geothermal Resources Council, Transactions, v. 5, p. 253-256.

LIPMAN, P. W., 1979, Cenozoic volcanism in the western United States: implications for continental tectonics, in Continental Tectonics/geophysics study committee, geophysics research board, assembly of mathematical and physical sciences, National Research Council: National Academy of Science, Washington D. C., 1980, p. 1-14.

LIPMAN, P. W., Prostka, H. J., and Christiansen, R. L., 1972, Cenozoic volcanism and plate-tectonic evolution of the western United States: Philosophical Transactions of the Royal Society of London, s. A 271, p. 217-248.

LIPMAN, P. W., Rowley, P. D., Mehnert, H. H., Evans, S. H., Jr., Nash, W. P., and Brown F. H., 1978, Pleistocene rhyolite of the Mineral Mountains, Utah; geothermal and archaeological significance: U.S. Geological Survey Journal of Research, v. 6, no. 1, p. 133-147.

Use of silicic rocks as indicators of subsurface presence of shallow magma chambers with potential geothermal resources; purpose of study; general geologic setting of Mineral Mountains; K-Ar dates and a Rb-Sr isochron from Mineral Mountains intrusives; thermal measurements from neighboring Roosevelt Hot Springs; stratigraphy, petrography, and ages of three distinct rhyolitic sequences; table showing modal compositions of radiometrically dated volcanics; table showing chemical analyses and CIPW norms of rhyolites of the Mineral Mountains; table showing K-Ar age determinations on upper Cenozoic rhyolites of area; table showing preliminary data on magnetic polarities of rhyolites; table showing rare-earth element analyses of rhyolites; discussion of possible relationships between Mineral Mountain rhyolites and potential geothermal resources; archeological artifact obsidian from Mineral Mountains; fission track dating on obsidians; obsidian-hydration dating on four rhyolite flows.
LIPMAN, P. W., Rowley, P. D., and Pallister, J. S., 1975, Pleistocene rhyolite of the Mineral Range, Utah geothermal and archeological significance (abs.): Geological Society of America Abstracts with Programs, v. 7, no. 7, p. 1173.

See Lipman and others (1978).

LORING, A. K., 1972, Temporal and spatial distribution of Basin-Range faulting in Nevada and Utah: Los Angeles, California, University of Southern California, unpublished Masters thesis, $163 \mathrm{p}$.

LOVELL, J. S., Meyer, W. T., and Atkinson, D. J., no date, Geology and surface geochemistry of the Roosevelt springs known geothermal resource area, Utah: National Technical Information Service Report, no. DOE/ID/12062-T1, $550 \mathrm{p}$.

Synthesis of available data on Roosevelt Hot Springs to determine the spatial arrangement of rocks and the pattern of mass and energy flow within them; temperature gradient and heat flow patterns; distribution of lithologies obtained from deep drilling; shallow ground water chemistry and flow patterns; regional geologic setting; stratigraphy; distribution of fault structures in Milford Valley; reservoir configuration and origin of thermal fluids; temperature distribution and convective circulation; gas and liquid discharge compositions; multielemental analysis of soil samples to $300 \mathrm{feet}$, and of reservoir caprock; geochemical patterns from earlier stages of geothermal evolution; detailed surface microlayer traverses for selected elemental distribution and single element contour maps; factor analysis of single element distribution and resulting contour maps of nine geochemical parameters.

LOVERING, T. S., 1965, Some problems in geothermal exploration: Society of Mining Engineers, Transactions, v. 232, no. 3, p. 274-281; also, (excerpts) Mining Engineering, v. 17 , no. 9 , p. 95-99.

LOVERING, T. S., and Goode, H. D., 1963, Measuring geothermal gradients in drill holes less than 60 feet deep, East Tintic district, Utah: U.S. Geological Survey Bulletin 1172, 48 p.

Factors that determine temperature fluctuations at and near the earth's surface; methods used to determine geothermal gradients; drill hole temperatures in the Tintic area; effect of sun on near-surface temperatures; table showing thermal diffusivities of rocks from study area; effect of fluctuation in the amount of incoming solar heat; temperature measurements from 58 drill holes in various lithologies; field procedures; air and ground temperatures for background data; diffusivity calculations from subsurface temperature measurements; summary and project evaluation.

LOVERING, T. S., and Morris, H. T., 1965, Underground temperatures and heat flow in the East Tintic district, Utah: U.S. Geologic Survey Professional Paper 504-F, p. F1-F28. 
Location and history of the East Tintic mining district; factors affecting surface temperatures; procedures and instruments for measuring temperature gradients in drill holes; effects of drilling on gradient measurements; difficulties associated with accurately measuring temperatures in mines; relationships of thermal conductivity, temperature gradient, and heat flow; heat flow and thermal gradients in uniform rocks; direct and indirect determination of conductivity of rocks; geologic factors involved in temperature calculations; calculation of temperatures at the water table; temperature fluctuations within the Tintic district; sources of heat; table showing chemical analyses of water from Eureka city well, Bergin Mine, North Lily Mine, and saline hot springs of Utah with temperatures above 115 degrees $\mathrm{F}$; heat flow estimates of subterranean hot springs; origin of thermal waters; geology, structure, geothermal gradient, and thermal conductivities in the Latite Ridge thermal area.

LOWDER, G. G., 1973, Late Cenozoic transitional alkali olivine-tholeiitic basalt and andesite from the margin of the Great Basin, southwest Utah: Geological Society of America Bulletin, v. 84, no. 9, p. 2993-3012.

LUEDKE, R. G., and Smith, R. L., 1978, Map showing distribution, composition, and age of late Cenozoic volcanic centers in Colorado, Utah, and southwestern Wyoming: U.S. Geological Survey Miscellaneous Investigation Series Map 1-1091-B, scale 1:1,000,000.

LUNIS, B. C., and Toth, W. J., 1982, State geothermal commercialization programs in seven Rocky Mountain states: semiannual progress report, January-July 1981: National Technical Information Service Report, no. DOE/ID/12101-4, 226 p.

LUTH, W. C., and Hardee, H. C., 1980, Comparative assessment of five potential sites for hydrothermal-magma systems; summary: Department of Energy Report, no. DOE/TIC-11303, $51 \mathrm{p}$.

LYNCH, W. C., and Nash, W. P., 1980, Chemical trends in the Ice Springs basalt, Black Rock Desert, Utah: Earth Science Laboratory/University of Utah Research Institute Report, no. DOE/ID/12079-12, 96 p.

MABEY, D. R., Oliver, H. W., and Hildenbrand, T. G., 1983, Regional gravity and magnetic anomalies in the northern Basin and Range Province, in The role of heat in the development of energy and mineral resources in the northern Basin and Range Province: Geothermal Resources Council Special Report 13, p. 307-316.

MABEY, D. R., and Virgin, V., 1980, Composite aeromagnetic map of the Richfield $1 \times 2$ degree quadrangle, Utah: U.S. Geological Survey Open-File Report 80-242, scale $1: 250,000$.

MABEY, D. R., Zietz, I., Eaton, G. P., and Kleinkopf, M. D., 1978, Regional magnetic patterns in part of the Cordillera in the western United States, in Smith, R. B. and Eaton, G. P., eds., Cenozoic tectonics and regional geophysics of the western Cordillera: Geological Society of America Memoir 152, p. 93-106.

MACHETTE, M. N., 1982, Guidebook to the late Cenozoic geology of the Beaver basin, south-central Utah: U.S. Geological Survey Open-File Report 82-850, 42 p.

MACHETTE, M. N., Steven, T. A., Cunningham, C. G., and Anderson, J. J., 1984, Geologic map of the Beaver quadrangle, Beaver and Piute Counties, Utah: U.S. Geological Survey Miscellaneous Investigations Series Map I-1520, scale 1:50,000.

MACKIN, J. H., 1960a, Eruptive tectonic hypothesis for origin of Basin-Range structure (abs.): Geological Society of America Bulletin, v. 71, no. 12, pt. 2, p. 1921.

MACKIN, J. H., 1960b, Structural significance of the Tertiary volcanic rocks in southwestern Utah: American Journal of Science, v. 258, no. 2, p. 81-131.

MAINZER, G. F., 1978, Gravity and aeromagnetic patterns in the Basin and Range-Colorado Plateau transition in southwestern Utah and northwestern Arizona: Salt Lake City, Utah, University of Utah, unpublished Masters thesis, $161 \mathrm{p}$.

MARINER, R. H., Brook, C. A., Reed, M. J., Bliss, J. D., Rapport, A. L., and Lieb, R. J., 1983, Low-temperature geothermal resources in the western United States, in Reed, M. J., ed., Assessment of low-temperature geothermal resources of the United States-1982: U.S. Geological Survey Circular 892, p. 31-50.

Assessment of low-temperature geothermal systems; distribution, geologic setting, and division into geologic provinces - including the Basin and Range Province; determination of accessible resource base, resource, and beneficial heat; estimation of temperature, area, and volume of geothermal reservoir; maps of lowtemperature geothermal systems; tables of summaries of the identified and undiscovered accessible resource bases, and energies of low-temperature geothermal systems (22 are in Utah).

MARINER, R. H., Brook, C. A., Swanson, J. R., and Mabey, D. R., 1978, Selected data for hydrothermal convection systems in the United States with estimated temperatures greater than or equal to 90 degrees C: back-up data for U.S. Geological Survey Circular 790: U.S. Geological Survey Open-File Report 78-858, 493 p.

Explanation of data sheets containing field name, location, general information, chemistry, geothermometers, heat and steam losses, temperatures, reservoir properties, and thermal energy calculations; Utah data sheets on Abraham Hot Springs, Monroe-Red Hill, Joseph Hot Springs, Cove Fort- Sulphurdale, Roosevelt Hot Springs, Thermo Hot Springs, and Newcastle.

MARINER, R. H., Presser, T. S., and Evans, W. C., 1977, Chemical, isotopic, and gas compositions of selected thermal springs in Arizona, New Mexico, and Utah: U.S. Geological Survey Open-File Report 77-654, 42 p. 
Chemical analyses of thermal water samples from Crater Springs, Thermo, Monroe-Red Hill, and Joseph KGRAs; methods and procedures of sampling; calculations of solution-mineral equilibrium; tables of major element spring chemistry, minor- and trace-element chemistry, gas composition, isotopic compostion, and estimated thermal aquifer temperature.

MARINER, R. H., Presser, T. S., and Evans, W. C., 1983, Geochemistry of active geothermal systems in the northern Basin and Range Province, in The role of heat in the development of energy and mineral resources in the northern Basin and Range Province: Geothermal Resources Council Special Report 13, p. 95-120.

Chemical composition of Basin and Range thermal waters; map showing distribution of $\mathrm{Na}-\mathrm{Cl}$ waters in the northern Basin and Range; relationship of $\mathrm{Na}$ mixed anion waters to geologic strata; chemical composition and possible origin of thermal spring gases; table showing geothermometer temperatures based on the chemical composition of waters from hot springs and shallow wells; list of expected and measured temperatures of geothermal systems in the northern Basin and Range; contour map of the deuterium composition of northern Basin and Range thermal springs; table showing isotopic data for thermal springs; Abraham and Thermo Hot Springs anhydrite saturation temperatures and sulfate-water isotope equilibrium temperatures.

MARSELL, R. E., 1951, Groundwater contamination by saline thermal waters (abs.): Geological Society of America Bulletin, v. 62, no. 12, pt. 2, p. 1506-1507.

MASE, C. W., 1979, Geophysical study of the Monroe-Red Hill geothermal system: Salt Lake City, Utah, University of Utah, unpublished Masters thesis, $108 \mathrm{p}$.

See Mase, Chapman, and Ward (1978).

MASE, C. W., and Chapman, D. S., 1978, Geophysical study of the Monroe, Utah geothermal system (abs.): Geological Society of America Abstracts with Programs, v. 10, no. 5, p. 233.

See Mase, Chapman, and Ward (1978).

MASE, C. W., Chapman, D. S., and Ward, S. H., 1978, Geophysical study of the Monroe-Red Hill geothermal system: University of Utah, Department of Geology and Geophysics Report, no. 77-8, 89 p.

Geology and structure of study area; geologic model for Monroe system; total magnetic map and interpretation; gravity profile across Monroe system and interpretation; dipole-dipole resistivity map and interpretation; geothermal gradient data including temperature-depth curves and isothermal cross section; appendices of magnetic, gravity, geothermal gradient, heat flow, and dipoledipole resistivity data.

MATHEWS, M. A., 1979, Log responses from the geothermal calibration test well C/T2: Society of Petroleum Well-Log Analysts, 20th Annual Symposium, Paper no. SS, 1 p.
MATHEWS, M. A., and LaDelfe, C., 1981, Log compar1son and quantification: Transactions of the CWLS Formation Evaluation Symposium, 8th, p. 16.

MATLICK, J. S., and Shiraki, M., 1981, Evaluation of the mercury soil mapping geothermal exploration technique: Geothermal Resources Council, Transactions, v. 5, p. 95-98.

Comparison of thermal gradient anomalies with mercury soil anomalies at northern Dixie Valley, Nevada, Roosevelt Hot Springs, Utah, and Noya, Japan; location, general geology, thermal gradient anomalies, and mercury soil concentration distributions and ranges at Roosevelt, Dixie Valley, and Noya; map showing temperature gradients and mercury soil concentrations at Roosevelt Hot Springs; discussions and conclusions.

MATLICK, J. S., and Smith, J. L., 1976, Summary of 1975 geothermal drilling, western United States: Geothermal Energy, v. 4, no. 6, p. 28-31.

MCHUGH, J. B., Ficklin, W. H., and Miller, W. R., 1980, Analytical results for 50 water samples from Beaver Valley, Utah: U.S. Geological Survey Open-File Report 80-517, 15 p.

MCHUGH, J. B., Ficklin, W. H., and Miller, W. R., 1981, Analytical results for 30 water samples from Mineral Mountains, Utah: U.S. Geological Survey Open-File Report 81-96, 8 p.

MCHUGH, J. B., Ficklin, W. H., Miller, W. R., and Preston, D. J., 1981, Analytical and statistical results for 486 water samples from the Richfield $1 \times 2$ degree quadrangle, Utah: U.S. Geological Survey Open-File Report 81-731, $31 \mathrm{p}$.

MCHUGH, J. B., and Miller, W. R., 1981, Analytical results for 50 water samples from Milford basin, Utah: U.S. Geological Survey Open-File Report 81-729, 15 p.

MCHUGH, J. B., and Miller, W. R., 1982, Radon survey of ground waters from Beaver and Milford basins, Utah: U.S. Geological Survey Open-File Report 82-382, 13 p.

MCHUGH, J. B., Miller, W. R., and Ficklin, W. H., 1984, Map showing distribution of $\mathrm{pH}$, copper, zinc, fluoride, uranium, molybdenum, arsenic, and sulfate in water, Richfield 1x2 degree quadrangle, Utah: U.S. Geological Survey Miscellaneous Field Studies Map MF-1246-L, scale 1:500,000.

MCHUGH, J. B., Motooka, J. M., and Tucker, R. E., 1980, Analytical results for 122 water samples from Beaver Valley, Utah: U.S. Geological Survey Open-File Report 80-820, 21 p.

MCKINNEY, D. B., 1978, Annotated bibliography of the geology of the Roosevelt Hot Springs known geothermal area and the adjacent Mineral Mountains, March 1978: Earth Science Laboratory/University of Utah Research Institute Report, no. DOE/ET/28392-10, 15 p. 
MCNITT, J. R., 1965, Review of geothermal resources (in terrestrial heat flow): American Geophysical Union, Geophysical Monograph Series, no. 8, ch. 9, p. 240-266.

MEHNERT, H. H., Rowley, P. D., and Lipman, P. W., $1978, \mathrm{~K}-\mathrm{Ar}$ ages and geothermal implications of young rhyolites in west-central Utah: Isochron/West, no. 21, p. 3-7.

Fourteen new K-Ar ages determined for alkalic rhyolites from west-central Utah; three mappable units of Mineral Mountains rhyolite and their relative ages; petrology, volcanic history, extent, and ages of Black Rock Desert rhyolites; ages of four rhyolites forming an east-trending structural lineament; known ages of nearby alkalic basalts; sample locations and analytical data; table showing modes of young rhyolites in west-central Utah.

MEIDAY, H. T., and Sanyal, S., 1976, Comparison of hydrothermal reservoirs of the western United States, topical report 3: National Technical Information Service Report EPRI-ER-364 (12-76), 174 p.

MEIIJI Resource Consultants, 1983, Gravity based interpretive bedrock geology of the Jordan Valley, Salt Lake County, Utah: Utah Geological and Mineral Survey Open-File Report, no. 38, 22 p.

MEINZER, O. E., 1924, Origin of the thermal springs of Nevada, Utah, and southern Idaho: Journal of Geology, v. 32, no. 4, p. 295-303.

MEYER, R. T., and Bronder, L. D., 1980, Evaluation of state taxes and tax incentives and their impact on the development of geothermal energy in western states: Geothermal Resources Council, Transactions, v. 4, p. 739.742.

MEYER, R. T., Watson L. D., Nasr, L., and Gertsch, W. D., 1979, Small business participation in geothermal energy development: recommendations for the geothermal onmibus bill: Geothermal Resources Council, Transactions, v. 3, p. 453-456.

MICRO GEOPHYSICS, 1977, Refraction shooting near Roosevelt Hot Springs - data: University of Utah, Department of Geology and Geophysics Report, no. $77-4,56 \mathrm{p}$.

Data from large-scale refraction program over geothermal anomaly at Roosevelt Hot Springs.

MIFFLIN, M. D., 1983, Regional hydrology in the northern Basin and Range Province (abs.), in The role of heat in the development of energy and mineral resources in the northern Basin and Range Province: Geothermal Resources Council Special Report 13, p. 9.

MILLER, B. M., 1975, The application of trend surface analysis to geothermal and geopressure data in petroleum exploration (abs.): American Association of Petroleum Geologists and Society of Economic Paleontologists and Mineralogists, Annual Meeting, Abstracts, v. 2, p. 51 .
MILLER, C. D., 1976, Alteration and geochemistry of the Monroe known geothermal resource area: Salt Lake City, Utah, University of Utah, unpublished Masters thesis, $120 \mathrm{p}$.

Purpose of study; geology, geography, and Tertiary volcanic history of Monroe KGRA; three square miles mapped on aerial photo base $(1: 4,800)$; maps showing geology, hydrothermal alteration, and sample locations; stratigraphy of area; temperature ranges of local springs; description of surface alteration; methods of petrographic analysis; map showing distribution of sulfate minerals, montmorillonite, and biotite containing sagenitic rutile; common primary rock textures; alteration assemblages; multivariate analysis of rock alteration; methods for analyzing spring geochemistry; calculation of ion activities; theory on origin of the Monroe spring water; model for heat flow; alteration geochemistry and thermodynamics; conclusions.

MILLER FLORAL COMPANY, 1977, A demonstration project for geothermal heating of greenhouses, Utah: Utah Roses Incorporated, $16 \mathrm{p}$.

MILliGAN, J. H., 1967, Mineralized springs and their effect on Utah's groundwater supplies, in Groundwater development in arid basins - a symposium: Utah State University, Proceedings, p. 43-50.

MILligAN, J. H., Marselli, R. E., and Bagley, J. M., 1966, Mineralized springs in Utah and their effect on manageable water supplies: Utah State University, Utah Water Research Laboratory Report WG23-6, 50 p.

MONROE CITY, Utah - Municipality, 1977, Proposal for direct utilization of geothermal resources field experiments at Monroe, Utah: Monroe City, P.O. Box A, Monroe, Utah 84754 , v. 1 Technical Proposal and v. 2 Business Proposal, $117 \mathrm{p}$.

Proposal to the U.S. Department of Energy from Monroe City to develop a district heating plan using the Monroe KGRA; outline of development of the heating system; status of geothermal rights, rights of way, and ownership at the Monroe KGRA; location and general geology of Monroe; project objectives; proposed utility management and key personnel; Monroe City financial statements; letters from banks, businesses, etc. encouraging geothermal power development; identification of user groups; energy demands; system design; magnetic, gravity, resistivity, and seismic surveys; thermal gradient measurements; production potential; environmental, institutional, legal, and social considerations; program budget; projected cash flow requirements.

MONTGOMERY, J. R., 1973, Regional gravity study of western Utah: Salt Lake City, Utah, University of Utah, unpublished $\mathrm{Ph} . \mathrm{D}$. thesis, $142 \mathrm{p}$.

MOORE, J. N., 1980a, A summary of the geochemistry of the Roosevelt Hot Springs geothermal system, in Nielson, D. L., ed., Geothermal systems in central Utah: Geothermal Resources Council Annual Meeting, Salt 
Lake City, Utah, Guidebook to Field Trip, no. 7, p. 30-35.

Location and Quaternary volcanism of Roosevelt Hot Springs; geothermal fluid chemistry; chemical variations within the system; table showing fluid chemistries and calculated temperatures of reservoir fluids; flow patterns of thermal fluids; mineralogy and alteration of reservoir rocks; two distinct hydrothermal alteration assemblages; maps showing distribution of mercury and arsenic in soils over the thermal area.

MOORE, J. N., 1980b, Geology of the Cove FortSulphurdale KGRA, in Nielson, D. L., ed., Geothermal systems in central Utah: Geothermal Resources Council Annual Meeting, Salt Lake City, Utah, Guidebook to Field Trip, no. 7, p. 14-17.

Location, historical geology, and petrology of the Cove Fort-Sulphurdale area; structural control of the geothermal system; principal structures and trends; depths and thermal gradients of four deep wells; structural geology of reservoir rocks in geothermal system; surface alteration; release of hydrogen sulfide at Cove Fort; differences between surface features at Cove FortSulphurdale and other geothermal areas; mineral assemblages and replacement minerals; subsurface mineral occurrences in the northern portion of the Tushar Mountains; heat source speculations.

MOORE, J. N., Capuano, R. M., and Christensen, O. D., 1983, Geochemical indicators of a high-temperature geothermal system (abs.): Journal of Geochemical Exploration, v. 19, p. 347-348.

MOORE, J. N., Samberg, S. M., and Sibbett, B. S., 1979, Geology of the Cove Fort-Sulphurdale KGRA: Earth Science Laboratory/University of Utah Research Institute Report, no. DOE/ET/28392-27, 44 p.

Geologic setting of geothermal area including volcanic stratigraphy and structural deformation; Tertiary mineralization and alteration of area; alteration products; appendices of lithologic logs from three drill holes; bibliographic annotations of Cove Fort KGRA geology; geologic map and cross sections; sulfide distribution in wells.

MORRIS, H. T., 1978, Preliminary geologic map of Delta two degree quadrangle, west-central Utah: U.S. Geological Survey Open-File Report 78-705, scale 1:250,000.

MORRISON-KNUDSON, 1982, Utah state prison geothermal well test: Morrison-Knudson Company, Inc., 55 p.

Surface and subsurface geology of the Crystal Hot Springs area; shallow aquifer and deep artesian geothermal aquifer descriptions; objective and procedures for well testing; data from step drawdown testing, 300 GPM constant rate test, $600 \mathrm{GPM}$ constant rate test, and recovery monitoring; data from five observation wells and two springs; techniques used and reservoir evaluation parameters; well loss from step drawdown testing; calculations for reservoir formation permeability; porosity and compressibility calculations; reservoir limit, wellbore storage, and skin factor calculations; calculations for transmissibility and coefficient of storage; geochemical reservoir assessment; tables showing chemical analyses of Utah State Prison well waters; table showing ranges in composition of thermal and nonthermal waters; calculated geothermometer temperatures; conclusions and recommendations.

MOWER, R. W., 1978, Hydrology of the Beaver Valley area, Beaver County, Utah, with emphasis on ground water: Utah Department of Natural Resources Technical Publication 63, $90 \mathrm{p}$.

MOWER, R. W., and Cordova, R. M., 1973, Ground water in the Milford area, Utah, in Geology of the Milford area: Utah Geological Association Publication 3, p. 63-71.

MOWER, R. W., and Cordova, R. M., 1974, Water resources of the Milford area, Utah, with emphasis on ground water: Utah Department of Natural Resources, Division of Water Rights, Technical Publication 43, $106 \mathrm{p}$.

MUDGETT, C. D., 1964, Regional gravity survey of parts of Beaver and Millard Counties, Utah: Salt Lake City, Utah, University of Utah, unpublished Masters thesis, $19 \mathrm{p}$.

MUFFLER, L. J. P., 1976, Tectonic and hydrologic control of the nature and distribution of geothermal resources: United Nations symposium on the development and use of geothermal resources, 2d, San Francisco, California, 1975, Proceedings, v. 1, p. 499-508.

MUNDORFF, J. C., 1970, Major thermal springs of Utah: Utah Geological and Mineral Survey Water Resources Bulletin 13,60 p.

MURPHY, Mary, and Entingh, D. J., 1981, Geothermal electric power plant status: Geothermal Resources Council, Transactions, v. 5, p. 607-610.

MURPHY, P. J., 1978, Environmental assessment of proposed shallow temperature gradient holes, northern Utah sites, 1978: Utah Geological and Mineral Survey Open-File Report 26, 17 p.

MURPHY, P. J., 1981, The geologic and hydrogeologic setting of Crystal Hot Springs, a Wasatch Front geothermal system: Geothermal Resources Council, Transactions, v. 5, p. 553-556.

Location of Crystal Hot Springs; flow rates, spring temperatures, and measurements of dissolved solids; regional geology of the Wasatch Front and local horstgraben lineaments; petrology, structural geology, and Tertiary volcanic history of Crystal Hot Springs area; relation of thermal springs to range front faults; three dimensional geometry of Crystal Hot Springs; migration paths of meteoric/thermal waters; depth of major production zone in well USP/TH-1. 
MURPHY, P. J., and Gwynn, J. W., 1979a, Geothermal investigations at Crystal Hot Springs, Salt Lake County, Utah: Utah Geological and Mineral Survey Report of Investigation, no. 139, 91 p.

Regional geologic and structural setting of Crystal Hot Springs area; structure and stratigraphy of Traverse Mountains; descriptions of the hot springs; shallow ground temperature survey; water chemistry; lineaments in the East Traverse Range; magnetic and gravity survey; drill hole data from six geothermal gradient holes; recharge and heat source of geothermal system; appendices of drill hole lithologic logs and temperature gradients.

MURPHY, P. J., and Gwynn, J. W., 1979b, Geothermal investigations at selected thermal systems of the northern Wasatch Front, Weber and Box Elder Counties, Utah: Utah Geological and Mineral Survey Report of Investigation, no. $141,50 \mathrm{p}$.

Regional structural setting of the Wasatch Front of north-central Utah; Utah Hot Springs-description, water chemistry, geologic structure of Pleasant View salient, and one thermal gradient hole; Crystal (Madsen) Hot Springs-description, water chemistry, geology, structure, one thermal gradient hole, and structural controls of source water; Belmont (Udy) Hot Springs-description, water chemistry, geologic and structural setting of West Hills, Wasatch Range, and Malad River Valley graben, shallow ground temperature survey, two thermal gradient holes, and near-surface hydrogeologic system; Little Mountain-south geothermal area-description, hydrogeology, water chemistry, and one thermal gradient hole; heat source for northern Wasatch Front geothermal systems.

MURPHY, P. J., and Gwynn, J. W., 1979c, Geothermal investigation of the Warm Springs fault geothermal system, Salt Lake County, Utah: Utah Geological and Mineral Survey Report of Investigation, no. 140, 33 p.

Warm Springs fault geothermal area and associated springs located along the fault; geology and structure of the Salt Lake salient; shallow ground temperature survey; temperature gradient holes with lithologic logs; water chemistry of springs; preliminary results of gravity survey; heat source of geothermal system.

NASH, W. P., 1976, Petrology of Quaternary volcanics of the Roosevelt KGRA, and adjoining area, Utah: University of Utah, Publications Board Report 261 549/OST, 99 p.

General geologic setting; three sequences of local rhyolitic rocks and their petrographic descriptions; stratigraphy of Cenozoic volcanic rocks; graph showing chemical analyses of Mineral Range volcanic rocks and glasses; graphs showing analyses of bulk rock, glass, and feldspar in samples of local Quaternary rhyolites; tables showing results of microprobe analyses of glass from the Mineral Mountains; tables showing average microprobe analyses of biotite, amphibole, $\mathrm{Fe}-\mathrm{Ti}$ oxides, allanite, and sphene; magmatic temperature estimates; magmatic water fugacity calculations; magmatic density and viscosity calculations; appendix showing all chemical data from wet rock and microprobe analysis.

NASH, W. P., 1981, Topical report: geologic map of the south Twin Peak-Cove Creek area, west-central Utah: Earth Science Laboratory/University of Utah Research Institute Report, no. DOE/ID/12079-38, 5 p., scale $1: 24,000$.

NASH, W. P., and Crecraft, H. R., 1982, Evolution of the Quaternary magmatic system, Mineral Mountains, Utah; interpretations from chemical and experimental modeling: Earth Science Laboratory/University of Utah Research Institute Report, no. DOE/ID/12079-74, 50 p.

NASH, W. P., Crecraft, H. R., and Evans, S. H., Jr., 1980, Volcanism of the Black Rock Desert and Twin Peaks areas, west-central Utah, in Nielson, D. L., ed., Geothermal systems in central Utah: Geothermal Resources Council Annual Meeting, Salt Lake City, Utah, Guidebook to Field Trip, no. 7, p. 36-43.

Bimodal Cenozoic basalt and rhyolite occurrences in the Basin and Range; structural geology of the Black Rock Desert; petrology of basalts and rhyolites; table showing ages of Black Rock Desert volcanic rocks; volcanic stratigraphy; surface indications of geothermal activity; table showing chemical analyses of Black Rock Desert lavas; geologic map of Twin Peaks; volcanic history and petrography of Twin Peaks; table showing K-Ar ages of Twin Peaks lavas; table showing chemical analyses and modes of representative Twin Peaks rhyolites; structure of Twin Peaks area; rhyolite petrogenesis; heat flow measurements.

NASH, W. P., and Evans, S. H., Jr., 1978, Fluid dynamic properties of rhyolitic magmas, Mineral Mountains, Utah; Part I: volatile content and flow characteristics; Part II: physical properties: University of Utah, Department of Geology and Geophysics Final Report, v. 77-13, 47 p.

NASH, W. P., and Hausel, W. D., 1975, Mid- and lateCenozoic volcanism in southwestern Utah (abs.): Geological Society of America Abstracts with Programs, v. 7 , no. 7 , p. 1210-1211.

NASH, W. P., Turley, C., Petersen, J., and Brown, F. H., 1978, Volcanism and the regional assessment of geothermal potential in west-central Utah: Geothermal Resources Council, Transactions, v. 2, sec. 2, p. 475-477.

Geologic setting of west-central Utah; description of indigenous basalts and rhyolites; ages of volcanism; graph of age of rhyolitic centers less than eight million years old versus latitude; table showing chemical analyses of silicic lavas; criteria for exploration of geothermal resources; Roosevelt Hot Springs and Black Rock Desert as examples of areas with good exploration potential. 
NATHENSON, Manuel, Guffanti, M., Sass, J. H., and Munroe, R. J., 1983, Regional heat flow and temperature gradients, in Reed, M. J., ed., Assessment of lowtemperature geothermal resources of the United States-1982: U. S. Geological Survey Circular 892, p. 9-15.

Distribution of heat flow and temperature gradients in the United States; method for estimating deep subsurface temperatures; assessment of low-temperature geothermal resources - mentions Basin and Range region; observations on uniformity of thermal conductivity on regional scale; maps of heat flow and temperature gradient; tables of representative values of thermal conductivities.

NATHENSON, Manuel, and Muffler, L. J. P., 1975, Geothermal resources in hydrothermal convection systems and conduction-dominated areas, in White, D. E., and Williams, D. L., eds., Assessment of geothermal resources of the United States-1975: U.S. Geological Survey Circular 726, p. 104-121.

Resource and reserve estimates of heat in hydrothermal convection systems and conduction-dominated areas in the western United States; analysis of recoverability, utilization efficiency, and economic constraints; calculations of recoverable electrical energy and efficiency of converting thermal energy to electrical energy; two methods for extraction of energy from liquid-filled rock; identification of convection systems and stored heat potential; table of estimated electrical energy potential of high-temperature convection systems including Cove Fort-Sulphurdale and Roosevelt Hot Springs; table of stored heat in intermediate-temperature hydrothermal convection systems including Monroe Hot Springs.

NEHRING, N. L., and Mariner, R. H., 1979, Sulfate-water isotopic equilibrium temperatures for thermal springs and wells of the Great Basin: Geothermal Resources Council, Transactions, v. 3, p. 485-488.

NEHRING, N. L., Mariner, R. H., White, L. D., Heubener, M. A., Roberts, E. D., Harmon, K., Bowen, P. S., and Tanner, L. R., 1979, Sulfate geothermometry of thermal waters in the western United States: U.S. Geological Survey Open-File Report 79-1135, 11 p.

NELSON, M. G., and Bromfield, C. S., 1979, Annotated geologic bibliography for the Richfield $1 \times 2$ degree quadrangle, Utah: U.S. Geological Survey Open-File Report 79-1699, 214 p.

NEWMAN, G. A., 1983, Detection of conductive bodies in a layered earth using the magnetotelluric method: application to silicic magma bodies: Salt Lake City, Utah, University of Utah, unpublished Masters thesis, $50 \mathrm{p}$.

NEWMAN, G. A., Wannamaker, P. E., and Hohmann, G. W., 1983, Detection of conductive bodies in a layered earth using the magnetotelluric method: application to silicic magma bodies: Earth Science Laboratory/Uni- versity of Utah Research Institute Report, no. DOE/ID/12079-96, $51 \mathrm{p}$.

NICHOLS, W. D., 1979, Simulation analysis of the unconfined aquifer, Raft River geothermal area, Idaho-Utah: U.S. Geological Survey Water-Supply Paper 2060, 46 p.

Purpose and scope of study; location and geography of study area; previous investigations; geometry and hydraulic properties of shallow ground-water; table showing summary of aquifer transmissivity, hydraulic conductivity, and specific yield tests; geometry and water level measurements of the water table from 1952 to 1976; table showing water pumpage, in acre feet, for 1952 through 1965 and table showing estimated pumpage, in acre feet, for 1966 through 1974; simulation of the shallow ground-water system; assumptions made in the model; two stages of model development and calibration; table showing steady state boundary recharge rates computed by simulation model; map showing distribution of long-term average steady-state recharge and discharge, in acre feet per year, based on 1952 water levels; map showing transmissivity of the 1952 unconfined aquifer; map showing yield of the unconfined aquifer; table showing average annual pumping rates for 1952 through 1965 used in the calibrated simulation model; predicted effects of increased ground-water pumping; conclusions.

NIELSON, D. L., 1978, Radon emanometry as a geothermal exploration technique: theory and an example from Roosevelt Hot Springs KGRA, Utah: Earth Science Laboratory/University of Utah Research Institute Report, no. DOE/ET/28392-18, 31 p.

Use of radon measurements for locating covered faults that intersect the geothermal reservoir; origin and behavior of radon in geothermal systems; radon survey techniques.

NIELSON, D. L., 1979, Program review, geothermal exploration and assessment technology program (including a report of the reservoir engineering group): Earth Science Laboratory/University of Utah Research Institute Report, no. DOE/ET/27002-6, 128 p.

NIELSON, D. L., 1980, Summary of the geology of the Roosevelt Hot Springs geothermal system, Utah, in Nielson, D. L., ed., Geothermal systems in central Utah: Geothermal Resources Council Annual Meeting, Salt Lake City, Utah, Guidebook to Field Trip, no. 7, p. 25-29.

General geology and structure of area; characteristics of the geothermal system; generalized geologic map and cross section.

NIELSON, D. L., Evans, S. H., Jr., and Sibbett, B. S., in press, Magmatic, structural, and hydrothermal evolution of the Mineral Mountains intrusive complex, Utah: Geological Society of America Bulletin. 
NIELSON, D. L., and Moore, J. N., 1979, The exploration significance of low-angle faults in the Roosevelt Hot Springs and Cove Fort-Sulphurdale geothermal systems, Utah: Geothermal Resources Council, Transactions, v. 3, p. 503-506.

Regional geology, tectonic history, and Tertiary volcanism of Cove Fort-Sulphurdale and Roosevelt Hot Springs; petrology and structure of Cove Fort-Sulphurdale; geometry of rock masses and role of low-angle faults in controlling geothermal reservoirs and convective flow; role geologic structures play in masking convective thermal regimes; structure and geometry of Roosevelt Hot Springs; role of faults as fluid conduits in Roosevelt geothermal system.

NIELSON, D. L., Moore, J. N., and Forrest, R. J., 1980, Road log to geothermal systems in central Utah, in Nielson, D. L., ed., Geothermal systems in central Utah: Geothermal Resources Council Annual Meeting, Salt Lake City, Utah, Guidebook to Field Trip, no. 7, p. 44-54.

Road $\log$ for field trip to Monroe-Joseph, Cove FortSulphurdale, and Roosevelt Hot Springs geothermal areas; schedule, mileage, and directions for the field trip; index map for road log to geothermal systems in central Utah; map showing location of calderas in the Cove Fort-Sulphurdale area; geologic map of Roosevelt Hot Springs KGRA showing location of drill holes and field trip stops.

NIELSON, D. L., Sibbett, B. S., and McKinney, D. B., 1979, Geology and structural control of geothermal system at Roosevelt Hot Springs KGRA, Beaver County, Utah (abs.): American Association of Petroleum Geologists Bulletin, v. 63, no. 5, p. 836.

Location of the Roosevelt Hot Springs KGRA; regional geology; regional metamorphic and plutonic histories; structure of area; characteristics of the geothermal system including heat source and reservoir description.

NIELSON, D. L., Sibbett, B. S., McKinney, D. B., Hulen, J. B., Moore, J. N., and Samberg, S. M., 1978, Geology of Roosevelt Hot Springs KGRA, Beaver County, Utah: Earth Science Laboratory/University of Utah Research Institute Report, no. DOE/ET/28392-19, 120 p.

Regional geologic setting; lithologies and modal analyses of Precambrian rocks and Tertiary intrusives in the Mineral Mountains; subsurface information obtained from wells; structure of the geothermal system; appendices of logs showing lithology, alteration, and mineralization from several wells.

NIMMONS, J. T., Kotz, S., and Metzger, J., 1979, Stateby-state analysis of public utility laws affecting geothermal direct heat applications: Energy Studies Project, The Earl Warren Legal Institute, University of California, Berkeley, California, $51 \mathrm{p}$.

NOBLE, D. C., and McKee, E. H., 1972, Description and $\mathrm{K}-\mathrm{Ar}$ ages of volcanic units of the Caliente volcanic field, Lincoln County, Nevada and Washington County, Utah: Isochron/West, no. 5, p. 17-24.

O'CONNELL, M. F., and Kaufmann, R. F., 1976, Radioactivity associated with geothermal waters in the western United States: U.S. Environmental Protection Agency, Technical Note ORP/LV-75-8A, 25 p.

OLSON, T. L., 1976, Earthquake surveys of the Roosevelt Hot Springs and the Cove Fort areas, Utah: Salt Lake City, Utah, University of Utah, unpublished Masters thesis, $80 \mathrm{p}$.

Purpose of study; historical sketch of similar studies; location of survey; geology and Tertiary volcanic history of the Milford-Roosevelt and Cove Fort-Sulphurdale areas; previous gravity surveys; historical seismicity; data collection and reduction; tables showing velocity models; epicenter map for Roosevelt Hot Springs and Cove Fort; earthquake occurrence and clustering for the 1974-1975 surveys; magnitudes and b-values for detected earthquakes; fault plane solutions; examination of P-wave travel time residuals; stochastic modeling; conclusions.

OLSON, T. L., Sill, W. R., and Smith, R. B., 1976, Integrated geophysics, Roosevelt Hot Springs (abs.): Geophysics, v. 41 , no. 2 , p. 368.

Geophysical studies and methods of data interpretation from Roosevelt Hot Springs; suggested exploration sequences for Roosevelt-type resources.

OLSON, T. L., and Smith, R. B., 1976, Earthquake surveys of the Roosevelt Hot Springs and the Cove Fort areas, Utah: University of Utah, Department of Geology and Geophysics Report, v. 4, 83 p.

Purpose of survey; general geology and velocity model; comparison of epicenters and earthquake activity at Cove Fort and Roosevelt; fault plane solutions determined for earthquake activity; examines P-wave travel time residuals and $\mathrm{S}$-wave attenuation; stochastic modeling of earthquake occurrence; appendix of location, time, depth, and magnitude of earthquake activity during survey period.

OLSON, T. L., and Smith, R. B., 1977, Pleistocene volcanic ash deposits in Utah: Utah Geology, v. 4, no. 1, p. 35-42.

OSMOND, J. C., 1958, Tectonic history of the Basin and Range Province in Utah and Nevada (abs.): Mining Engineering, v. 10, no. 11 , p. 1132 and 1134 ; also, 1960 , Mining Engineering, v. 12, no. 3, p. 251-265; also, 1960, Geoscience Abstracts, v. 2, no. 6, p. 14 (2-1394).

OTTE, Carel, 1980, Overview of geothermal energy developments (abs.): American Association of Petroleum Geologists Bulletin, v. 64, no. 5, p. 761.

OVERTON, H. L., and Hanold, R. J., 1977, Geothermal reservoir categorization and stimulation study: National Technical Information Service Report LA-6889-MS, $62 \mathrm{p}$. 
PACK, F. J., 1927, Structure of thermal springs on the Wasatch fault: American Journal of Science, v. 214 (5s, 14), p. 409-418; also, (abs.) Geological Society of America Bulletin, v. 38 , no. 1, p. 161; also, (abs.), PanAmerican Geology 47, p. 155.

PACK, F. J., and Carrington, A. C., 1921, Geologic and economic resources, Weber County, Utah: Utah University Bulletin, v. 11, no. 19,61 p.

PAMPAYAN, E. H., 1984, Geologic map of the $30 \times 60$ minute Lynndyl quadrangle, Tooele, Juab, Utah, and Millard Counties, Utah: U.S. Geological Survey OpenFile Report 84-660, scale 1:100,000.

PARRY, W. T., 1978, Hydrothermal alteration at the Roosevelt Hot Springs thermal area, Utah: Part I. Mineralogy of the clay fraction from cuttings, Thermal Power Co. well Utah State 14-2; Part II. Chemical composition rocks, Thermal Power Co. well Utah State 14-2: University of Utah Department of Geology and Geophysics Technical Report, no. IDO/78-1701-a.1.1.2, unpaginated.

Part I: Use of X-ray diffraction techniques to determine mineralogy from drill cuttings; sample selection and preparation; clay mineralogy; interpretation of hydrothermal alteration. Part II: Chemical composition of rocks in well 14-2; use of X-ray fluorescence techniques to determine chemical composition of rocks; sample selection and preparation; rock composition; tables of chemical analyses of rocks.

PARRY, W. T., Ballantyne, J. M., and, Bryant, N. L., 1980 , Hydrothermal alteration enthalpy and heat flow in the Roosevelt Hot Springs thermal area, Utah: Journal of Geophysical Research, v. 85, no. B5, p. 2559-2566.

Evaluates alteration enthalpy for a variety of alteration reactions; analyses of alteration minerals; probable chemical reactions and enthalpy produced during reactions; methods for identification of alteration minerals; calculation of alteration enthalpy; heat flow estimates of chemical reactions; temperature-depth profile.

PARRY, W. T., Ballantyne, J. M., Bryant, N. L., and Dedolph, R. E., 1980, Geochemistry of hydrothermal alteration at the Roosevelt Hot Springs thermal area, Utah: Geochimica et cosmochimica acta, v. 44 , no. 1 , p. 95-102.

Describes spring deposits and surface alteration; subsurface alteration in three shallow drill holes; water chemistry; alteration mineral assemblages; modeling of mass transfer from chemical reactions between microcline and thermal waters; table of chemical analyses and modal mineralogical compositions of rocks from Roosevelt Hot Springs; table of major chemical constituents in selected thermal water; activity diagram for minerals occurring in altered rocks.

PARRY, W. T., Benson, N. L., and Miller, C. D., 1976, Geochemistry and hydrothermal alteration at selected Utah hot springs: University of Utah, Department of
Geology and Geophysics Final Report, v. 3, NSF Grant GI-43741, 131 p.; also, National Technical Information Service Report 264-415/1, 141 p.

Stratigraphy and structural history of Utah; map showing Na-K-Ca temperatures of Utah warm springs; graph showing variation in dissolved anions in well water with distance along the water flow path; mixing models for Abraham Hot Springs and Red Hill Hot Springs; geology, surficial alteration, and spring deposits in the Roosevelt area; tables showing chemical analyses of outcrop and core samples from Roosevelt Hot Springs; alteration assemblages with depth at Roosevelt; activity diagrams showing stability of alteration minerals in the presence of quartz and unit activity of water at 100 and 200 degrees C; graph of mercury content of soils from Roosevelt; gamma ray spectrometric measurements of various rock types from Milford; location and general geology of the Monroe KGRA; alteration map of the Monroe area; $\mathbf{R}$ and $\mathbf{Q}$ mode cluster analysis from Monroe; Red Hill and Monroe spring water geochemistry.

PARRY, W. T., Bryant, N. L., Dedolph, R. E., Ballantyne, J. M., Ballantyne, G. H., Rohrs, D. T., and Mason J. L., 1978, Hydrothermal alteration at the Roosevelt Hot Springs thermal area, Utah: Universtiy of Utah, Department of Geology and Geophysics Final Report, no. IDO/78-1701.a.1.1, 29 p.

Chemical analyses and mineralogy of outcrops; analysis of three shallow cores for shallow subsurface alteration and of three deep cores for deep subsurface alteration; model of hot water-rock interaction.

PARRY, W. T., and Cleary, M., 1978, Na-K-Ca and silica temperature estimates for Utah spring and well waters: University of Utah, Department of Geology and Geophysics Final Report, v. 78-1, 51 p.

Use of Na-K-Ca geothermometers to estimate subsurface temperatures in geothermal areas; anomalous hightemperatures of Utah thermal spring waters; objectives of investigation; data selection and compilation; map showing distribution of anomalous $\mathrm{Na}-\mathrm{K}-\mathrm{Ca}$ and silica temperatures in Utah; maps showing geology and $\mathrm{Na}$ $\mathrm{K}-\mathrm{Ca}$ and silica temperatures of spring and well waters from Dugway Valley, Goshen Valley, Pavant Valley, and Skull Valley; tables showing major constituents and chemical temperatures of spring and well water from Dugway Valley, Goshen Valley, Pavant Valley, and Skull Valley; mixing models for Pavant Valley, Crater Hot Springs, Goshen Valley, Skull Valley, and Warm Springs; methods of water collection and analysis; table of WATEQ mineral saturation values; table of mineralogy and pore water chemistry of Jordan Valley and Great Salt Lake sediment samples; conclusions.

PARRY, W. T., Nash, W. P., Bowman, J. R., Ward, S. H., Whelan, J. A., Bryant, N. L., Deodolph, R. E., Evans, S. H., Jr., and Bowers, D., 1977, Part I - Geology and geochemistry of the Roosevelt Hot Springs - a summary: 
University of Utah, Department of Geology and Geophysics Report, no. 77-2, 12 p.

Geology of Roosevelt Hot Springs; composition of spring deposits and alteration products; chemical analyses of surface and deep thermal waters; tables of water and chemical analyses of altered rocks from Roosevelt Hot Springs; maps of Tertiary and Quaternary volcanics.

PARRY, W. T., Nash, W. P., and Ward, S. H., 1977, Part III - Roosevelt Hot Springs area field trip: Earth Science Laboratory/University of Utah Research Institute Report, no. 77-2, $11 \mathrm{p}$.

Road log for two day field trip; stops include Pavant Butte, Ice Springs lava flow, White Mountain, North and South Twin Peaks, Opal Mound, and Phillips geothermal wells at Roosevelt Hot Springs.

PE, Win, 1980, Gravity survey of the Escalante Desert and vicinity, in Iron and Washington Counties, Utah: Salt Lake City, Utah, University of Utah, unpublished Masters thesis, $151 \mathrm{p}$.

PE, Win, and Cook, K. L., 1980a, Gravity survey of the Escalante Desert and vicinity, in Iron and Washington Counties, Utah: Earth Science Laboratory/University of Utah Research Institute Report, no. DOE/ID/12079-14, $169 \mathrm{p}$.

PE, Win, and Cook, K. L., 1980b, Principal facts for gravity stations: Escalante Desert and vicinity, Iron and Washington Counties, Utah: Earth Science Laboratory/University of Utah Research Institute Open-File Report, no. UT/ED/GG-1, 3 p.

PEALE, A. C., 1872, Report on minerals, rocks and thermal springs: U.S. Geologic and Geographic Survey Territory (Hayden) 5th Annual Report, p.165-168.

PEALE, A. C., 1886, List and analyses of the mineral springs of the United States (a preliminary study): U.S. Geological Survey Bulletin 32, p. 185-187.

PENTA, Francesco, 1960, Natural vapors ("endogene forces"), state of research and considerations (discussion): Bulletin of Volcanology, v. 23, ser. 2, p. 219-235.

PERA, E. M., 1978a, Leasable mineral and waterpower land classification map of the Richfield 1X2 degree quadrangle, Utah: U.S. Geological Survey Miscellaneous Investigation Series Map I-1104, scale 1:250,000.

PERA, E. M., 1978b, Leasable mineral and waterpower land classification map of the Salt Lake City $1 \mathrm{X} 2$ degree quadrangle, Utah and Wyoming: U.S. Geological Survey Miscellaneous Investigation Series Map I-1105, scale $1: 250,000$.

PERA, E. M., Smedley, J. E., and Curtis, N. L., 1977, Leasable mineral and waterpower land classification map of the Tooele quadrangle, Utah: U.S. Geological Survey Open-File Report 77-602, scale 1:250,000.

PERA, E. M., Smedley, J. E., and Flot, T. R., 1978, Leasable mineral and waterpower land classification map of the Brigham City quadrangle, Utah, Idaho: U.S. Geological Survey Open-file Report 78-337, scale 1:250,000.

PERA, E. M., Smedley, J. E., Simpson, L. A., and Lutz, G. A., 1976, Leasable mineral and waterpower land classification map of the Cedar City quadrangle, Utah: U.S. Geological Survey Open-File Report 76-828, scale 1:250,000.

PETERSEN, C. A., 1973, Roosevelt and Thermal Hot Springs, Beaver County, Utah, in Geology of the Milford area: Utah Geological Association Publication 3, p. 73-74.

General geology and temperature estimates for Roosevelt and Thermo springs areas.

PETERSEN, C. A., 1975a, Geology and geothermal potential of the Roosevelt Hot Springs area, Beaver County, Utah: Salt Lake City, Utah, University of Utah, unpublished Masters thesis, $50 \mathrm{p}$.

Purpose of report; location and accessibility of study area; field and laboratory methods; geography of the Roosevelt Hot Springs area; previous investigations; stratigraphy, lithology, igneous and volcanic history, and Quaternary geology of area; structural geology; description of hot springs, hot spring deposits, and wells; tables showing mineral percentages in rock samples; existing surface characteristics of Roosevelt Hot Springs resort area, Negro Mag Wash, and Opal area; drill holes in area; water chemistry of Roosevelt Hot Springs; geochemical thermometers; speculation of possibility of a commercial geothermal system in the Roosevelt area.

PETERSEN, C. A., 1975b, Geology of the Roosevelt Hot Springs area, Beaver County, Utah: Utah Geological and Mineral Survey Utah Geology, v. 2, no. 2, p. 109-116.

See Petersen (1975a).

PETERSON, D. L., 1972, Complete Bouguer gravity anomaly map of parts of Beaver, Iron, and Millard Counties, southwestern Utah: U.S. Geological Survey Open-File Report 72-297, scale 1:250,000.

PETERSON, D. L., 1974, Principal facts for gravity stations, in parts of Beaver, Iron, and Millard Counties: U.S. Geological Survey Open-File Report 74-298, 9 p.

PETERSON, J. B., 1979, Petrologic study of the Fumarole Butte volcanic complex: Salt Lake City, Utah, University of Utah, unpublished Masters thesis, $63 \mathrm{p}$.

Location of Fumarole Butte volcanic complex; previous studies in the area; regional and local geology; geophysical investigations and results; temperature ranges for waters from adjacent Crater Springs area; geochronologic data; petrographic descriptions; mineralogy and electron microprobe analysis of minerals; chemical analysis and CIPW norms of volcanic rocks and residual glasses; trace element analysis; geothermometry and geobarometry of samples; petrogenesis of area; geothermal potential. 
PETERSON, J. B., Turley, C. H., Nash, W. P., and Brown, F. H., 1978, Late Cenozoic basalt-rhyolite volcanism in west-central Utah (abs.): Geological Society of America Abstracts with Programs, v. 10, no. 5, p. 236.

PETERSON, J. B., and Nash, W. P., 1980, Studies in late Cenozoic volcanism in west-central Utah; Part 2, Geology and petrology of the Fumarole Butte volcanic complex, Utah: Utah Geological and Mineral Survey Special Studies 52, p. 34-58.

See Peterson (1979).

PETRICK, W. E., 1976, Test electromagnetic soundings, Roosevelt Hot Springs KGRA: University of Utah, Department of Geology and Geophysics Technical Report, no. TR-74-1, NSF/RA-760367, 21 p.

Location and geology of Roosevelt Hot Springs; location of a vertical magnetic dipole survey and arrangement of transmitters and receivers; conclusions of survey.

PHELPS, P. L., Ermak, D. L., Anspaugh, L. R., Jackson, C. D., and Miller, L. A., 1978, Preliminary environmental assessments of known geothermal resource areas in the United States: Geothermal Resources Council, Transactions, v. 2, p. 523-526.

PHILLIPS PETROLEUM COMPANY, 1979, Cove-Fort microearthquake survey-senturian telmo survey: Earth Science Laboratory/University of Utah Research Institute Open-File Report, no. UT/CFS/STS, unpaginated.

Location and extent of Black Point anomaly; faults mapped via a ground motion survey; events detected by three Cove Creek microearthquake arrays; clusters defined; structural interpretation of a magnetic low; map showing array stations and event epicenters; signature records of select events; graphs showing seismic events versus calendar day; graphs showing seismic events versus azimuth.

PHILLIPS PETROLEUM COMPANY, 1980, Plan of operation for Roosevelt Hot Springs geothermal project 20 MW (net) power plant Beaver County, Utah: Phillips Petroleum Company Geothermal Operations, P. O. Box 239, Salt Lake City, Utah 84110, 122 p.

Proposals for development of the Roosevelt geothermal resource; injection operation proposals; power plant construction proposal.

PHOENIX GEOPHYSICS, INCORPORATED, 1976, Report on the reconnaissance resistivity survey on the Cove Fort Prospect, Beaver and Millard Counties, Utah, for Union Oil Company of California: Earth Science Laboratory/University of Utah Research Institute Open-File Report, no. UT/CFS/UOC-1.4, 7 p.

Map of survey area with locations of survey lines and Schlumberger soundings; resistivity anomalies.

POLLARD, D. D., 1978, Pressurized fractures in hot rock: U.S. Geological Survey Professional Paper 1100, 199 p.

POTTER, R. W., II, Shaw, D. R., and Haas, J. L., Jr., 1975, Annotated bibliography of studies on the density and other volumetric properties for major components in geothermal waters 1928-1974: U.S. Geological Survey Bulletin 1417, $78 \mathrm{P}$.

PRICE, Don, 1980, Map showing general chemical quality of surface water in the Richfield quadrangle, Utah: U.S. Geological Survey Miscellaneous Investigations Series Map I-1234, scale 1:250,000.

PRICE, Don, 1981, Map showing general chemical quality of ground water in the Richfield quadrangle, Utah: U.S. Geological Survey Miscellaneous Investigations Series Map 1-1374, scale 1:250,000.

PUSHKAR, Paul, and Condie, K. C., 1973, Origin of the Quaternary basalt from the Black Rock Desert region, Utah - strontium isotopic evidence: Geological Society of America Bulletin, v. 84, no. 3, p. 1053-1057.

RASBAND, J. L., 1981, Summary of Utah Power and Light Company geothermal activities: Fifth Annual Stanford Geothermal Conference and Workshop, Proceedings, p. 3.3-3.7.

RASBAND, J. L., 1982, Wellhead geothermal development activities: Roosevelt Hot Springs geothermal reservoir: Sixth Annual Stanford Geothermal Conference and Workshop, Proceedings, p. 2.1-2.2.

Research conducted by Utah Power and Light Company to determine the feasibility of development of wellhead generating unit at Roosevelt Hot Springs.

RASBAND, J. L., 1983, Roosevelt Hot Springs, Utah: geothermal power developments: Transactions of the American Nuclear Society, v. 45, p. 10-11.

Terms of agreement between Utah Power and Light Company and Phillips Petroleum Company for sale and purchase of Roosevelt Hot Springs geothermal fluids; steam sales agreement between Utah Power and Light and the ATO group; design and construction plans for a 20-MW geothermal generating unit; plans to develop a wellhead generating system to handle both steam and water well fluids; current status of engineering and construction of Milford No. 1 generating unit.

REED, M. J., 1977, Geochemical comparison of deep geothermal waters in North America (abs.): Geological Society of America Abstracts with Programs, v. 9, no. 7, p. 1138.

REED, M. J., Mariner, R. H., Brook, C. A., and Sorey, M. L., 1983, Selected data for low-temperature (less than 90 degrees C) geothermal systems in the United States; reference data for U.S. Geological Survey Circular 892: U.S. Geological Survey Open-File Report 83-250, 132 p.

Compilation of data used in 1982 study of lowtemperature geothermal resources of the United States; methods used to obtain data; geothermal reservoir conditions and energies calculated for each system; table of location, temperature, flow rate, and chemical composition for low-temperature sites, over 230 Utah sites; table showing temperature range, calculated energies, 
and geologic provinces for the United States lowtemperature systems, 100 Utah sites; table showing range of values for reservoir parameters and the mean transmissivity for low-temperature geothermal systems, 19 Utah sites.

REED, M. J., and Sorey, M. L., 1981, Low-temperature geothermal resource assessment of the United States - a progress report: Geothermal Resources Council Bulletin, v. 10 , no. 6 , p. 11-14.

REIMER, G. M., 1979, Reconnaissance survey of helium in soil gas in the eastern half of Richfield 1X2 degree quadrangle, Utah: U.S. Geological Survey Open-File Report 79-1686, 8 p.

REIMER, G. M., Roberts, A. A., and Denton, E. H., 1976, The use of helium detection to locate energy resources (abs.): Geological Society of America Abstracts with Programs, v. 8, no. 6, p. 1063-1064.

RENNER, J. L., and Galyardt, G. L., 1976, Hydrothermal convection systems in Utah, in Renner and others, Selected geothermal resources data: hydrothermal convection systems in the states of Alaska, Arizona, California, Colorado, Hawaii, Idaho, Montana, Nevada, New Mexico, Oregon, Utah, Washington, and Wyoming: National Technical Information Service Report, no. PB 250-377, p. $324-334$.

RENNER, J. L., White, D. E., and Williams, D. L., 1975, Hydrothermal convection systems, in White, D. E., and Williams, D. L., eds., Assessment of geothermal resources of the United States-1975: U.S. Geological Survey Circular 726, p. 5-57.

Definition of convective systems and subdivision into vapor or hot water dominated systems; origin and fundamental characteristics of both; evolutionary model of hot water systems into vapor dominated systems; identification and classification of several known geothermal systems of the two types; use of silica and $\mathrm{Na}-\mathrm{K}-\mathrm{Ca}$ ratios as chemical geothermometers; tables of hot water convection systems in the western United States with indicated subsurface temperatures above 150 degrees $\mathrm{C}$ (one area in Utah) and with subsurface temperatures from 90 degrees to 150 degrees $C$ (six areas in Utah).

RICHARDSON, G. B., 1906, Underground water in the valleys of Utah Lake and Jordan River, Utah: U.S. Geological Survey Water-Supply Paper 157, 81 p.

RICHARDSON, G. B., 1907, Underground water in Sanpete and central Sevier Valleys, Utah: U.S. Geological Survey Water-Supply Paper 199, 63 p.

RITZMA, H. R., 1972, Six Utah "hingeline" wells, in Baer, J. L., and Callaghan, E., eds., Plateau-Basin and Range transition zone, central Utah: Utah Geological Association, Publication 2, p. 75-80.

ROBINSON, R., and Iyer, H. M., 1979, Evidence from teleseismic P-wave observations for a low velocity body under the Roosevelt Hot Springs Geothermal Area,
Utah: Geothermal Resources Council, Transactions, v. 3, p. 585-586.

Velocity structure investigations of the crust and upper mantle near Roosevelt Hot Springs using 15 seismographs on a $30 \times 30 \mathrm{~km}$ array; teleseismic events recorded and travel-time residual calculations; patterns of resulting travel-time residuals and their interpretations; region of low velocity under Mineral Mountains; evidence for anomalous region at shallow depths under central Mineral Mountains.

ROBINSON, R., and Iyer, H. M., 1981, Delineation of a low-velocity body under the Roosevelt Hot Springs geothermal area, Utah, using teleseismic P-wave data: Geophysics, v. 46, no. 10, p. 1456-1466.

Examines deep structure of Roosevelt area using teleseismic P-wave traveltime variations; geologic setting; analysis and inversion of data; resulting model of layers in crust and deeper mantle in Roosevelt vicinity; tables of residual times and teleseismic events; contour maps of velocity changes within different layers of model.

RODRIGUEZ, E. L., 1960, Economic geology of the sulfur deposits at Sulphurdale, Utah: Salt Lake City, Utah, University of Utah, unpublished Masters thesis, $74 \mathrm{p}$.

General geology, stratigraphy, and structure of Sulphurdale area; occurrence and classification of sulfur deposits; description and paragenesis of ore and gangue minerals genetically related to sulfur deposits; ore reserve calculations; mining methods, costs, and market potential for Sulphurdale mines; map of principal sulfur deposits.

ROGERS, H. I., 1978, Financing and construction of a commercial geothermal power plant in Utah, in Commercialization of Geothermal Resources: Geothermal Resources Council Conference on Commercialization of Geothermal Resources, San Diego, California, p. $39-42$.

ROHRS, D. T., 1980, A light stable isotope study of the Roosevelt Hot Springs thermal area, southwestern Utah: Salt Lake City, Utah, University of Utah, unpublished Masters thesis, $94 \mathrm{p}$.

Previous work; general geology, structure, and intrusive and extrusive history of area; mineral deposits and alteration; table showing major chemical constituents of waters from Roosevelt Hot Springs; sample selection and preparation; analytical procedures including extraction techniques and mass spectrometry; table showing isotopic analyses of waters, silicates, and carbonates from the Roosevelt area; origin of thermal waters; water/rock atomic oxygen ratio calculations; extent of isotopic change; isotopic composition of $\mathrm{K}$-mica clays and calcite; carbon isotopic composition of calcite; conclusions; suggestions for future isotopic studies.

ROHRS, D. T., and Bowman, J. R., 1980, A light stable isotope study of the Roosevelt Hot Springs thermal area, southwestern Utah: Earth Science Laboratory/Universi- 
ty of Utah Research Institute Report, no. DOE/ET/28392-46, 89 p.

See Rohrs (1980).

ROHRS, D. T., and Parry, W. T., 1978, Hydrothermal alteration at the Roosevelt Hot Springs thermal area, Utah; Thermal Power Co. well Utah State 72-16: University of Utah, Department of Geology and Geophysics Topical Report, no. IDO/ 78-1701.a.1.1.3, 23 p.

Sample collection, preparation, and analytical procedures; lithologic descriptions of samples from drill hole 72-16; alluvium lithology; lithologic descriptions of igneous samples with estimates of mineral composition; changes in hydrothermal alteration with depth; quartz, $\mathrm{K}$-feldspar, plagioclase, sphene, apatite, hornblende, and biotite alteration; veinlet fillings and clay mineralogy.

ROSS, H. P., 1979, Numerical modeling and interpretation of dipole-dipole resistivity and IP profiles Cove FortSulphurdale KGRA, Utah: Earth Science Laboratory/University of Utah Research Institute Report, no. DOE/ET/28392-37, 39 p.

Map showing location of Cove Fort-Sulphurdale KGRA, the adjacent geothermal resource areas, and the divisions of the High Plateaus; general geology and past geophysical surveys; table showing summary of Cove Fort-Sulphurdale resistivity data; methods used to interpret resistivity data and problems encountered; map showing interpreted resistivity section and observed apparent resistivity; comparison of resistivity distribution with geologic data; map of interpreted electrical resistivity (depth interval 0-300 feet and 1500-2000 feet); table showing interpreted electrical resistivities for geologic units at Cove Fort-Sulphurdale; conclusions; appendix showing resistivity data summary for Cove Fort-Sulphurdale.

ROSS, H. P., and Moore, J. N., 1985, Geophysical investigations of the Cove Fort-Sulphurdale geothermal system, Utah: Geophysics, v. 50, no. 11, p. 1732-1745.

Geologic setting of the Cove Fort-Sulphurdale thermal anomaly; local geologic history, petrology, stratigraphy, structure, and mineral and rock alteration; detailed geologic maps of the study area; results of Cove FortSulphurdale and Roosevelt Hot Springs seismic, gravity, magnetic, thermal, and electrical resistivity surveys; four test wells drilled in study area; table showing basic data for four Cove Fort-Sulphurdale test wells; geothermal mud log with drilling rate, rock density, mud temperatures, lithology, $\mathrm{H}_{2} \mathrm{~S}$ and $\mathrm{CO}_{2}$, a dual injection spherically focused $\log$ with linear correlation $\log$, and a compensated neutron-formation density $\log$ with caliper and gamma ray obtained from three wells; discussion of well log interpretations; conclusions of study.

ROSS, H. P., Moore, J. N., and Christensen, O. D., 1982, The Cove Fort-Sulphurdale KGRA, a geologic and geophysical case study: Earth Science Laboratory/Uni- versity of Utah Research Institute Report, no. DOE/ID/12079-64, 47 p.

Integrated summary and current interpretation of geology, geophysics, and geochemistry of study area; general geology includes regional stratigraphy, structure, and hydrology; distribution and chemical characteristics of hydrothermally altered rocks; geophysical studies using seismicity, gravity, magnetics, thermal data, electrical resistivity, and geophysical log interpretations; maps of gravity anomalies, magnetic intensities, geology, and electrical resistivity surveys; geologic cross sections; temperature-depth profiles.

ROSS, H. P., Nielson, D. L., and Glenn, W. E., 1981, Roosevelt Hot Springs, Utah geothermal resource; integrated case study (abs.): American Association of Petroleum Geologists Bulletin, v. 65, no. 5, p. 982.

Location and development of Roosevelt Hot Springs; reservoir parameters including structural controls, host rocks, heat flow, and electrical resistivity; trace element geochemistry; exploration strategies.

ROSS, H. P., Nielson, D. L., and Moore, J. N., 1982, Roosevelt Hot Springs geothermal system, Utah - case study: American Association of Petroleum Geologists Bulletin, v. 66, no. 7, p. 879-902.

Regional and local geology; description of hydrothermal system including fluid chemistry, hydrothermal alteration, and flow tests; use of electrical, thermal, seismic, gravity, and magnetic data for exploration of the geothermal system; retrospective exploration strategy.

ROWAN, L. C., Podwysoki, M. H., and Offield, T. W., 1983, Analysis of lineaments in the Great Basin: relationship to geothermal resources, in The role of heat in the development of energy and mineral resources in the northern Basin and Range Province: Geothermal Resources Council Special Report 13, p. 317-318.

ROWLEY, P. D., 1978, Geologic map of the Thermo 15minute quadrangle, Beaver and Iron Counties, Utah: U.S. Geological Survey, Geological Quadrangle Map GQ-1493, scale 1:62,500.

ROWLEY, P. D., Anderson, J. J., and Williams, P. L., 1975, A summary of Tertiary volcanic stratigraphy of the southwestern High Plateaus and adjacent Great Basin, Utah: U. S. Geological Survey Bulletin 1405-B, 20 p.

ROWLEY, P. D., Cunningham, C. G., and Kaplan, A. M., 1981, Geologic map of the Monroe SE quadrangle, Sevier and Piute Counties, Utah: U.S. Geological Survey Miscellaneous Field Studies Map MF-1331, scale $1: 24,000$.

ROWLEY, P. D., Cunningham, C. G., Steven, T. A., Mehnert, H. H., and Naeser, C. W., 1985, Geologic map of the Antelope Range quadrangle, Sevier and Piute Counties, Utah: Utah Geological and Mineral Survey OpenFile Report, no. 81, 52 p., scale 1:24,000. 
ROWLEY, P. D., and Lipman, P. W., 1975, Geological setting of the Thermo KGRA (known geothermal resource area), Beaver County, Utah (abs.): Geological Society of America Abstracts with Programs, v. 7, no. 7, p. 1254.

General geologic setting including structure, recent volcanic history, and surface alteration.

ROWLEY, P. D., Lipman, P. W., Mehnert, H. H., Lindsey, D. A., and Anderson, J. J., 1978, Blue Ribbon lineament, an east-trending structural zone within the Pioche mineral belt of southwestern Utah and eastern Nevada: U.S. Geological Survey Journal of Research, v. 6, no. 2, p. 175-192.

ROWLEY, P. D., Steven, T. A., Anderson, J. J., and Cunningham, C. G., 1979, Cenozoic stratigraphic and structural framework of southwestern Utah: U.S. Geological Survey Professional Paper 1149, 22 p.

ROWLEY, P. D., Steven, T. A., and Kaplan, A. M., 1981, Geologic map of the Monroe NE quadrangle, Sevier County, Utah: U.S. Geological Survey Miscellaneous Field Studies Map MF-1330, scale 1:24,000.

ROWLEY, P. D., Steven, T. A., and Mehnert, H. H., 1980, Pliocene rhyolite in the Sevier Plateau, Utah (abs.), in Geological Survey research 1979: U.S. Geological Survey Professional Paper 1150, p. 73.

ROWLEY, P. D., Steven, T. A., and Mehnert, H. H., 1981, Origin and structural implications of Pliocene and upper Miocene rhyolite in Kingston Canyon, Piute County, Utah: Geological Society of America Bulletin, v. 92 , no. 8 , p. $590-602$.

ROXLO, K. S., 1980, Uranium geochemistry of the Roosevelt Hot Springs thermal area, Utah: Salt Lake City, Utah, University of Utah, unpublished Masters thesis, $62 \mathrm{p}$.

General geology of study area; table showing trends of magmatic differentiation of the Mineral Mountains pluton; shallow drill hole lithologic logs from three holes; hydrothermal alteration characteristics of area; methods of uranium analysis; uranium occurrence in rocks; table showing fluorimetrically determined uranium values of well lithologies as a function of depth; statistical correlations; water chemistry; temperature and pressure regimes; tables showing uranium concentration in water; estimates of thermodynamic properties of dissolved uranium species and minerals; table showing heat capacities for uranium and other solution species over various temperature ranges; activity of uranium solution species and minerals; coffinite and $\mathrm{Na}$ autunite solubility in the Roosevelt area; zero point of charge and adsorption; conclusions.

RUDISILL, J. M., 1978, Case history: the completion of a shallow, over-pressured geothermal well: Geothermal Resources Council, Transactions, v. 2, sec. 2, p. 587-590.

RUSCETTA, C. A., ed., 1982, Geothermal direct heat program, round up technical conference proceedings, volume II: Bibliography of publications: Earth Science Laboratory/University of Utah Research Institute Report, no. DOE/ID/12079-72, p. 60.

RUSH, F. E., 1977, Subsurface-temperature data for some wells in western Utah: U.S. Geological Survey Open-File Report 77-132, $36 \mathrm{p}$.

RUSH, F. E., 1983, Reconnaissance of the hydrothermal resources of Utah: U.S. Geological Survey Professional Paper 1044-H, p. H1-H49.

Purpose and scope of study; index map of Utah delineating prospective geothermal land; geologic setting of Utah; regional hydrology, heat flow, and relation of thermal waters to hydrogeologic framework; equation for computing conductive heat flow; distribution of thermal waters; table of estimated reservoir temperatures derived from geothermometer formulas; geology of Roosevelt area and thermal spring characteristics; location and geology of Thermo Hot Springs area; maps showing audiomagnetotelluric configuration, temperature at depth, and vegetation distribution for Thermo Hot Springs; location, geology, and estimated heat flow in the Escalante Desert; chemical analyses of thermal waters near Newcastle, Monroe, Joseph, and Crater Hot Springs KGRAs; geothermal potential near Salt Lake City.

RUSH, F. E., Hart, I. M., Whitfield, M. S., Giles, T. F., and D'Epagnier, T. E., 1980, Results of hydraulic tests in wells DOE-1, 2, 3, Salt Valley, Grand County, Utah: U.S. Geological Survey Open-File Report 80-205, 38 p.

SAMBERG, S. M., 1980, Geologic framework of the Monroe-Red Hill geothermal system, Utah, in Nielson, D. L., ed., Geothermal systems in central Utah: Geothermal Resources Council Annual Meeting, Salt Lake City, Utah, Guidebook to Field Trip, no. 7, p. 1-5.

Geologic model of Monroe-Red Hill resource area; volcanic geology; structural setting; description of spring deposits; temperature of thermal waters; table of water analyses.

SAMMEL, E. A., 1979, Occurrence of low-temperature geothermal waters in the United States, in Muffler, L. J. P., ed., Assessment of geothermal resources of the United States-1978: U.S. Geological Survey Circular 790 , p. $86-131$.

Information on low-temperature (less than 90 degrees C) geothermal waters at depths less than $1 \mathrm{~km}$; discusses occurrences in western, central, and eastern United States; defines temperatures of thermal springs; table of areas of low-temperature geothermal water potential (eight areas in Utah); map of the United States showing hydrothermal convection systems, igneous systems, low-temperature geothermal waters, and regional heat flow.

SANDBERG, S. K., 1980, Controlled-source audiomagnetotellurics in geothermal exploration: Salt Lake City, 
Utah, University of Utah, unpublished Masters thesis, $85 \mathrm{p}$.

SANDQUIST, G. M., Rogers, V. C., and Betts, J. F., 1972, Prospective nuclear-stimulated geothermal resources in Utah: American Nuclear Society, Transactions, v. 15, no. 2, p. 622-623.

SARGENT, K. A., and Hansen, D. E., 1976, General geology and mineral resources of the coal area of southcentral Utah: U.S. Geological Survey Open-File Report $76-811,122 \mathrm{p}$.

SASS, J. H., Blackwell, D. D., Chapman, D. S., Costain, J. K., Decker, E. R., Lawver, L. A., and Swanberg, C. A., 1981, Heat flow from the crust of the United States, chap. 13 of Touloukian, Y. S., Judd, W. R., and Roy, R. F., eds., Physical properties of rocks and minerals: New York, McGraw-Hill, p. 503-548.

SASS, J. H., Diment, W. H., Lachenbruch, A. H., Marshall, B. V., Munroe, R. J., Moses, T. H., Jr., and Urban, T. C., 1976, A new heat-flow contour map of the conterminous United States: U.S. Geological Survey Open-File Report 76-756, 24 p.

SASS, J. H., and Lachenbruch, A. H., 1979, Heat flow and conduction-dominated thermal regimes, in Muffler, $L$. J. P., ed., Assessment of geothermal resources of the United States-1978: U.S. Geological Survey Circular 790, p. 8-11.

Updates U.S. Geological Survey Circular 726 (1975); updates heat flow information; heat flow maps of the United States; published sources for heat flow maps.

SASS, J. H., Lachenbruch, A. H., Munroe, R. J., Greene, G. W., and Moses, T. H., Jr., 1971, Heat flow in the western United States: Journal of Geophysical Research, v. 76 , no. 26 , p. 6376-6413.

SASS, J. H., Lachenbruch, A. H., and Smith, E. P., 1983a, Temperature profiles from Salt Valley, Utah, thermal conductivity of 10 samples from drill hole DOE 3, and preliminary estimates of heat flow: U.S. Geological Survey Open-File Report 83-455, 21 p.

Temperature profiles from nine wells; thermal conductivity measurements from ten samples representative of formations in area; preliminary estimates of heat flow obtained from oil wells in area; temperature-depth profiles; table of thermal conductivity of samples.

SASS, J. H., Lachenbruch, A. H., and Smith, E. P., 1983b, Thermal data from well GD-1, Gibson Dome, Paradox Valley, Utah: U.S. Geological Survey Open-File Report $83-476,15 \mathrm{p}$

Temperature data obtained from well GD-1 to a depth of 1900 meters; thermal conductivity of samples of major formations in study area; heat flow estimates for individual formations; tables of thermal conductivities of samples; temperature profile; heat flow calculations.
SASS, J. H., and Munroe, R. J., 1974, Basic heat-flow data from the United States: U.S. Geological Survey OpenFile Report 74-9, 426 p.

SAVINO, J. M., Rodi, W. L., and Masso, J. F., 1982, Inversion modeling of multiple geophysical data sets for geothermal exploration: application to Roosevelt Hot Springs area - final report: National Technical Information Service Report, no. DOE/ID/12067-13, 119 p.

Theoretical basis for modeling arrival times of earthquake $\mathbf{P}$ waves at seismic stations; data sets of local earthquake arrival times; gravity data; threedimensional inversion model obtained from joint inversion of seismic and gravity data; figures showing layers in inversion model; comparison of observed and predicted gravity from inversion model.

SAWYER, R. F., 1977, Gravity and ground magnetic surveys of the Thermo Hot Springs KGRA Region, Beaver County, Utah: Sait Lake City, Utah, University of Utah, unpublished Masters thesis, $142 \mathrm{p}$.

See Sawyer and Cook (1977).

SAWYER, R. F., and Cook, K. L., 1977, Gravity and ground magnetic surveys of the Thermo Hot Springs KGRA region Beaver County, Utah: University of Utah, Department of Geology and Geophysics Technical Report, v. 77-6, 42 p.

Purpose of gravity and magnetic surveys; geology of area; gravity and magnetic data acquisition, reduction, and interpretation; maps of detailed gravity and magnetics; three-dimensional models from gravity and magnetic data; gravity and magnetic profiles.

SCHAFF, S. C., 1981, Seismic monitoring and potential for induced seismicity at Roosevelt Hot Springs, Utah and Raft River, Idaho (abs.), in Seismological Society of America, 76th annual meeting: Earthquake Notes v. 52, no. 1, p. 30.

Monitoring of production activity at Roosevelt and Raft River KGRAs (before and after development of power plants) through the use of seismograph arrays; evaluates effect of reinjection of waste water produced at power plants on earthquake potential.

SCHMOKER, J. W., 1972, Analysis of gravity and aeromagnetic data, San Francisco Mountains and vicinity, southwestern Utah: Utah Geological and Mineral Survey Bulletin 98, 24 p.

SCHOLZ, C. H., Barazangi, M., and Sbar, M. L., 1971, Late Cenozoic evolution of the Great Basin, western United States, as an ensailic interarc basin: Geological Society of America Bulletin, v. 82, no. 11, p. 2979-2990.

SCHUBERT, Gerald, and Anderson, O. L., 1974, The earth's thermal gradient: Physics Today, v. 27, no. 3, p. 28-34.

SCHUFLE, J. A., 1963, Minerals and energy sources in the arid west: the challenge of arid lands in the United States, in Hodge, C., ed., Aridity and man: American 
Association for the Advancement of Science Publication 74, p. 173-213.

SEISMIC EXPLORATION INCORPORATED, 1977, Getty Oil Company surface geophysical surveys, Roosevelt Hot Springs: Earth Science Laboratory/University of Utah Research Institute Open-File Report, no. UT/RHS/GOC-1.2, unpaginated.

Fifteen and three quarter square miles ground motion survey; computer analysis of the five stations; seismic emmissions study; maps of seismic emmission anomalies at seismic stations.

SELK, D. C., 1976, Crustal and upper-mantle structures in Utah as determined by gravity profiles: Salt Lake City, Utah, University of Utah, unpublished Master thesis, $81 \mathrm{p}$.

SENTERFIT, R. M., and Bedinger, G. M., 1976, Audiomagnetotelluric data $\log$, station location map and skin depth pseudo-sections, Crater Hot Springs known geothermal resource area, Utah: U.S. Geological Survey Open-File Report 76-245, 3 p.

SERPA, L. F., 1980, Detailed gravity and aeromagnetic surveys in the Black Rock Desert area, Utah: Salt Lake City, Utah, University of Utah, unpublished Masters thesis, $210 \mathrm{p}$.

SERPA, L. F., and Cook, K. L., 1979, Detailed gravity and aeromagnetic surveys in the Black Rock Desert area, Utah (abs.): Society of Exploration Geophysicists, Annual International Meeting, Abstracts 49, p. 106-107; also, 1980, Earth Science Laboratory/University of Utah Research Institute Report, no. IDO/DOE/ET/28392/39, $210 \mathrm{p}$.

SHANNON, S. S., Jr., Goff, F., Rowley, J. C., Pettitt, R. A., and Vuataz, F. D., 1983, Roosevelt Hot Springs/hot dry rock prospect and evaluation of the Acord 1-26 well: Geothermal Resources Council, Transactions, v. 7, p. 541-544.

Location of Roosevelt Hot Springs KGRA; geology and Tertiary volcanic history; temperature and thermal gradient ranges; conductive heat and reservoir volume estimates; geophysical and geologic similarities of other Basin and Range prospects to Roosevelt Hot Springs; drilling history of Acord 1-26 well; well log information; average temperature gradients and calculated heat flow of Acord 1-26 well; interpretations of basement structures from three seismic lines; suggestions for relocating hot dry rock wells; chemistry of shallow aquifers and deep hydrothermal systems; production capacities of aquifers.

SHANNON, S. S., Jr., Pettitt, R., Rowley, J., Goff, F., Mathews, M., and Jacobson, J. J., 1983, Acord 1 - 26 hot, dry well, Roosevelt Hot Springs hot dry rock prospect, Utah: Los Alamos National Laboratory Report LA-9857-HDR, $16 \mathrm{p}$.

See Shannon, Goff, and others (1983).
SHAWE, D. R., 1972, Reconnaissance geology and mineral potential of Thomas, Keg, and Desert calderas, central Juab County, Utah: U.S. Geological Survey Professional Paper 800-B, p. B67-B77.

SHIRLEY, Kathy, 1984, Utah prison turns to geothermal: American Association of Petroleum Geologists Explorer, v. 5 , no. 15 , p. 28-29.

SIBBETT, B. S., and Nielson, D. L., 1980, Geology of the central Mineral Mountains, Beaver County, Utah: Earth Science Laboratory/University of Utah Research Institute Report, no. DOE/ET/28392-40, 42 p.

SIDLE, W. C., 1984, Carbon monoxide as a geothermal indicator at Meadow-Hatton KGRA, west-central Utah: Geothermal Resources Council Bulletin, v. 13, no. 6, p. 13-18.

Use of soil-gas measurements for geothermal exploration; recent volcanism in the study area; local geologic structure and warm spring occurrences; geologic map of sample area; map of potentiometric surface including flow paths of semi-confined aquifer of sample area; ground-water patterns and submerged structures; over 900 soil-gas samples collected at an 800 meter spacing near Filmore, Utah; equipment and analytical techniques used; $\mathrm{CO}$ and $\mathrm{CO}_{2}$ anomalies and their distributions; differences between the $\mathrm{CO}$ and $\mathrm{CO}_{2}$ anomalies; relationship of geochemical anomalies to ground-water patterns; conclusions.

SIFFORD, Alex, 1981, Legal treatment of geothermal resources in BPA marketing area states: Geothermal Resources Council, Transactions, v. 5, p. 619-622.

SILL, W. R., 1981, Extended self-potential survey, Roosevelt Hot Springs KGRA, Utah: Earth Science Laboratory/University of Utah Research Institute Open-File Report, no. UT/RHS/ESL-2, 8 p.

Updates and extends self-potential survey map of Sill and Johng (1979); resistivity and geology of Roosevelt Hot Springs; maps of self-potential and locations of selfpotential survey lines.

SILL, W. R., 1982, Diffusion coupled (electrochemical) self-potential effects in geothermal areas: Earth Science Laboratory/University of Utah Research Institute Report, no. DOE/ID/12079-73, 29 p.

Previous studies of self-potential anomalies across geothermal systems; scope of paper; effective mobilities of cations and anions in electrolytic solutions; mathematical calculations describing electrochemical concentrations; equations used to describe flux of solute ions and total electric current; pure ambipolar diffusion equations and potential gradient equation; equations describing electrical effects generated by the diffusion of ions and the divergence conditions; application of mathematical calculations to non-linear geothermal problems; ranges of diffusion potential of 20 rock samples; equations relating permeability and pore size to surface conductivity; 
electrical conductivity measurements at Roosevelt Hot Springs; results of mathematical modeling at Roosevelt.

SILL, W. R., and Bodell, J., 1977, Thermal gradients and heat flow at Roosevelt Hot Springs: University of Utah, Department of Geology and Geophysics Report, no. $77-3,46 \mathrm{p}$.

Temperature profiles and contour maps of thermal gradients.

SILL, W. R., Bostick, F. X., Hohmann, G. W., Petrick, W., Phillips, R. J., Stodt, J., Swift, C. M., Jr., Tripp, A., and Ward, S. H., 1977, Resistivity structure in southwestern Utah based on magnetotelluric and deep resistivity measurements (abs.): Geophysics, v. 42, no. 7, p. 1539.

SILL, W. R., Chapman, D. S., Wilson, W., and Bodell, J., 1977, Thermal gradients and heat flow at Roosevelt Hot Springs KGRA: Geophysics, v. 42 , no. 7, p. 1539

Measurement of thermal gradients from 39 shallow drill holes; resulting contour map; measurements of thermal conductivity obtained from alluvium.

SILL, W. R., and Johng, D. S., 1979, Self-potential survey, Roosevelt Hot Springs, Utah: University of Utah Department of Geology and Geophysics Report, no. DOE/ET/28392-21, 19 p.

Possible source of self-potential (SP) anomalies in geothermal areas; history of SP studies at Roosevelt Hot Springs; measurement procedures and results; graph of SP profile and correlation to the thermal system; SP contour map of Roosevelt Hot Springs; brief analysis of the SP pattern and speculation on source(s) of SP anomalies; appendix discussing electrokinetic coupling and thermoelectric coupling.

SILL, W. R., and Ward, S. H., 1978, Electrical energizing of well casings: University of Utah, Department of Geology and Geophysics Final Report, v. 77-8, 10 p.

SILL, W. R., Ward, S. H., Parry, W. T., Tripp, A., and Swift, C. M., Jr., 1977, Electrical and geochemical models of the near-surface zone at Roosevelt Hot Springs KGRA, Utah (abs.): Geophysics, v. 42, no. 1, p. 182.

Modeling of dipole-dipole resistivity surveys at Roosevelt Hot Springs; results of model studies; methods used to determine the contribution of clays to electrical conductivity; relation of increased resistivity to a $\mathrm{K}$ feldspar stable region.

SILL, W. R., Wilson, W. R., Bodell, J., Ward, S. H., and Chapman D. S., 1977, Heat flow measurements in southern Utah and the northern Basin and RangeColorado Plateau transition (abs.): EOS Transactions, American Geophysical Union, v. 58 , no. 12 , p. $1237-1238$.

SKALKA, Morris, 1979, The division of geothermal energy (U.S. Department of Energy) direct heat applications program: Geothermal Resources Council, Transactions, v. 3, p. 655-658.
SMEDleY, J. E., Pera, E. M., and Lutz, G. A., 1976, Leasable mineral and waterpower land classification map of the Escalante quadrangle, Utah-Arizona: U.S. Geological Survey Open-File Report 76-827, scale $1: 250,000$.

SMEDLEY, J. E., Pera, E. M., and Lutz, G. A., 1977, Leasable mineral and waterpower land classification map, Salina quadrangle, Utah: U.S. Geological Survey Open-File Report 77-548, two sheets, scale 1:250,000.

SMEDLEY, J. E., Pera, E. M., Simpson, L. A., and Lutz, G. A., 1978, Leasable mineral and waterpower land classification map of the Price quadrangle, Utah: U.S. Geological Survey Open-File Report 78-338, scale $1: 250,000$.

SMITH, Christian, 1980, Aeromagnetic maps of Crystal Hot Springs: Earth Science Laboratory/University of Utah Research Institute, scale: 1:24,000.

Map showing three-layer prism model aeromagnetic data from Crystal Hot Springs area; map showing prisms and susceptibilities of two lowest layers; observed aeromagnetic map of Crystal Hot Springs area.

SMITH, G. E., 1977, Roosevelt Hot Springs geothermal find: Geothermal Energy, v. 5, no. 1, p. 14-16.

Location of the Roosevelt geothermal system; steam and water production rate of one well; ownership and development of area; history and general geology; field trip program schedule; history of Phillips Petroleum Company's exploration efforts; speculations on geothermal potential of southern Utah.

SMITH, J. H., 1962, Geothermal energy: United Nations Symposium on New Sources of Energy, Rome. Italy, 1961 , v. 2, p. 67-73.

SMITH, J. L., Isselhardt, C. F., and Matlick, J. S., 1978, Summary of 1977 geothermal drilling; western United States: Geothermal Energy, v. 6, no. 5, p. 11-19.

SMITH, J. L., Isselhardt, C. F., Matlick, J. S., and Darwin, K. L., 1977, Summary of 1976 geothermal drilling, western United States, in Geothermal world directory, 1977/78 edition: Geothermal World Publications, p. 256-263; also, Geothermal Energy, v. 5, no. 5, p. 8-17.

SMITH, J. L., and Matlick, J. S., 1976, Summary of 1975 geothermal drilling, western United States: Geothermal Energy, v. 4, no. 6, p. 28-31.

SMITH, J. L., Matlick, J. S., and Ehni, W. J., 1980, Summary of 1979 geothermal drilling, western United States: Geothermal Energy, v. 8, no. 7, p. 3-14.

SMITH, J. L., Matlick, J. S., and Isselhardt, C. F., 1979, Summary of the 1978 geothermal drilling, western United States: Geothermal Energy, v. 7, no. 5, p. 25-34.

SMITH, Leslie, and Chapman, D. S., 1982, The effects of regional ground water flow on the thermal regime of a basin: Earth Science Laboratory/University of Utah Research Institute Report, no. DOE/ID/12079-65, 68 p. 
SMITH, Leslie, 1980, Model study of the regional hydrogeologic regime, Roosevelt Hot Springs, Utah: Earth Science Laboratory/University of Utah Research Institute Report, no. DOE/ET/28392-44, 36 p.

Basis of model used to investigate potential recharge areas of Roosevelt thermal area; regional geology summarized in a hydrologic context; review of modeling techniques and model limitations; results of sensitivity analysis and implications for interbasin flow; table showing figures of hydraulic head distribution along cross section; basic hydrologic configuration.

SMITH M. C., Nunz, G. J., and Ponder, G. M., 1982, Hot dry rock geothermal energy program: Los Alamos National Laboratory Report, no. LA-9780-HDR, 127 p.

SMITH, M. C., Nunz, G. J., and Wilson, M. G., compilers, 1985 , Hot dry rock geothermal energy development program annual report fiscal year 1983: Los Alamos National Laboratory Report, no. LA-10347-HDR, 91 p.

SMITH M. C., and Ponder, G. M., 1982, Hot dry rock geothermal energy development program annual report fiscal year 1981: Los Alamos National Laboratory Report, no. LA-9287-HDR, 140 p.

SMITH, M. R., 1979, Utah mineral industry activity review 1979: Utah Geological and Mineral Survey Circular 68, p. 14-15.

SMITH, M. R., 1982, Utah synfuels update: Utah Geological and Mineral Survey, Survey Notes, v. 16, no. 3, p. 10.

SMITH, R. B., 1977a, Long-term seismic monitoring of the Roosevelt-Cove Fort KGRAs: University of Utah, Department of Geology and Geophysics Report, no. 77-3, 5 p.

Three RF telemetered, vertical component seismograph stations used to monitor Roosevelt-Cove Fort earthquakes; recording procedures; number of quakes registered between January 1 and June 30, 1977 in the Cove Fort area and near Roosevelt Hot Springs; seismic signals generated by steam withdrawl from a well at Roosevelt; conclusions.

SMITH, R. B., 1977b, Seismicity in geothermal areas of the Intermountain Seismic Belt (abs.): EOS Transactions, American Geophysical Union, v. 58, no. 12, p. 1187.

SMITH, R. B., and Sbar, M., 1974, Contemporary tectonics and seismicity of the western states with emphasis on the intermountain seismic belt: Geological Society of America Bulletin, v. 85, no. 8, p. 1205-1218.

SMITH, R. L., and Luedke, R. G., 1981, Potentially active volcanic lineaments and loci in the western conterminous United States (abs.): EOS Transactions, American Geophysical Union, v. 62, no. 45, p. 1079.

SMITH, R. L., and Shaw, H. R., 1973, Volcanic rocks as geologic guides to geothermal exploration and evaluation (abs.): EOS Transactions, American Geophysical Union, v. 54, no. 11, p. 1213.
SMITH, R. L., and Shaw, H. R., 1975, Igneous-related geothermal systems, in White, D. E., and Williams, D. L., Assessment of geothermal resources of the United States-1975: U.S. Geological Survey Circular 726, p. 58-83.

Numerical estimates of the igneous-related heat content of thermal anomalies; silicic magma contribution to the bulk of stored heat in upper crust; evaluates geothermal potential of volcanic areas in the western United States; tables of magnitude and heat contents of identified volcanic systems; thermal calcuation model; mentions six areas of Utah with identified volcanic systems.

SMITH, R. L., and Shaw, H. R., 1979, Igneous-related geothermal systems, in Muffler, L. J. P., ed., Assessment of geothermal resources of the United States-1978: U.S. Geological Survey Circular 790, p. 12-17.

Updates U.S. Geological Survey Circular 726 (1975); updates and refines data base on geothermal systems associated with igneous rocks; estimates thermal energy remaining in igneous related geothermal systems - both unevaluated and undiscovered systems; effects of hydrothermal circulation on cooling model; longevity of magmatic system versus hydrothermal cooling; mentions Mineral Mountains, Cove Creek Domes, and Thomas Range igneous systems of Utah.

SMITH, R. L., Shaw, H. R., Luedke, R. G., and Russell, S. L., 1978, Comprehensive tables giving physical data and thermal energy estimates for young igneous systems of the United States: U.S. Geological Survey Open-File Report 78-925, $28 \mathrm{p}$.

SMITH, T. B., 1974, Gravity study of the Fumarole Butte area, Juab and Millard Counties, Utah: Salt Lake City, Utah, University of Utah, unpublished Masters thesis, $54 \mathrm{p}$.

Location of gravity survey; purpose of investigation; previous investigations; regional and local geology of study area; three gravity surveys with 500 stations; instruments used and field techniques; data reduction techniques; error analysis procedures; table showing rock densities of surface samples in study area; correlation of gravity data with lithologic logs obtained from local water wells; well logs obtained from the Gulf Oil Corporation Gronning ffl Well; aeromagnetic map of thesis area; geophysical techniques; analysis and interpretation of gravity data; plate showing a simple Bouguer gravity anomaly map; gravity profiles across area; summary and conclusions.

SMITH, T. B., Cook, K. L., and Peeples, W. J., 1978, Gravity study of the Fumarole Butte area, Juab and Millard Counties, Utah: Utah Geology, v. 5, no. 1, p. 37-56. See Smith (1974).

SMITH, T. C., and Sharda, B. D., 1978, Geothermal environmental report socioeconomics: University of Utah 
Research Institute Environmental Studies Laboratory, Report, no UCRL-13955, v. 2, 9.5 p.

SNOW, J. H, 1978, Study of structural and tectonic patterns in south-central Utah as interpreted from gravity and aeromagnetic data: Salt Lake City, Utah, University of Utah, unpublished Masters thesis, $245 \mathrm{p}$.

SNOW, Nick, and Madsen, R., 1978, Monroe, Utah officials unveil plan for geothermal heat: Geothermal Energy Magazine, v. 6, no. 2, p. 21-23.

Two November 1977 Deseret News articles that announce plans for implementation of a $\$ 1.5$ million geothermal heating system, designed by Terra Tek, at Monroe Hot Springs.

SOREY, M. L., 1975, Numerical modeling of liquid geothermal systems: U.S. Geological Survey Professional Paper 1044-D, 25 p.

SOREY, M. L., Reed, M. J., Mariner, R. H., and Nathenson, M., 1982, Assessment of low-temperature geothermal resources in the United States: Geothermal Resources Council, Transactions. v. 6. v. 479-48?

SPICER, H. C., 1964, A compilation of deep earth temperature data: USA 1910-1945: U.S. Geological Survey Open-File Report 64-147, 74 p.

SPICER, H. C., 1965, Geothermal gradients and heat flow in the Salt Valley anticline, Utah (abs.): Geophysical Abstracts, no. 217, p. 137.

STANLEY, W. D., Boehl, J. E., Bostick, F. X., and Smith, H. W., 1977, Geothermal significance of magnetotelluric sounding in the eastern Snake River plain-Yellowstone region: Journal of Geophysical Research, v. 82, no. 17, p. 2501-2514.

STEARNS, N. D., Stearns, H. T., and Waring, G. A., 1937, Thermal springs in the United States: U.S. Geological Survey Water-Supply Paper 679-B, p. B59-B206.

STEVEN, T. A., 1979, Geologic map of the Monroe NW quadrangle, west-central Utah: U.S. Geological Survey Miscellaneous Field Studies Map MF-1107, scale $1: 24,000$.

STEVEN, T. A., Cunningham, C. G., and Anderson, J. J., 1984, Geologic history and uranium potential of the Big John caldera, southern Tushar Mountains, in, Steven, T. A., ed., Igneous activity and related ore deposits in the western and southern Tushar Mountains, Marysvale volcanic field, west-central Utah: U.S. Geological Survey Professional Paper 1299B, p. 25-33.

STEVEN, T. A., Cunningham, C. G., Naeser, C. W., and Mehnert, H. H., 1979, Revised stratigraphy and radiometric ages of volcanic rocks and mineral deposits in the Marysvale area, west-central Utah: U.S. Geological Survey Bulletin 1469, $40 \mathrm{p}$.

STEVEN, T. A., and Morris, H. T., 1983a, Geologic map of the Cove Fort quadrangle, west-central Utah: U.S.
Geological Survey Miscellaneous Investigation Series Map I-1481, scale 1:50,000.

STEVEN, T. A., and Morris, H. T., 1983b, Geology of the Richfield quadrangle, west-central Utah: U.S. Geological Survey Open-File Report 83-583, scale 1:250,000.

STEVEN, T. A., and Morris, H. T., 1984, Mineral resource potential of the Richfield $1 \times 2$ degree quadrangle, westcentral Utah: U.S. Geological Survey Open-File Report 84-521, $53 \mathrm{p}$.

STEVEN, T. A., Rowley, P. D., and Cunningham, C. G., 1978, Geology of the Marysvale volcanic field, westcentral Utah: Brigham Young University Geology Studies, v. 25, pt. 1, p. 67-70.

STEVEN, T. A., Rowley, P. D., and Cunningham, C. G., 1984, Calderas of the Marysvale volcanic field west central Utah: Journal of Geophysical Research, v. 89, no. B10, p. 8751-8764.

STEWART, J. H., 1971, Basin and Range structure: a system of horsts and grabens produced by deep-seated extension: Geological Society of America Bulletin, v. 82, no. 4, p. 1019-1044.

STEWART, J. H., 1983, Cenozoic structure and tectonics of the northern Basin and Range Province, California, Nevada, and Utah, in The role of heat in the development of energy and mineral resources in the northern Basin and Range Province: Geothermal Resources Council Special Report 13, p. 25-40.

STEWART, J. H., Moore, W. J., and Zietz, I., 1977, Eastwest patterns of Cenozoic igneous rocks, aeromagnetic anomalies, and mineral deposits, Nevada and Utah: Geological Society of America Bulletin, v. 88, no. 1, p. 67-77.

STOWER C. H., 1977, Utah mineral industry activity for 1976: Utah Geological and Mineral Survey, Survey Notes, v. 11, no. 2, p. 3-13.

STRINGFELLOW, J. R., ed., 1982, The industry coupled case study program final report: Earth Science Laboratory/University of Utah Research Institute Report, no. DOE/ID/12079-81, 108 p.

Purpose of program; role of the Earth Science Laboratory in study; collection of reports and abstracts from Basin and Range known geothermal resource areas describing geology, geophysical surveys, geochemical exploration, well logs, and stable isotope studies (Roosevelt, Cove Fort- Sulphurdale, and Monroe, Utah); collection of reports that are an indirect result of the industry coupled program; list of open-file reports, sample locations, and depths of drill holes at Cove FortSulphurdale, Roosevelt, and other Basin and Range areas.

SUNG, R., Houser, G., Strehler, D., and Scheyer, K., 1979, Sampling and analysis of potential geothermal sites: TRW Environmental Engineering Division 
Report, Contract no. 68-03-2560, Work Detective T-5007, $167 \mathrm{p}$.

SWANBERG, C. A., 1974, Application of the Na-K-Ca geothermometer to thermal areas of Utah and the Imperial Valley, California: Geothermics, v. 3, no. 2, p. 53-59.

SWANBERG, C. A., Morgan, P., Stoyer, C. H., and Witcher, J. C., 1977, An appraisal study of the geothermal resources of Arizona and adjacent areas in New Mexico and Utah and their value for desalination and other uses: New Mexico Energy Institute, Research Project, Technical Report 6-1, p. 1-88.

SWANSON, J. R., 1977, GEOTHERM user guide: U.S. Geological Survey Open-File Report 77-504, 53 p.

TALMAGE, S. B., 1929, Thermal springs near the Wasatch fault (abs.): Geological Society of America Bulletin, v. 40, no. 1 , p. 181 .

Samples from 12 springs along the Wasatch fault; chemical characteristics of spring water; origin of springs.

TERRA TEK, 1980a, Environmental report Utah state prison geothermal project: Terra Tek Report, no. TR 80-25, 35 p.

TERRA TEK, 1980b, Monroe KGRA, Monroe, Utah-background information for the Geothermal Resources Council field trip September 12-13, 1980: Terra Tek Report, no. TR 80-31, 23 p.

Structural control of the geothermal system; general stratigraphy and structure of area; alteration map of the Monroe KGRA; generalized cross section of the Sevier fault; gravity anomaly map of MarysvaleMonroe-Joseph area; map of resistivity contours; thermal gradient profiles across the Monroe mound and graph of temperature profiles in eight thermal gradient and test holes; chemical analysis of production well water; geothermometry interpretations; drilling problems, procedures, and results of a production test well; summary and conclusions.

TESHIN, V. N., Swanson, J. R., and Orris, G. J., 1979, GEOTHERM - GEOTHERM resources file: Geothermal Resources Council, Transactions, v. 3, p. 721-724.

THANGSUPHANICH, Ittichai, 1976, Regional gravity survey of the southern Mineral Mountains, Beaver County, Utah: Salt Lake City, Utah, University of Utah, unpublished Masters thesis, $38 \mathrm{p}$.

THEBERGE, A. E., Jr., 1980, The state geothermal mapping program: Geothermal Resources Council Bulletin, v. 9 , no. 11, p. $3-4$.

Data to be published on geothermal maps for each state; NOAA list of 1702 thermal spring locations for the United States; information included in addition to lists; management logistics for the State Resource Assessment Program; NOAA's responsibilities within the mapping program; list of individual state investigators who compile geothermal information.
THERMAL POWER COMPANY, 1976, Well Utah State 14-2 ML-27536 Roosevelt field, Beaver County, Utah: Earth Science Laboratory/University of Utah Research Institute Open-File Report, no. UT/RHS/TPC-1, unpaginated.

General well specifications; bore hole data; production and reservoir data; chemical analyses of well fluids; well summary.

THERMAL POWER COMPANY, 1977a, Well Utah State 14-2 ML-27536 Roosevelt field, Beaver County, Utah chemical analyses, flow test, geophysical logs: U.S. Geological Survey Water Resource Division Analytical Statement, Laboratory no. GT293AT76, unpaginated.

Chemical analysis of Utah State 14-2 well fluids; report of tests conducted on well 14-2 to determine the flow regime within the well; chart showing generalized geology and selected geophysical logs; tritium analysis of Utah State 14-2 samples; chip sample preparation charts; summary of data acquisition by the Denver Research Institute at the well.

THERMAL POWER COMPANY, 1977b, Well Utah State 72-16 ML25128 Roosevelt field, Beaver County, Utah: Earth Science Laboratory/University of Utah Research Institute Open-File Report, no. UT/RHS/TPC-2, unpaginated.

General well specifications; borehole data; production and reservoir data; water analysis.

THOMAIDIS, N. D., 1974, Developments in Four Corners-intermountain area in 1973: American Association of Petroleum Geologists Bulletin, v. 58, no. 8, p. 1581-1585.

TISCHLER, M. S., Oesterling, W. A., and Bonham, H. F., Jr., 1964, Minerals for industry, summary of geological survey of 1955-1961, v. 1 - northern Nevada and northwestern Utah: Southern Pacific Company, San Francisco, California, $188 \mathrm{p}$.

TRIPP, A. C., 1978, Electromagnetic and Schlumberger sounding in the Roosevelt Hot Springs KGRA, Utah: Salt Lake City, Utah, University of Utah, unpublished Masters thesis, 110 p.; also, Geophysics, v. 43, no. 7, p. 1450-1469.

Use of 50 magnetic dipole and 21 resistivity soundings to obtain finer resolution of the vertical geoelectric section; electromagnetic and Schlumberger measurements; procedure for inversion of data to one- and twodimensional conductivity models; modeling results; procedure for simultaneous inversion models from magnetic and resistivity soundings; geologic interpretation of reservoir configuration.

TRIPP, A. C., Ward, S. H., Sill, W. R., Swift, C. M., Jr., and Petrick, W. R., 1976, Electromagnetic and Schlumberger resistivity sounding in the Roosevelt KGRA, Utah (abs.): Society of Exploration Geophysicists 
Annual International Meeting Abstracts, no. 46, p. 89-90.

See Tripp (1978).

TRUESDELL, A. H., 1973, ENTHALP, a computer program for calculation of aquifer chemistry: U.S. Geological Survey National Technical Information Service Report PB 219-376, 74 p.

TRUESDELL, A. H., 1976, GEOTERM, a geothermometric computer program for hot-spring systems: United Nations symposium on the development and use of geothermal resources, 2d, San Francisco, California, 1975, Proceedings, v. 1, p. 831-836.

TRW SYSTEMS GROUP, 1975, A study of geothermal prospects in the western United States: Final Report: TRW Systems Corporation, Redondo Beach, California, $147 \mathrm{p}$.

TRW SYSTEMS GROUP, 1976, Study of geothermal prospects in the western United States: Geothermal Energy Report, no. NP-20997, 133 p.

TUCKER, R. E., Miller, W. R., and McHugh, J. B., 1980, Geochemical results from a natural waters study in the Mount Belknap caldera and vicinity, Utah: U.S. Geological Survey Open-File Report 80-1051, 53 p.

TURLEY, C. H., and Nash, W. P., 1980, Studies in late Cenozoic volcanism in west-central Utah; Part 1, Petrology of late Tertiary and Quaternary volcanism in western Juab and Millard Counties, Utah: Utah Geological and Mineral Survey Special Studies 52, p. 1-33.

TURLEY, C. H., Nash, W. P., and Brown, F. H., 1979, Petrology and geochronology of late Tertiary and Quaternary volcanic rocks in the eastern margin of the Basin and Range Province, Utah: University of Utah, Department of Geology and Geophysics Final Report, v. 1, contract no. 14-08-0001-G-343, 78 p.

TUTTLE, Jerry, Coe, B. A., Gertsch, W. D., and Meyer, R. T., 1980, State geothermal commercialization programs in seven Rocky Mountain States: semi-annual progress report, January-June 1980: National Technical Information Service Report, no. DOE/ID/12101-2, 343 p.

UNION OIL COMPANY, 1973, Union Oil Company general area studies - Cove Fort regional gravity interpretations: Earth Science Laboratory/University of Utah Research Institute Open-File Report, no. UT/CFS/UOC-1.5, unpaginated.

Maps of Bouguer gravity survey; tables of basic gravity corrections for latitude, curvature, free air, Bouguer, and terrain.

UNION OIL COMPANY, 1974, Union Oil Company, general area studies - geochemical survey, Cove Fort, Utah: Earth Science Laboratory/University of Utah Research Institute Open-File Report, no. UT/CFS/UOC-1.6, 4 p.
Geochemical surveys; mercury trace analyses of temperature gradient drill hole samples and of surface samples.

UNION OIL COMPANY, 1976a, Union Oil Company, general area studies - seismic survey, Cove Fort, Utah: Earth Science Laboratory/University of Utah Research Institute Open-File Report, no. UT/CFS/UOC-1.3, unpaginated.

Seismic survey; interpretation of nine seismic lines.

UNION OIL COMPANY, 1976b, Union Oil Company, general area studies - temperature gradient study, Cove Fort, Utah: Earth Science Laboratory/University of Utah Research Institute Open-File Report, no. UT/CFS/UOC-1.1, unpaginated.

Temperature gradients of 25 shallow holes at the Cove Fort prospect; temperature readings obtained at various depths and dates.

UNION OIL COMPANY, 1978a, Geologic report of the Cove Fort-Sulphurdale geothermal unit area, Millard and Beaver Counties, Utah: Earth Science Laboratory/University of Utah Research Institute Open-File Report, no. UT/CFS/UOC-1.2, 33 p.

Stratigraphy; sample logs of water wells; geothermal reservoir geology and structure; temperature gradient well data; geochemical analyses of drill cuttings; maps of geology, topography, aeromagnetics, Bouguer gravity, temperature gradients, geochemical patterns, and surface geothermal manifestations; geologic cross sections; temperature profiles.

UNION OIL COMPANY, 1978b, Union Oil Company Cove Fort-Sulphurdale well Forminco 1, Cove Fort field: Earth Science Laboratory/University of Utah Research Institute Open-File Report, no. UT/CFS/UOC-2, unpaginated.

Technical report including well summary, well and mud histories, and geology; formation lithologies; fluid geochemistry; comparison of hydrothermal alteration at Cove Fort with that at the Tintic district.

UNION OIL COMPANY, 1978c, Union Oil Company Cove Fort-Sulphurdale well 31-33 - geothermal log and directional survey: Earth Science Laboratory/University of Utah Research Institute Open-File Report, no. UT/CFS/UOC-7, 45 p.

Geothermal/geologic data log and summary of Schlumberger directional survey.

UNION OIL COMPANY, 1978d, Union Oil Company Cove Fort-Sulphurdale well 31-33 - technical report: Earth Science Laboratory/University of Utah Research Institute Open-File Report, no. UT/CFS/UOC-6, unpaginated.

Technical report including well summary and history, geology, and temperature-pressure survey; formation lithologies; fluid chemistries; temperature profiles; logging data. 
UNION OIL COMPANY, 1978e, Union Oil Company Cove Fort-Sulphurdale well 42-7 - caliper and directional surveys: Earth Science Laboratory/University of Utah Research Institute Open-File Report, no. UT/CFS/UOC-4, 23 p.

Dialog caliper; Schlumberger directional surveys; table of directional $\log$ with cross sections to west and north.

UNION OIL COMPANY, 1978f, Union Oil Company Cove Fort-Sulphurdale well 42-7 - flow tests: Earth Science Laboratory/University of Utah Research Institute Open-File Report, no. UT/CFS/UOC-3.2, 7 p.

Initial flow test results; temperature, chemical, production, injection, and permeability data on production and injection tests.

UNION OIL COMPANY, 1978g, Union Oil Company Cove Fort-Sulphurdale well 42-7 - technical report: Earth Science Laboratory/University of Utah Research Institute Open-File Report, no. UT/CFS/UOC-3.1, unpaginated.

Well summary and history; fluid history; bit record; formation lithologies; fluid geochemistry; estimation of subsurface temperatures from silica, potassium, calcium, and sodium geothermometers; geochemical analyses of core samples.

UNION OIL COMPANY, 1979a, Union Oil Company Cove Fort-Sulphurdale well 14-29 - Schlumberger directional survey: Earth Science Laboratory/University of Utah Research Institute Open-File Report, no. UT/CFS/UOC-9, 3 p.

Schlumberger directional survey summary; formation lithologies; fluid chemistries; temperature profiles; well summary; logging data; fluid analysis.

UNION OIL COMPANY, 1979b, Union Oil Company Cove Fort-Sulphurdale well 14-29 - technical report: Earth Science Laboratory/University of Utah Research Institute Open-File Report, no. UT/CFS/UOC-8, unpaginated.

Technical report with well summary and history; geologic report; temperature-pressure survey; formation lithologies; fluid geochemistry; temperature profiles.

UNIVERSITY OF DENVER, Denver Research Institute, 1978, Geothermal well Utah State 14-2, Roosevelt KGRA, Utah: Earth Science Laboratory/University of Utah Research Institute Open-File Report, no. UT/RHS/DRI-1, unpaginated.

Preliminary reservoir flow results; flow rate meaurements; flow rate well log.

U.S. GEOLOGICAL SURVEY, 1972a, Aeromagnetic map of parts of the Delta and Richfield 1x2 degree quadrangles, Utah: U.S. Geological Survey Open-File Report 72-385, scale 1:250,000.

U.S. GEOLOGICAL SURVEY, 1972b, Aeromagnetic map of parts of the Richfield and Cedar City 1 $\times 2$ degree quadrangles, Utah: U.S. Geological Survey Open-File Report 72-387, scale 1:250,000.

U.S. GEOLOGICAL SURVEY, 1976, Environmental analysis, prepared for 16 deep test wells in Roosevelt Hot Springs unit, Phillips Petroleum Company: U.S. Geological Survey Conservation Division, Office of the Area Geothermal Supervisor, Environmental Assessment, no. 33, $210 \mathrm{p}$.

U.S. GEOLOGICAL SURVEY, 1977, Environmental analysis prepared for geothermal leases U-28947, U-28948, U-29215A, Phillips Petroleum Company; and U-29553 through U-29558, Union Oil Company, Cove FortSulphurdale KGRA, Utah: U.S. Geological Survey Conservation Division, Office of the Area Geothermal Supervisor, Menlo Park, California, $306 \mathrm{p}$.

U.S. GEOLOGICAL SURVEY, 1979a, Aeromagnetic map of the Adamsville and Minersville area, Utah: U.S. Geological Survey Open-File Report 79-1684, scale 1:62,500.

U.S. GEOLOGICAL SURVEY, 1979b, Aeromagnetic map of the Richfield area, Utah: U.S. Geological Survey Open-File Report 79-1367, scale 1:62,500.

U.S. GEOLOGICAL SURVEY, 1979c, Radium and uranium in mineral springs (abs.), in Geological Survey research 1979, 1980: U.S. Geological Survey Professional Paper 1150, p. 48.

U.S. GEOLOGICAL SURVEY, 1983a, Geothermal resources - GEOTHERM, in Scientific and technical, spatial, and bibliographic data bases and systems of the U.S. Geological Survey, 1983: U.S. Geological Survey Circular 817, p. 2-61 - 2-63.

U.S. GEOLOGICAL SURVEY, 1983b, United States terrestrial heat flow, in Scientific and technical, spatial, and bibliographic data bases and systems of the U.S. Geological Survey, 1983: U.S. Geological Survey Circular 817, p. 2-139 - 2-140.

UTAH DEPARTMENT OF NATURAL RESOURCES, 1976, Utah energy resource data: Utah Department of Natural Resources, $27 \mathrm{p}$.

UTAH ENERGY OFFICE, 1981, Resource assessment report Crystal Hot Springs geothermal area: Utah Energy Office Report, no. DOE/ET 27027-4, 108 p.

Adaptability of Utah State Prison facility to geothermal heating; structure and geology of Crystal Hot Springs area; maximum temperature of waters; existing heating design and proposed design; environmental impact studies; aeromagnetic survey results; subsurface interpretations of gravity survey; basis for selection of test hole sites; procedures for drilling holes SF-1 and USP/TH-1; results and interpretations of both holes; monitoring of Crystal Hot Springs for determination of baseline thermal, hydraulic, and chemical characteristics; tables showing results of chemical monitoring; program to aid in siting and design of proposed production well; table 
showing noncondensable gas data for Utah Roses Production well; artesian flow test procedures and results; production potential; alternatives for disposal of spent fluids.

UTAH GEOLOGICAL AND MINERAL SURVEY, 1978, Crystal Hot Lakes provide geothermal energy at Pointof-the-Mountain: Utah Geological and Mineral Survey, Survey Notes, v. 12 , no. 4 , p. 6.

Early history of Crystal Hot Lakes prior to present testing for geothermal resources.

UTAH GEOLOGICAL AND MINERAL SURVEY, compilers, 1980, Geothermal Resources of Utah, 1980: Map prepared by the National Oceanic and Atmospheric Administration for the U.S. Department of Energy, scale 1:500,000.

Map showing low-temperature geothermal waters of Utah, thermal springs and wells, known geothermal resource areas, heat flow measurements, temperatures, total dissolved solid concentrations, flow rates and depth of wells, topography, major physiographic provinces, Indian and military reservations, national and state forests, national parks, monuments, wilderness areas, population centers, and highway systems; attached table of thermal springs and wells organized by county.

UTAH GEOLOGICAL AND MINERAL SURVEY, 1981, Central Wasatch geology, 1981; dam safety, seismotectonics, engineering geology, geothermal prospects, mine development; illustrated road logs with abstracts (abs.): Utah Geological Association Publication 9, 46 p.

UTAH GEOLOGICAL AND MINERAL SURVEY, compilers, 1983, Energy resources map of Utah: Utah Geological and Mineral Survey Map 68, scale 1:500,000.

UTAH ROSES, INCORPORATED, 1978, Floral greenhouse industry geothermal energy demonstration project: Utah Roses Technical Proposal Report, no. UR-G-78, v. 1, 48 p.

WAGSTAFF, Ward, 1982, Heat pump system for the LDS Church Office Building: Geothermal Resources Council Bulletin, v. 11, no. 11, p. 15-18.

Description of structure of the 28 story Church of Jesus Christ of Latter-Day Saints Office Building; groundwater heat-pump system in the building; pumps used; four wells into alluvium below building; production rates and temperature ranges of well; methods used to balance heating and cooling loads for the building; methods of operation of the building's two ventilation systems, the primary induction system, and the high velocity dual-duct system; operation efficiencies and problems; estimated heating and cooling load of 4135 million BTUs; electrical cost estimates.

WALKER, B. A., and Entingh, D. J., 1981, Status of U.S. direct utilization of geothermal energy: Geothermal Resources Council, Transactions, v. 5, p. 579-582.
WANNAMAKER, P. E., 1978, Magnetotelluric investigations at the Roosevelt Hot Springs KGRA and Mineral Mountains, Utah: University of Utah Department of Geology and Geophysics Topical Report, no. 78-1701.a.6.1, 54 p.

Purpose of study; interpretation of the magnetotelluric soundings; two-dimensional model studies and three. dimensional implications.

WANNAMAKER, P. E., 1983, Resistivity structure of the northern Basin and Range, in The role of heat in the development of energy and mineral resources in the northern Basin and Range Province: Geothermal Resources Council Special Report 13, p. 345-362.

WANNAMAKER, P. E., and Hohmann, G. W., 1980, Regional resistivity structure at the Roosevelt Hot Springs, Utah, KGRA from magnetotellurics; theoretical 3-D model studies (abs.): EOS Transactions, American Geophysical Union, v. 61, no. 17 , p. 226.

Purpose of study; simulated effects of trends; regional distortion of electric field and effect on transverse electric interpretations.

WANNAMAKER, P. E., Hohmann, G. W., Sill, W. R., and Ward, S. H., 1979, Two- and three-dimensional magnetotelluric modeling with applications to crustal structure and reservoir assessment at the Roosevelt Hot Springs KGRA, Utah (abs.): Society of Exploration Geophysics Abstract, no. 49, p. 104.

Travel time delays beneath geothermal area; inversion modeling to obtain a three-dimensional model.

WANNAMAKER, P. E., Sill, W. R., Ward, S. H., and Combs, J., 1978, Magnetotelluric observations at the Roosevelt Hot Springs KGRA and Mineral Mountains, Utah: Geothermal Resources Council, Transactions, v. 2, sec. 2, p. 697-700.

See Wannamaker (1978).

WANNAMAKER, P. E., Ward, S. H., Hohmann, G. W., and Sill, W. R., 1980, Magnetotelluric models of the Roosevelt Hot Springs thermal area, Utah: Earth Science Laboratory/University of Utah Research Institute Report, no. DOE/ET/27002-8, 213 p.

Magnetotelluric theory for three-dimensional bodies in layered earths; utility of one- and two-dimensional algorithms for interpreting three-dimensional geology; magnetotelluric theory includes electromagnetic field relations, tensor magnetotelluric quantities, and coupled body theory; three-dimensional magnetotelluric model includes responses of small scale structures and sedimentary basins; appendix of numerical tests of coupled body approximation.

WANNAMAKER, P. E., Ward, S. H., Hohmann, G. W., and Sill, W. R., 1983, Deep resistivity structure in southwestern Utah and its geothermal significance: Earth Science Laboratory/University of Utah Research Institute Report, no. DOE/ID/12079-89, 96 p. 
Purpose of study; tectonic setting of eastern Great Basin and adjacent regions; seismicity, volcanism, heat flow, gravity, and magnetics of area; upper and middle crustal, deep crustal, and upper mantle resistivity mechanisms; previous resistivity studies in the eastern Great Basin including a 1977 multifrequency dipole-dipole galvanic resistivity survey at Roosevelt Hot Springs; 93 tensor magnetotelluric stations recorded near Roosevelt; problems of upper crustal lateral inhomogeneities of area; map of magnetotelluric site locations; observed apparent resistivity and impedance phase pseudosections of area; calculated pseudosections and model resistivity cross sections; graph showing best-fit regional resistivity profile for the area; deep resistivity profile beneath Roosevelt; controls on geothermal resources in southwestern Utah; conclusions.

WARD, R. W., 1979, Seismologists seeking heat: Geotimes, v. 24, no. 8, p. 21-24.

WARD, S. H., 1975, Seeking geothermal resources: Geotimes, v. 20 , no. 11 , p. 14-15.

WARD, S. H., 1977, Geothermal exploration architecture: ERDA Technical Report, v. 77-2, 19 p.

WARD, S. H., 1978, Program review: resource evaluation, reservoir confirmation, and exploration technology: University of Utah Department of Geology and Geophysics Technical Report, no. 78-1701.b.5.1, unpaginated.

WARD, S. H., 1983a, Controlled source electromagnetic methods in geothermal exploration: Earth Science Laboratory/University of Utah Research Institute Report, no. DOE/ID/12079-97, $46 \mathrm{p}$.

Objective of study; previous studies of electromagnetic methods for geothermal exploration; applications of controlled source electrical methods; problems with inductive CSEM systems including natural field noise, cultural noise, and geological noise due to overburden and resolution; effects of geological noise, topography, current channeling, depth of exploration, and lack of interpretational aids; graph showing generalized spectrum of natural magnetic fields; basis for selecting inductive electromagnetic systems; map of first separation dipole-dipole resistivity of the Roosevelt Hot Springs KGRA; CSAMT apparent resistivity maps of Roosevelt Hot Springs KGRA at frequencies of 98 and $977 \mathrm{~Hz}$; graphs showing TM mode CSAMT field and modeled data from Roosevelt Hot Springs; graph showing twodimensional model from which modeled data were calculated; other CSEM field examples.

WARD, S. H., 1983b, Geophysical studies of active geothermal systems in the northern Basin and Range, in The role of heat in the development of energy and mineral resources in the northern Basin and Range Province: Geothermal Resources Council Special Report 13, p. 121-158; also, 1984, Earth Science Laboratory/University of Utah Research Institute Report, no. DOE/ID/12079-108, $37 \mathrm{p}$.
Objectives of study; distribution of known hightemperature resources in the Basin and Range; methods of geophysical exploration; problems with geophysical methods in geothermal applications; table comparing values of Poisson's ratio for Roosevelt Hot Springs with other geothermal systems; brief reports on geology and geophysics of several known geothermal resource areas; map showing geology of Roosevelt Hot Springs KGRA and vicinity; alteration and mineral assemblages of the Roosevelt system; thermal studies map of Roosevelt; map showing first separation resistivity from $300 \mathrm{~m}$ dipole-dipole survey; map of the CSMAT $32 \mathrm{~Hz}$ apparent resistivity; self-potential map and map showing microearthquakes occurring during July 1981 swarm at Roosevelt; Wadati diagram derived from earthquakes occurring during July 1981 swarm; evaluation of the contribution made by each of 14 methods used to understand reservoirs at each of 13 geothermal projects in the Basin and Range.

WARD, S. H., Bodell, J. M., Brumbaugh, W. D., Carter, J. A., Cook, K. L., Crebs, T. J., Olsen, T. L., Parry, W. T., Sill, W. R., Smith, R. B., Thangsuphanich, I., and Tripp, A. C., 1977, Part II - Geophysics of the Roosevelt Hot Springs thermal area, Utah: Earth Science Laboratory/University of Utah Research Institute Report, no. 77-2, $17 \mathrm{p}$.

Microearthquake monitoring to study correlation of seismicity to known geothermal features; gravity anomaly map and interpretation; total magnetic intensity anomaly map and interpretation; cross sections of gravity anomalies and geologic structure; shallow geothermal gradient map and interpretation.

WARD, S. H., Bowman, J. R., Cook, K. L., Parry, W. T., Nash, W. P., Smith, R. B., Sill, W. R., and Whelan, J. A., 1978, Geology, geochemistry, and geophysics of the Roosevelt Hot Springs thermal area, Utah - a summary: Brigham Young University Geology Studies, v. 25, pt. $1,71 \mathrm{p}$.

Geology, seismic activity, and sources of anomalous heat flow at Roosevelt; surface alteration deposits from the thermal springs.

WARD, S. H., Cook, K. L., Nash, W. P., Parry, W. T., Peeples, W. J., Sill, W. R., Smith, R. B., Brown, F. H., and Whelan, J. A., 1974, Systems of geothermal exploration with applications in Utah: University of Utah, Department of Geology and Geophysics Summary Progress Report Grant, no. NSF GI-43741, 9 p.

Over $99 \mathrm{~km}$ of traverse line surveyed on a dipole-dipole resistivity survey at Roosevelt Hot Springs; 50 electromagnetic soundings and 10 Schlumberger vertical electric soundings; seven weeks of microearthquake monitoring at Roosevelt Hot Springs and Cove FortSulphurdale; regional gravity surveys from Roosevelt Hot Springs and central Mineral Mountains, southern Mineral Mountains, and Cove Fort area and northern Mineral Mountains; reduction of gravity data; interpre- 
tation of gravity data; aeromagnetic survey over the Mineral Range and Cove Fort-Sulphurdale; igneous petrology of Mineral Range and vicinity; paleomagnetic studies and results; brief discussion of geochemistry of Utah geothermal systems; list of consultants used in study.

WARD, S. H., Cook, K. L., Parry, W. T., Peeples, W. J., Nash, W. P., Smith, R. B., and Whelan, J. A., 1974, Integrated exploration in geothermal area (abs.): Geological Society of America Abstracts with Programs, v. 6, no. 3, p. 272-273.

WARD, S. H., Glenn, W. E., Smith, B. D., and Rijo, L., 1975 , Electromagnetic soundings in the geothermal environment (abs.), in Society of Exploration Geophysicists, 44th Annual International Meeting: Geophysics, v. 40 , no. 1 , p. 177 .

WARD, S. H., Nash, W. P., Parry, W. T., Peeples, W. J., Sill, W. R., Smith, R. B., and Whelan, J. A., 1974, Systems of geothermal exploration with applications in Utah: University of Utah Department of Geology and Geophysics Project Definition Report Grant, no. NSF GI-43741, 39 p.

WARD, S. H., Parry, W. T., Nash, W. P., Sill, W. R., Cook, K. L., Smith, R. B., Chapman, D., Brown, F., Whelan, J., and Bowman, J., 1978, A summary of the geology, geochemistry, and geophysics of Roosevelt Hot Springs thermal area, Utah: Geophysics, v. 43, no. 7 , p. 1515-1542.

Geology, spring deposits and associated alteration, and water chemistry at Roosevelt Hot Springs; microearthquake monitoring; gravity and magnetic surveys; electrical and heat flow measurements; reservoir configuration and heat source; guidelines for exploration procedures at Roosevelt Hot Springs.

WARD, S. H., Rijo, L., and Petrick, W. E., 1975, Electromagnetic soundings in the geothermal environment (abs.): United Nations Symposium on the Development and Use of Geothermal Resources, Abstracts, no. 2., unpaginated.

WARD, S. H., Ross, H. P., and Nielson, D. L., 1979, A strategy of exploration for high-temperature hydrothermal systems in the Basin and Range Province: Earth Science Laboratory/University of Utah Research Institute Report, no. DOE/ET/27002-5, 46 p.

See Ward and others (1981).

WARD, S. H., Ross, H. P., and Nielson, D. L., 1980, Strategy of exploration for high-temperature hydrothermal systems in Basin and Range Province (abs.): American Association of Petroleum Geologists Bulletin, v. 64, no. 5 , p. 799 .

See Ward and others (1981).

WARD, S. H., Ross, H. P., and Nielson, D. L., 1981, Exploration strategy for high-temperature hydrothermal systems in Basin and Range Province: American Associ- ation of Petroleum Geologists Bulletin, v. 65, no. 1, p. 86-102.

Generalized model of a convective hydrothermal system; geologic cross sections of Roosevelt Hot Springs and Cove Fort-Sulphurdale KGRAs; summary of previous geothermal exploration studies in the Basin and Range; evaluation of the usefulness of geologic mapping, hydrology, gravity, ground magnetics, aeromagnetics, magnetotellurics, electrical resistivity, self-potential, passive seismic, reflection seismic, and thermal methods for geothermal exploration; table showing regional applicability of exploration/assessment techniques; proposed exploration strategies including literature and data search, chemical and isotopic analyses of water, mapping, thermal gradient measurements, conceptual modeling, hydrology, well logging, various geophysical and geochemical techniques, and reservoir modeling.

WARD, S. H., and Sill, W. R., 1976a, Dipole-dipole resistivity delineation of the near surface at the Roosevelt Hot Springs KGRA: University of Utah, Department of Geology and Geophysics Technical Report, v. 76-1, 10 p.; also, National Technical Information Service Report 264-89710, $52 \mathrm{p}$.

Purpose of survey; interpretations of resistivities plotted in pseudosection; maps of Roosevelt KGRA first separation resistivity dipole-dipole array and pseudosections.

WARD, S. H., and Sill, W. R., 1976b, Dipole-dipole resistivity surveys, Roosevelt Hot Springs KGRA: University of Utah, Department of Geology and Geophysics Final Report, v. 2, National Science Foundation Grant GI-43741, 29 p.

Dipole spacings used in survey; objective of survey; presentation of data; 1:24,000 scale fracture map; air photos, aeromagnetic map, and interpretive geology; alteration assemblages taken from drill hole data; hydrology and resistivity data; porosity and effects of clay alteration on resistivity; speculation on heat source; twodimensional transmission-surface forward algorithm used to model observed data; results of modeling; onedimensional resistivity, temperature, salinity, and porosity modeling; comparison of bipole-dipole and dipole-dipole resistivity techniques; conclusions and recommendations.

WARD, S. H., and Sill, W. R., 1984, Resistivity, induced polarization and self-potential methods in geothermal exploration: Earth Science Laboratory/University of Utah Research Institute Report, no. DOE/ID/12079-90, $100 \mathrm{p}$.

WARING, G. A., 1951, Summary of literature on thermal springs: International Union Geodetics, Geophysics, Association of International Hydrologists Scientific Assembly, General, Bruxelles, 1951, Proceedings, v. 2, p. 289-293.

WARING, G. A., 1952, Summary of literature on thermal springs: International Association Science Hydrologists Assembly General, Bruxelles, 1951, T. 2, p. 288-292. 
WARING, G. A., 1953, The occurrence and distribution of thermal springs: Pacific Scientific Association, 7th Congress, New Zealand, 1949, Proceedings, v. 2, p. 439-448.

WARING, G. A., (revised by R. R. Blankenship and R. Bentall), 1965, Thermal springs of the United States and other countries of the world - a summary: U.S. Geological Survey Professional Paper 492, 383 p.; also, (abs.) Geoscience Abstracts, v. 7, no. 12, p. 75 (7-7174).

WECHSLER, D. J., and Smith, R. B., 1979, An evaluation of hypocenter location techniques with applications to southern Utah, regional earthquake distributions and seismicity of geothermal areas: University of Utah, Department of Geology and Geophysics Report, no. 78-28392.a.12, 131 p.

WENDER, L. E., 1976, Chemical and mineralogical evolution of the Cenozoic volcanics of the Marysvale, Utah area: Salt Lake City, Utah, University of Utah, unpublished Masters thesis, 57 p.

WENDER, L. E., and Nash, W. P., 1976, Chemistry and mineralogy of the Cenozoic volcanic rocks of the Marysvale area, Utah (abs.): Geological Society of America Abstracts with Programs, v. 8, no. 6, p. 1163-1164.

WENDER, L. E., and Nash, W. P., 1979, Petrology of Oligocene and early Miocene calc-alkalic volcanism in the Marysvale area, Utah: Geological Society of America Bulletin, v. 90, no. 1, pt. II, p. 34-76.

WHELAN, J. A., 1970, Radioactive and isotopic age determinations of Utah rocks: Utah Geological and Mineral Survey Bulletin 81, 75 p.

WHELAN, J. A., 1976, Geothermal gradient data, Cedar City 1X2 degree quadrangle: Utah Geological and Mineral Survey Map, no. 40, scale 1:250,000.

WHELAN, J. A., 1977, Thermal gradient and heat flow drilling: University of Utah, Department of Geology and Geophysics Final Report, v. 5, contract no. GI-43741, $48 \mathrm{p}$.

WHELAN, J. A., and Petersen, C. A., 1974, Bonneville Salt Flats - a possible geothermal area?: Utah Geological and Mineral Survey, Utah Geology, v. 1, no. 1, p. 71-82; also, 1973, Utah Geological and Mineral Survey OpenFile Report, no. 14, 11 p.

Unusually high geotherrinal gradients from Bonneville Salt Flats noted in prior studies; depths, locations, specific capacities, and total dissolved solids for 13 deep brine wells; 27 brackish water well depths and two well transmissivities; brackish water sources; temperatures from two fault line springs; structural geology and stratigraphy of the Salt Flats; stratigraphy, structure, petrography, and volcanic history of the Silver Island Range; geothermal reservoir temperature estimates; land and well ownership; conclusions and recommendations.
WHITE, D. E., 1938, Fumaroles, hot springs, and hydrothermal alteration: American Geophysical Union, Transactions, v. 44, no. 2, p. 508-511.

WHITE, D. E., 1955, Thermal springs and epithermal ore deposits: Economic Geology, Fiftieth Anniversary Volume, p. 100-154.

WHITE, D. E., 1963, Summary of studies of thermal waters and volcanic emanations of the Pacific region, 1920-1961, in Geology and solid earth geophysics of the Pacific basin: Pacific Scientific Association, 10th Congress, Honolulu, 1961, p. 161-169.

WHITE, D. E., and Heropoulos, C., 1983, Active and fossil hydrothermal convection systems of the Great Basin, in The role of heat in the development of energy and mineral resources in the northern Basin and Range Province: Geothermal Resources Council Special Report 13, p. 41-54.

WHITE, D. H., Mathews, H. B., Wolf, D., and Young, T. L., 1982, Advancements in the utilization of geothermal energy in western USA: Institution of Chemical Engineers Symposium Series (England), v. 78, p. T6/27-T6/41.

WHITE, I. L., and others, 1979a, Energy from the west; energy resource development systems report, Volume I. Introduction and general social controls, in Seamalert: National Technical Information Service PB-299 $177 / 6 \mathrm{GA}$, or as a set of 6 reports NTIS 299-176-SET, $181 \mathrm{p}$.

WHITE, I. L., and others, 1979b, Energy from the west; energy resource development systems report, Volume VI. Geothermal: National Technical Information Service Report PB-299 182/6ST, 221 p.

WHITE, I. L., and others, 1979c, Energy from the west; impact analysis report, Volume I. Introduction and summary: U.S. Environmental Protection Agency Report, no. EPA-600/7-79-082A, 159 p.

WHITE, K. L., 1980, Potential pollutants of geothermal energy and geothermal development in Utah, in Rom, W. N., and Archer, V. E., Health implications of new energy technologies: Health Implications of the New Energy Technologies Conference, Ann Arbor Science Publishers, Incorporated, Michigan, p. 553-564.

WHITE, K. L., Hill, A. C., and Ursenbach, W. O., 1978, Environmental overview report on Utah geothermal resource areas, Roosevelt Hot Springs, Cove FortSulphurdale, Thermo Hot Springs-Lund KGRAs: University of Utah Research Institute/Environmental Studies Laboratory Report, no. UCRL-13955, v. 1, 9.47 p.

WILLIS, C. P., 1980, Radium and uranium determination in samples of Utah Roses geothermal water: National Technical Information Service Report, no. EGGPHYS-5169, 11 p.

Analysis of Utah Roses geothermal well waters for uranium and radium by direct alpha counting on separated 
elements; tables of uranium and radium fractions; appendix of chemical and radiochemical procedures used in study.

WILSON, W. R., 1980, Thermal studies in a geothermal area: Salt Lake City, Utah, University of Utah, unpublished Ph.D. thesis, 145 p.

Purpose of study; map of location and general geology of Roosevelt Hot Springs; methods used to measure temperatures in 53 drill holes in study area; graphs of temperature-depth curves; procedures for determining thermal conductivity and histogram of results; thermal conductivity values for major geologic units; heat transfer characteristics; plot showing magnitude of conductive lateral heat transfer; map showing surface conductive heat flow for area; map of downward continuation of the surface heat flow; appendix showing downward continuation formulas; graph of two-dimensional power spectrum of gridded surface heat flow; appendix of temperature-depth curves for Roosevelt Hot Springs; shallow heat flow surveys across normal fault geothermal systems providing fault geometry and fluid flow information; temperature-depth results from five drill holes at the Monroe KGRA; investigation of heat flow data for geometric properties of the Monroe geothermal system; datum correction for heat flow measurements made on an arbitrary surface.

WILSON, W. R., and Chapman, D. S., 1978, Interpretation of heat flow results at Roosevelt Hot Springs, Utah (abs.): EOS Transactions, American Geophysics Union, v. 59 , no. 12 , p. 1201 .

Use of 47 drill holes to determine temperature gradients and thermal conductivity of lithologic units; configuration of near surface hydrothermal system; downward continuation model.

WILSON, W. R., and Chapman, D. S., 1979, Heat flow mapping at Roosevelt Hot Springs, Utah as a geothermal exploration method (abs.): Geophysics, v. 44 , no. 3 , p. 405.

Use of drill holes to obtain thermal conductivity measurements of lithologic units; conductive heat flow calculated for upper 30 meters of holes; heat flow pattern; downward continuation model.

WILSON, W. R., and Chapman, D. S., 1980, Three topical reports: I. Thermal studies at Roosevelt Hot Springs, Utah; II. Heat flow above an arbitrarily dipping plane of heat sources; III. A datum correction for heat flow measurements made on an arbitrary surface: Earth Science Laboratory/University of Utah Research Institute Report, no. DOE/ID/12079-19, 144 p.

Part I. Use of thermal gradient, thermal conductivity measurements, and heat flow determinations from 53 drill holes for geometry and temperature of the geothermal system; heat transfer characteristics in the geothermal system; assessment of factors that cause non-linear temperature profiles; appendices of temperature-depth curves at Roosevelt and formulae for downward continuation of surface heat flow map. Part II. Use of shallow heat flow surveys across faults in geothermal system to provide information on fault geometry and fluid flow; two-dimensional model of fault zone as a plane of heat source embedded in a conductive medium; geometric parameter estimates using inversion theory; uses Monroe geothermal system for testing model. Part III. Adjusts heat flow measurements to a constant datum level; potential field theory and numerical techniques; use of three test models to determine accuracy of numerical approximation; correction of heat flow anomaly at Roosevelt Hot Springs.

WOODWARD, L. A., 1970, Tectonic implications of structures of Beaver and northern San Francisco Mountains, Utah: Geological Society of America Bulletin, v. 81, no. 5, p. 1577-1584.

WRIGHT, P. M., 1966, Geothermal gradient and regional heat flow in Utah: Salt Lake City, Utah, University of Utah, unpublished Ph.D. thesis, $181 \mathrm{p}$.

WRIGHT, P. M., Foley, D., Nichols, C. R., and Grim, P. J., 1978, Western states cooperative direct heat geothermal program of DOE: Geothermal Resources Council, Transactions, v. 2, p 739-742.

YOUNG, C. Y., Ward, R. W., and Lin, T. L., 1979, Seismic attenuation observations across Roosevelt Hot Springs, KGRA (abs.): EOS Transactions, American Geophysical Union, v. 60 , no. 46 , p. 946.

Program design for mapping traveltime delays beneath geothermal areas; procedures used to digitize the seismographs of 41 teleseisms for quantitative attenuation analysis; inversion technique used to obtain threedimensional $Q$ mode for the region.

YOUNG, R. A., and Carpenter, C. H., 1965, Ground-water conditions and storage in the central Sevier Valley, Utah: U.S. Geological Survey Water-Supply Paper, no. $1787,95 \mathrm{p}$.

YUSAS, M. R., 1979a, Stress history of the Mineral Mountains pluton, southwestern Utah (abs.): Geological Society of America Abstracts with Programs, v. 11, no. 6, p. 306.

YUSAS, M. R., 1979b, Structural evolution of the Roosevelt Hot Springs geothermal reservoir: Salt Lake City, Utah, University of Utah, unpublished Masters thesis, $120 \mathrm{p}$.

Purpose of study; map showing general geology of the Mineral Mountains area; geology and tectonic setting of the Mineral Mountains; procedures used in mapping structure; analysis of structure and fracture systems; table showing tensile strengths of rocks; development of fracture permeability; procedures used in strain relief measurements; orientations and magnitudes of principal strains; table showing results of strain relief measurements; depth of producing geothermal reservoirs; formation of the geothermal reservoir; appendices showing 
unreduced strain relief test results and results of uniaxial compression tests.

YUSAS, M. R., and Bruhn, R. L., 1979, Structural fabric and in-situ stress analyses of the Roosevelt Hot Springs KGRA: University of Utah, Department of Geology and Geophysics, Report, no. DOE/ET/28392-31, 62 p.

Geometry and origin of fractures used to develop a structural model of the geothermal reservoir at the Roosevelt KGRA; geologic and tectonic setting; field mapping and structural analysis of joints, dikes, and shear zones; genesis and development of fracture permeability in the geothermal reservoir; measurement of strain relief to determine active and residual stresses; possible mechanisms of strain relief.

ZANDT, G. M., McPherson, L., Schaff, S., and Olsen, S., 1982, Seismic baseline and induction studies: Roosevelt Hot Springs, Utah and Raft River, Idaho: Earth Science Laboratory/University of Utah Research Institute Report, no. DOE/ID/01821-T1, 58 p.

Analytical procedures; geographic orientation of Raft River and Roosevelt KGRAs in the Intermountain Seismic Belt; background seismicity; microearthquake swarm detected in the Mineral Mountains; techniques for locating hypocenters; geological interpretation of data; conclusions of microearthquake information; equipment used and logistics involved in study at Roosevelt; appendix describing method used for calibration of induced-seismicity network at Roosevelt.

ZIETZ, Isidore, Shuey, R., and Kirby, J. R., Jr., 1976, Aeromagnetic map of Utah: U.S. Geological Survey Geophysical Investigations Map GP-907, scale $1: 1,000,000$.

ZIMMERMAN, J. T., 1961, Geology of the Cove Creek area, Millard and Beaver Counties, Utah: Salt Lake City, Utah, University of Utah, unpublished Masters thesis, $91 \mathrm{p}$.

ZOBACK, M. L., and Anderson, R. E., 1983, Style of basin-range faulting as inferred from seismic reflection data in the Great Basin, Nevada and Utah, in The role of heat in the development of energy and mineral resources in the northern Basin and Range Province: Geothermal Resources Council Special Report 13, p. 363-382.

ZOHDY, A. A. R., and Bisdorf, R. J., 1976, Schlumberger soundings in the upper Raft River and Raft River Valleys, Idaho and Utah: U.S. Geological Survey Open-File Report 76-92, 77 p. 


\title{
GOVERNMENT-FUNDED GEOTHERMAL PROJECTS AND GEOTHERMAL DEVELOPMENTS IN UTAH
}

\author{
NATIONAL STUDIES
}

In addition to Utah specific projects, several U.S. Geological Survey national and regional geothermal projects have involved significant investigations in Utah. Although these studies were not Utah specific, parts of the studies involved field work in Utah and the reports have contributed significantly to understanding the geothermal systems in the state.

National projects include work used to develop the Assessment of Geothermal Resources of the United States - 1975, White, D. E., and Williams, D. L., editors, (see listings: Diment and others, 1975; Nathenson and Muffler, 1975; Renner and others, 1975; Smith and Shaw, 1975), Assessment of Geothermal Resources of the United States - 1978, Muffler, L. J. P., editor, (see listings: Brook and others, 1979; Sammel, 1979; Sass and Lachenbruch, 1979; Smith and Shaw, 1979), and Assessment of Low-Temperature Geothermal Resources of the United States - 1982, Reed, M. J., editor (see listings: Mariner, Brook, and others, 1983; Nathenson and others, 1983).

Significant work was also done as part of the evaluation of Known Geothermal Resource Areas (KGRAs) in Utah. The results of some of this work were published and are included in the reference list; however, some of the work did not result in publications.

\section{STATEWIDE STUDIES}

AREA:

FUNDING:

DATE:

TITLE:

PRINCIPAL INVESTIGATOR: SUMMARY:

\section{REFERENCES:}

AREA:

FUNDING:

DATE:

TITLE: PRINCIPAL INVESTIGATOR SUMMARY:

\section{REFERENCES:}

AREA:

FUNDING:

DATE:

TITLE:

PRINCIPAL INVESTIGATORS: SUMMARY:

\section{REFERENCE:}

AREA:

FUNDING:

DATE:

TITLE:

PRINCIPAL INVESTIGATOR: SUMMARY:

REFERENCE:
Northern and central Wasatch Front, Great Salt Lake area, and south-central Utah Department of Energy and National Science Foundation 1981-1983

Isotopic and Ion Chemistry of Thermal Waters

Cole, D. R., Earth Science Laboratory/University of Utah Research Institute

The reports analyze major cations and anions, and oxygen and hydrogen isotopes from thermal springs associated with normal faults. Cole studied geothermometer temperatures, mineral saturation trends for thermal waters, mineral-fluid equilibria, origin of springs, and determined ages of Red Hill and Thermo waters.

Cole, 1981, 1982, 1983

\section{Utah}

Department of Energy

1977-1983

Utah GEOTHERM Data Base

Murphy, P. J., Utah Geological and Mineral Survey

Chemical data on Utah hot springs were entered in the U.S. Geological Survey computer file GEOTHERM, an information system that maintained data files on the geology, geochemistry, and hydrology of U.S. geothermal sites until 1983.

Bliss, 1983; Swanson, 1977; Teshin and others, 1979; U.S. Geological Survey, 1983b

\section{Utah}

Department of Energy

1978

Thermal Waters of Utah

Goode, H. D., Utah Geological and Mineral Survey

Regions yielding slightly warm, warm, or hot water are discussed. The report includes records of 1500 wells and springs with temperatures greater than $16^{\circ} \mathrm{C}$.

Goode, 1978

\section{Utah}

Department of Energy

1980

Geothermal Resources of Utah (map)

Murphy, P. J., Utah Geological and Mineral Survey

The map identifies 327 thermal wells and springs, water chemistry and temperature, heat flow measurements, and the locations of nine KGRAs.

Utah Geological and Mineral Survey, compilers, 1980 
AREA:

FUNDING:

DATE:

TITLE:

PRINCIPAL INVESTIGATOR:

SUMMARY:

\section{REFERENCE:}

AREA:

FUNDING:

DATE:

TITLE:

PRINCIPAL INVESTIGATORS: SUMMARY:

REFERENCES:

AREA:

FUNDING:

DATE:

TITLE:

PRINCIPAL INVESTIGATOR:

SUMMARY:

\section{REFERENCES:}

AREA:

FUNDING:

DATE:

TITLE:

PRINCIPAL INVESTIGATOR:

SUMMARY:

REFERENCES:

AREA:

FUNDING:

DATE:

TITLE:

PRINCIPAL INVESTIGATOR:

SUMMARY:

\section{REFERENCE:}

AREA:

FUNDING:

DATE:

TITLE:

PRINCIPAL INVESTIGATOR:
Utah

Department of Energy

1984-1985

Annotated Geothermal Bibliography of Utah

Budding, K. E., Utah Geological and Mineral Survey

The bibliography contains approximately 750 references relating to geothermal resources of Utah. Those references which pertain directly to a resource are annotated. Accompanying the bibliography is a list and brief description of government funded geothermal projects and commercial geothermal developments.

this report

\section{Utah}

Department of Energy, Utah Division of Water Rights

1979-1982

Commercialization Planning Program

Green, Stanley, Water Rights; Hanny, J. A., Lunis, B. C., EG\&G Idaho, Incorporated

The program worked towards the development of geothermal resources in Utah. The reports cover the hydrothermal resources and geology, activities that lead to commercialization, plans for development, government assistance to Utah projects, energy use, and leasing and permitting policies.

Green and Wagstaff, 1979; Hanny and Lunis, 1979; Lunis and Toth, 1982

\section{Utah}

U.S. Geological Survey

1977-1983

Heat Flow

Chapman, D. S., University of Utah Department of Geology and Geophysics

Sixty-two new heat flow determinations for Utah were added to known values. The greatest concentration of values are in southwestern Utah where geothermal potential is the highest. The reports outline two broad areas that have anomalous heat flux and high geothermal potential and define the thermal signatures of the Basin and Range and Colorado Plateau provinces.

Blackwell, 1983; Blackwell and Chapman, 1977; Bodell, 1981; Chapman and others, 1978

\section{Utah}

U.S. Geological Survey

1977-1983

Reconnaissance of Hydrothermal Resources of Utah

Rush, F. E., U.S. Geological Survey

This is an investigation of several geothermal areas in western Utah using hydrologic, geologic, geochemical and geophysical techniques.

Rush, 1977, 1983

Utah

U.S. Geological Survey

1978

$\mathrm{Na}-\mathrm{K}-\mathrm{Ca}$ and Silica Temperature Estimates for Utah Spring and Well Waters

Parry, W. T., University of Utah Department of Geology and Geophysics

The study contains $\mathrm{Na}-\mathrm{K}-\mathrm{Ca}$ and silica temperatures for spring and well waters calculated from chemical analyses in the U.S. Geological Survey computer file. Dugway Valley, Goshen Valley, Pavant Valley, and Skull Valley were studied in detail. Effects of mixing and clay exchange on chemical thermometers were evaluated.

Parry and Cleary, 1978

Utah

U.S. Geological Survey, Utah Geological and Mineral Survey

1970

Major Thermal Springs of Utah

Mundorff, J. C., U.S. Geological Survey 
SUMMARY:

REFERENCE:

AREA:

FUNDING:

DATE:

TITLE:

PRINCIPAL INVESTIGATOR:

SUMMARY:

\section{REFERENCE:}

AREA:

COUNTY:

THERMAL AREA:

FUNDING:

DATE:

TITLE:

PRINCIPAL INVESTIGATOR: SUMMARY:

\section{REFERENCES:}

AREA:

COUNTIES:

THERMAL AREAS:

FUNDING

DATE:

TITLE:

PRINCIPAL INVESTIGATOR:

SUMMARY:

\section{REFERENCES:}

AREA:

COUNTIES:

THERMAL AREAS:

FUNDING:

DATE:

TITLE:

PRINCIPAL INVESTIGATORS:

SUMMARY:

\section{REFERENCES:}

AREA:

COUNTIES:

THERMAL AREAS:
This report details the work done on the thermal, chemical, and geologic characteristics of the major thermal springs of Utah.

Mundorff, 1970

Utah

Utah Geological and Mineral Survey

1966

Geothermal Power Potential of Utah

Heylum, E. B., Utah Geological and Mineral Survey

Six areas or belts of thermal springs in Utah are described. The report lists principal warm and hot springs, describes geology, temperature, and heat source, and includes some chemical analyses.

Heylmun, 1966

\section{REGIONAL STUDIES WITHIN UTAH}

Cache Valley

Cache

none

Department of Energy, Utah Geological and Mineral Survey

1982-1983

Low-temperature Geothermal Potential

de Vries, J. L., Utah State University Geology Department

The study defines three areas of low-temperature geothermal potential using previous hydrologic and geothermal studies, water chemistry, conductivity, geothermometers, and thermal gradients.

de Vries, 1982, 1983

\section{Cedar City and Richfield 1x2 degree quadrangles}

Iron, Washington, Garfield, Kane, Beaver, Sevier

Laverkin, Veyo, Roosevelt

National Science Foundation

1976-1977

Geothermal Gradient Study

Whelan, J. A., Utah Geological and Mineral Survey

Available data were used, primarily water well data, to produce a regional geothermal gradient map of the Cedar City quadrangle. The map includes hot spring locations with calculated minimum reservoir temperatures and cold springs with calcuiated equilibrium temperatures. Eight holes were drilled in Beaver and Sevier counties to determine heat flow, thermal gradient, geology, and alteration.

Whelan, 1976, 1977

\section{East Shore of Great Salt Lake}

Weber, Davis

Ogden, Hooper

Department of Energy, Utah Geological and Mineral Survey

1980-1984

Geothermal Potential of East Shore Area and Hill Air Force Base

Glenn, W. E., Earth Science Laboratory/University of Utah Research Institute; Murphy, P. J., Klauk, R. H., Utah Geological and Mineral Survey

An intensive study was done in Davis and Weber Counties to advance the use of geothermal resources, particularly at Hill AFB in Weber County. Techniques used include geologic mapping; modeling of ground water; mercury concentrations in soils; gravity and reflection seismic surveys; thermal gradient drilling and well log interpretation; chemical analyses of common ions, stable isotopes, trace elements, dissolved solids; and calculation of geothermometers of area hot springs.

Glenn, Chapman, and others, 1980; Klauk and Prawl, 1984

\section{Escalante Desert and part of Washington County}

Iron, Washington

Newcastle, Lund 
FUNDING:

DATE:

TITLE:

PRINCIPAL INVESTIGATORS:

SUMMARY:

\section{REFERENCES:}

AREA:

COUNTIES:

THERMAL AREA:

FUNDING:

DATE:

TITLE:

PRINCIPLE INVESTIGATOR:

SUMMARY:

\section{REFERENCES:}

AREA:

COUNTY:

THERMAL AREA:

FUNDING:

DATE:

TITLE:

PRINCIPAL INVESTIGATOR:

SUMMARY:

REFERENCES:

\author{
AREA: \\ COUNTY: \\ THERMAL AREAS: \\ FUNDING: \\ DATE: \\ TITLE: \\ PRINCIPAL INVESTIGATORS:
}

SUMMARY:

\section{REFERENCES:}

\author{
AREA: \\ COUNTY: \\ THERMAL AREAS: \\ FUNDING: \\ DATE: \\ TITLE: \\ PRINCIPAL INVESTIGATOR:
}

Department of Energy

1980-1981

Gravity Survey

Pe, Win, Green, R. T., University of Utah Department of Geology and Geophysics

Four hundred thirty-six new gravity stations in the southern part of the Escalante Desert were combined with 917 existing stations to help evaluate the geothermal resource potential of the Newcastle and Lund KGRAs. A gravity survey delineated faults probably serving as hot water conduits in the geothermal systems. A separate gravity survey of the southwestern part of Washington County was done and regional and local gravity features were interpreted.

Green, 1981; Green and Cook, 1980a, 1980b; Pe, 1980; Pe and Cook, 1980a, 1980b

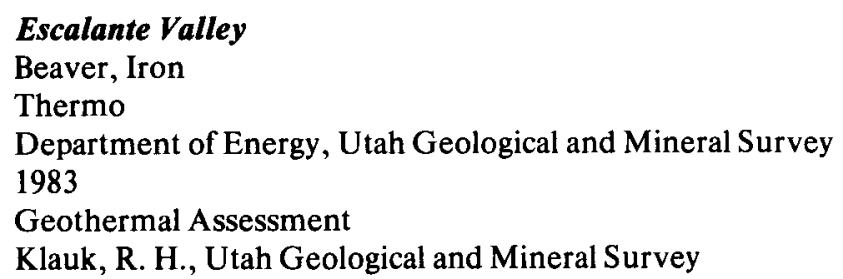
of the area for a possible missile experimental (MX) operations base using geology, water chemistry, temperature-depth measurements, geothermal gradients, and gravity data.

Klauk and Gourley, 1983a, 1983b

\section{Hansel and Curlew Valleys}

Box Elder

Coyote Spring

Department of Energy, Utah Geological and Mineral Survey

1984-1985

Low-temperature Geothermal Potential

Davis, M. C., Utah State University Geology Department

Two areas show potential for low-temperature geothermal resource development based on previous work, geology, geophysics, volcanic history, water sources and aquifers, water chemistry, and temperature surveys.

Davis, 1984; Davis and Kolesar, 1985

\section{Jordan Valley}

Salt Lake

Beck, Wasatch, Hobo, Clark

Department of Energy, Utah Geological and Mineral Survey

1981-1983

Gravity Study

Adhidjaja, J. I., University of Utah, Department of Geology and Geophysics; Meiiji Resource Consultants

A gravity survey, consisting of 800 gravity stations, was done to compliment two previous surveys at the Warm Springs fault and Crystal Hot Springs areas. A comple Bouguer gravity map was compiled by Adhidjaja. Gravity based interpretive bedrock geology was done by Meiiji.

Adhidjaja and others, 1981; Meiiji Resource Consultants, 1983

\author{
Jordan Valley \\ Salt Lake \\ Beck, Wasatch, Hobo, Clark \\ Department of Energy, Utah Geological and Mineral Survey \\ 1981-1984 \\ Low-temperature Geothermal Assessment \\ Klauk, R. H., Utah Geological and Mineral Survey
}


SUMMARY:

REFERENCES:

AREA:

COUNTIES:

THERMAL AREAS:

FUNDING:

DATE:

TITLE:

PRINCIPAL INVESTIGATORS:

SUMMARY:

\section{REFERENCES:}

AREA:

COUNTIES:

THERMAL AREAS:

FUNDING:

DATE:

TITLE:

PRINCIPAL INVESTIGATOR:

SUMMARY:

\section{REFERENCE:}

AREA:

COUNTIES:

THERMAL AREAS:

FUNDING:

DATE:

TITLE:

PRINCIPAL INVESTIGATOR:

SUMMARY:

REFERENCES:

AREA:

COUNTY:

THERMAL AREA:

FUNDING:

DATE:

TITLE:

PRINCIPAL INVESTIGATORS:

SUMMARY:
The reports include a geothermal assessment of the study area based on a temperature survey, chemical analysis of wells and springs, temperature depth measurements, and a gravity survey and subsequent modeling.

Klauk and Darling, 1984; Klauk and others, 1981

\section{Northern Wasatch Front}

Weber, Box Elder

Utah, Crystal (Madsen), Belmont (Udy), Little Mountain, Stinking, Bothwell, Cutler

Department of Energy, Utah Geological and Mineral Survey

1979-1984

Geothermal Investigation

Murphy, P. I., Klauk, R. H., Utah Geological and Mineral Survey

Four hot spring areas were investigated by studying the geologic structure of the Pleasant View salient, general geology, water chemistry and temperature. A valley-wide study identified three areas of low-temperature geothermal potential based on a temperature survey of 52 wells and springs, water chemistry, temperature versus depth measurements, geothermal gradients, and geothermometry for reservoir temperature calculations.

Klauk and Budding, 1984; Murphy and Gywnn, 1979b

\section{Part of southwestern and west-central Utah}

Juab, Millard, Sanpete, Sevier, Beaver, Piute, Iron

Abraham, Monroe-Red Hill, Joseph, Cove Fort, Roosevelt, Thermo, Newcastle

Department of Energy

1984-1985

High-temperature Geothermal Resources

Mabey, D. R., Utah Geological and Mineral Survey

An assessment of the high-temperature resources of Utah with emphasis on the region of the seven high-temperature geothermal systems in southwestern and west-central Utah. The study was based on existing geological, geophysical, and geochemical data with emphasis on the relationships of geothermal resources to Cenozoic igneous systems and tectonic events. Particular attention was given to the Cove Fort area. The final report includes resource assessments and discusses exploration strategies for possible undiscovered systems.

Mabey, D. R., and Budding, K. E., in review, High-temperature geothermal resources of Utah: Utah Geological and Mineral Survey Special Studies.

\section{Part of west-central Utah}

Juab, Sevier, Millard, Beaver

Abraham, Monroe-Red Hill, Cove Fort, Roosevelt

National Science Foundation

1974-1976

Geochemistry and Hydrothermal Alteration at selected Utah Hot Springs

Parry, W. T., University of Utah Department of Geology and Geophysics

The study analyzes the temperature and geochemistry of the springs, mixing models, geology, and alteration on the surface and at depth. Seismic, gravity, and aeromagnetic surveys were done in the Roosevelt Hot Springs and Cove Fort area.

Parry and others, 1976; Ward, Cook, Nash, and others, 1974

\section{Twin Peaks, Black Rock Desert}

Millard

Coyote Spring

Department of Energy, U.S. Geological Survey

1979-1984

Geology and Geophysics

Crecraft, H. R., Carrier, D. L., Serpa L. F., University of Utah Department of Geology and Geophysics

The study discusses the petrology, geochronology, and chemical evolution of the Twin Peaks rhyolite domes. It includes a geologic map, oxygen and hydrogen isotope studies, gravity and thermal studies, and aeromagnetics of Twin Peaks and the Black Rock Desert. 


\section{REFERENCES:}

AREA:

COUNTY:

THERMAL AREAS:

FUNDING:

DATE:

TITLE:

PRINCIPAL INVESTIGATOR:

SUMMARY:

\section{REFERENCES:}

AREA:

COUNTY:

THERMAL AREAS:

FUNDING:

DATE:

TITLE:

PRINCIPAL INVESTIGATOR:

SUMMARY:

REFERENCE:
Carrier, 1979; Carrier and Chapman, 1980; Crecraft, 1984; Crecraft and others, 1980b; Lynch and Nash, 1980; Nash, 1981; Serpa, 1980; Serpa and Cook 1979

\section{Utah and Goshen Valleys}

Utah

Saratoga, Crater, Goshen, Lincoln Point, Goose Point, Bird Island

Department of Energy, Utah Geological and Mineral Survey

1983-1984

Gravity Survey

Davis, D. A., University of Utah Department of Geology and Geophysics

The study includes the physiography of the area, general geology, and structural features. Gravity studies were undertaken to provide the structural framework needed to define geothermal targets by delineating faults, structural trends, intrusions, thickness of valley fill, and areas of increased host rock density. The gravity survey was conducted with 536 new stations and 563 stations from previous surveys. These studies substantiate fault control for most of the springs in Utah County.

Davis and Cook, 1983; Klauk and Davis, 1984

\section{Warm Springs Fault}

Salt Lake

Beck, Wasatch, Hobo, Clark

Department of Energy, Utah Geological and Mineral Survey

1979

Geothermal Investigation

Murphy, P. J., Utah Geological and Mineral Survey

The study looked at the geology and structure of the Warm Springs fault geothermal system, Hobo Springs fault, and the Salt Lake salient. It utilized a shallow ground temperature survey, temperature gradient holes, lithologic logs, water chemistry, and a gravity survey.

Murphy and Gwynn, 1979c

\section{LOCAL HOT SPRING OR THERMAL AREA STUDIES}

AREA:

FUNDING:

DATE:

TITLE:

PRINCIPAL INVESTIGATOR:

SUMMARY:

\section{REFERENCE:}

AREAS:

FUNDING:

DATE:

TITLE:

PRINCIPAL INVESTIGATOR: SUMMARY:

\section{REFERENCE:}

AREA:

FUNDING:

DATE:

TITLE:

PRINCIPAL INVESTIGATORS:

\section{Abraham (Crater)}

U.S. Geological Survey

1976

Audiomagnetotelluric Data Log

Senterfit, R. M., U.S. Geological Survey

The report includes a data log with a map of station locations, and two skin-depth pseudosections with telluric lines that run east-west and north-south.

Senterfit and Bedinger, 1976

\author{
Abraham (Crater), Joseph, Monroe-Red Hill, Thermo \\ U.S. Geological Survey \\ 1977 \\ Chemical, Isotopic, and Gas Compositions of Selected Thermal Springs in Arizona, \\ New Mexico, and Utah \\ Mariner, R. H., U.S. Geological Survey \\ Chemical analyses were done on water samples from Crater, Thermo, Monroe-Red \\ Hill, and Joseph KGRAs. Thermal aquifer temperatures were estimated, and the \\ composition of gases escaping from wells and springs was tested. \\ Mariner and others, 1977 \\ Cove Fort \\ Department of Energy \\ 1976-1979 \\ Resistivity and IP Surveys \\ Phoenix Geophysics; Ross, H. P., Earth Science Laboratory/University of Utah Re- \\ search Institute
}


SUMMARY:

\section{REFERENCES:}

AREA:

FUNDING:

DATE:

TITLE:

PRINCIPAL INVESTIGATOR: SUMMARY:

\section{REFERENCES:}

AREA:

FUNDING:

DATE:

TITLE:

PRINCIPAL INVESTIGATORS:

SUMMARY:

\section{REFERENCES:}

AREA:

FUNDING:

DATE:

TITLE:

PRINCIPAL INVESTIGATOR:

SUMMARY:

\section{REFERENCE:}

AREAS:

FUNDING:

DATE:

TITLE

PRINCIPAL INVESTIGATOR: SUMMARY:

\section{REFERENCE:}

AREAS:

FUNDING:

DATE:

TITLE:

PRINCIPAL INVESTIGATORS:
The reports include a dipole-dipole resistivity reconnaissance survey and an interpretation of the data. Methods used to interpret data and the problems encountered are outlined. Maps (scale 1:24,000) are included that show apparent and interpreted resistivity sections, interpreted electrical resistivity at $0-300^{\prime}$ and $1500^{\prime}-2000^{\prime}$, and a comparison of resistivity distribution with the geologic data.

Phoenix Geophysics, Incorporated, 1976; Ross, 1979

\section{Cove Fort \\ Department of Energy \\ 1979-1982}

Multielement Geochemistry of Three Geothermal Wells

Christensen, O. D., Earth Science Laboratory/University of Utah Research Institute Analyses of whole rock samples and of a sample slurry of drill cuttings were used to determine areal distribution of $\mathrm{As}, \mathrm{Hg}, \mathrm{Pb}$, and $\mathrm{Zn}$ in relation to sequential hydrothermal events. Models were developed for targeting geothermal drilling from geochemical zonation of elements.

Bamford and Christensen, 1979; Christensen, 1982

\section{Cove Fort}

Department of Energy

1979-1983

Geological and Geophysical Case Study

Moore, J. N., Ross, H. P., Ward, S. H., Earth Science Laboratory/University of Utah Research Institute

A geological study includes the regional stratigraphy, lithology, structure, mineralogy, alteration, and hydrology. Geophysical studies include reflection and refraction seismicity, microearthquakes, earth noise, detailed gravity, magnetics, dipole-dipole resistivity, electrical methods of IP, SP, and MT/AMT, radiometry, and heat flow. Well $\log$ interpretations are discussed.

Cook, Serpa, and Pe, 1980; Glenn and Ross, 1982; Moore and others, 1979; Ross, 1979; Ross, Moore, and Christensen, 1982; Ward, 1983b

\section{Cove Fort}

U.S. Geological Survey

1977

Environmental Analysis

Office of the Area Geothermal Supervisor

The geology, soils, air quality, noise, climate, hydrology, vegetation, socioeconomic characteristics, wildlife, and archaeological sites were studied to identify potential environmental impacts. Measures were outlined to lessen or eliminate adverse impacts The report includes plans of Phillips Petroleum and Union Oil Company to drill 31 wells.

U.S. Geological Survey, 1977

Cove Fort, Lund, Roosevelt, Thermo,

Department of Energy

1978

Environmental Overview Report on Utah Geothermal Resource Areas

White, K. L., University of Utah Environmental Studies Laboratory

The study assesses key issues which may influence the development of the KGRAs in southwestern Utah, such as hazardous pollution emissions, visibility reduction due to emissions, odor effects, natural water degradation, rare and endangered species, preservation of archaeological sites, noise, induced seismicity, and slope stability.

White and others, 1978

\section{Cove Fort, Roosevelt}

Department of Energy

1963-1979

Earthquake Study

Phillips Petroleum Company; Earth Science Laboratory/University of Utah Research Institute 
SUMMARY:

\section{REFERENCES:}

AREAS:

FUNDING:

DATE:

TITLE:

PRINCIPAL INVESTIGATOR: SUMMARY:

\section{REFERENCES:}

AREAS:

FUNDING:

DATE:

TITLE:

PRINCIPAL INVESTIGATOR:

SUMMARY:

\section{REFERENCE:}

AREAS:

FUNDING:

DATE:

TITLE:

PRINCIPAL INVESTIGATORS:

\section{SUMMARY:}

\section{REFERENCES:}

AREAS:

FUNDING:

DATE:

TITLE:

PRINCIPAL INVESTIGATOR:

SUMMARY:

\section{REFERENCE:}

AREAS:

FUNDING:

DATE:

TITLE:

PRINCIPAL INVESTIGATOR: SUMMARY:
Reports include earthquake and microearthquake data with listings of seismic events according to year, date, time, location, depth and magnitude. Maps showing epicenters and hypocenters were compiled for the study area.

Earth Science Laboratory/University of Utah Research Institute, 1979; Phillips Petroleum Company, 1979

Cove Fort, Roosevelt

Department of Energy

1974-1982

Industry-coupled Program

Department of Energy

The Department of Energy purchased geological, geophysical, seismic, geochemical, and temperature gradient data, along with drilling logs and flow tests from companies working at Roosevelt and Cove Fort. The Department of Energy released these data through University of Utah Research Institute open-file reports.

Aerial Surveys, 1978a, 1978b; Geonomics Incorporated, 1976b; Geothermal Power Corporation, 1978a, 1978b, 1980, 1982; GeothermEx Incorporated, 1977; Getty Oil Company, 1978a, 1978b; Helton Engineering and Geological Services, Incorporated, 1978; Thermal Power Company, 1976, 1977a, 1977b; Union Oil Company reports 1974-1979

Cove Fort, Roosevelt

Department of Energy

1977

Long-term Seismic Monitoring

Smith, R. B., University of Utah Department of Geology and Geophysics

Seismic monitoring from January 1 - June 30, 1977 of seismic signals generated by withdrawal of stream from a well at Roosevelt.

Smith, R. B., 1977a

Cove Fort, Roosevelt

Department of Energy

1977-1978

Regional Gravity and Aeromagnetic Survey

Brumbaugh, W. D., Carter, J. A., University of Utah Department of Geology and Geophysics

Six hundred seventy-one gravity stations were set up over an area of $1300 \mathrm{~km}^{2}$. Results of two gravity profiles with interpretive geologic cross-sections, terrain corrected Bouguer gravity anomaly map, and an isometric three dimensional gravity anomaly model are discussed. A regional aeromagnetic survey of the Mineral Mountains and the two thermal areas was done and the anomalies are described.

Brumbaugh, 1978; Brumbaugh and Cook, 1977; Carter, 1978; Carter and Cook, 1978

Cove Fort, Roosevelt

Department of Energy

1978

Investment Analysis

Cassel, T. A., University of Pennsylvania Energy Center

The study analyzes and models the investment behavior of companies involved in the development of hydrothermal electric power facilities. It provides a realistic and theoretically sound means for predicting capital investments in the development of hydrothermal well fields, and outlines investment considerations and financial attributes. A model is applied to Roosevelt Hot Springs and Cove Fort-Sulphurdale.

Cassel and others, 1978

Cove Fort, Roosevelt

Department of Energy

1978-1979

Geothermal Ground Noise Measurements

Laster, S. J., University of Tulsa Geophysics Laboratory

A survey of ambient seismic noise. 


\section{REFERENCES:}

\section{AREAS:}

FUNDING:

DATE:

TITLE:

PRINCIPAL INVESTIGATOR:

SUMMARY:

\section{REFERENCES:}

AREAS:

FUNDING:

DATE:

TITLE:

PRINCIPAL INVESTIGATOR:

SUMMARY:

\section{REFERENCES:}

AREA:

FUNDING:

DATE:

TITLE:

PRINCIPAL INVESTIGATOR:

SUMMARY:

\section{REFERENCES:}

AREA:

FUNDING:

DATE:

TITLE:

PRINCIPAL INVESTIGATOR: SUMMARY:

\section{REFERENCES:}

\section{AREA:}

FUNDING:

DATE:

TITLE:

PRINCIPAL INVESTIGATOR:

SUMMARY:

\section{REFERENCES:}

\section{AREA:}

FUNDING:

DATE:

TITLE:

PRINCIPAL INVESTIGATOR:
Laster and Douze, 1978; Douze and Laster, 1979

\section{Cove Fort, Roosevelt}

National Science Foundation

1974

Regional Geophysical Study

Ward, S. H., University of Utah Department of Geology and Geophysics

The reports include results of a dipole-dipole resistivity survey, electromagnetic soundings, vertical electric soundings, microearthquake monitoring, regional gravity survey, and an aeromagnetic survey over the Roosevelt Hot Springs, Mineral Mountains, and Cove Fort areas.

Ward, Cook, Nash, and others, 1974; Ward, Nash, and others, 1974

\section{Cove Fort, Roosevelt}

National Science Foundation

1976

Earthquake Surveys

Olson, G. L., University of Utah Department of Geology and Geophysics

The project covers two recording sessions for a 49 day period. P-wave delays, S-wave attenuation, and cumulative energy release were monitored to provide information on stress orientation and location of fault zones.

Olson, 1976; Olson and Smith, 1976

\section{Crystal Hot Springs}

Department of Energy

1980-1982

Utah State Prison Geothermal Project

Utah Energy Office

The objective of the project was to demonstrate the use of geothermal energy for direct utilization at the Utah State Prison. Crystal Hot Springs waters were developed for space and water heating at the prison's minimum security block. The project was divided into the following three phases: (1) resource assessment, (2) resource development, and (3) construction and inspection of demonstration.

Blair and Owen, 1981; Morrison-Knudson, 1982; Terra Tek, 1980a; Utah Energy Office, 1981

\section{Crystal Hot Springs}

Department of Energy, Utah Geological and Mineral Survey

1979-1981

Geothermal Investigation

Murphy, P. J., Utah Geological and Mineral Survey

The investigation includes a study of the geology, structure, and stratigraphy of the Traverse Mountains horst, shallow ground temperature survey, water chemistry of springs and test wells, and a study of the reservoir heat source and recharge system.

Murphy, 1981; Murphy and Gwynn, 1979a

\section{Fumarole Butte}

Department of Energy

1974-1978

Gravity Study

Smith, T. B., University of Utah Department of Geology and Geophysics

The study includes an overview of geology, lithologic descriptions, and structure. Three gravity surveys were done and geologic cross sections were drawn from interpreted gravity data. Simple Bouguer gravity map, aeromagnetic map, and geologic map were compiled.

Smith, 1974; Smith, Cook, and Peeples, 1978

\section{Fumarole Butte}

U.S. Geological Survey and University of Utah (Mineral Leasing Fund) 1979-1980

Geology and Petrology

Peterson, J. B., University of Utah Department of Geology and Geophysics 
SUMMARY:

\section{REFERENCES:}

\author{
AREAS: \\ FUNDING: \\ DATE: \\ TITLE: \\ PRINCIPAL INVESTIGATOR: \\ SUMMARY:
}

\section{REFERENCES:}

AREAS:

FUNDING:

DATE:

TITLE:

PRINCIPAL INVESTIGATOR:

SUMMARY:

REFERENCE:

AREA:

FUNDING:

DATE:

TITLE:

PRINCIPAL INVESTIGATOR:

SUMMARY:

REFERENCE:

AREA:

FUNDING:

DATE:

TITLE:

PRINCIPAL INVESTIGATOR:

SUMMARY:

\section{REFERENCES:}

AREA:

FUNDING:

DATE:

TITLE:

PRINCIPAL INVESTIGATOR: SUMMARY:

\section{REFERENCES:}

AREAS:

FUNDING:

DATE:

TITLE:

PRINCIPAL INVESTIGATORS:
The study discusses the geology, geophysics, water temperatures, geochronology, mineral and rock chemistry, geothermometry, and geothermal potential of the area. Peterson, 1979; Peterson and Nash, 1980

\section{Joseph, Monroe \\ Department of Energy \\ 1978}

Gravity and Ground Magnetic Surveys

Halliday, M. E., University of Utah Department of Geology and Geophysics

A regional gravity survey using 948 stations was made to produce a Bouguer anomaly map. A magnetic survey with a total of 840 ground stations along 19 profiles produced a diurnal-corrected total magnetic intensity anomaly map. Resulting data have provided valuable information on large scale faults, particularly those controlling hot springs. Halliday, 1978; Halliday and Cook, 1978; Halliday and others, 1978

\section{Joseph, Monroe}

U.S. Geological Survey

1976

Audiomagnetotelluric Survey

Gardner, Susan, U.S. Geological Survey

The publication is a data log and station location map from an 11 station AMT survey. Gardner, Williams, and Brougham, 1976

\section{Lund}

U.S. Geological Survey

1976

Audiomagnetotelluric Survey

Gardner, Susan, U.S. Geological Survey

The publication is a data log and station location map from a 10 station AMT survey.

Gardner, Williams, and Hoover, 1976

\section{Midway}

Department of Energy, Utah Geological and Mineral Survey

1979

Geothermal Potential

Kohler, J. F., Utah Geological and Mineral Survey

The study involves the geology and structure of the area, chemical analyses and geothermometry of the thermal waters, thermal gradients, gravity anomalies, and modeling of heat source theories.

Kohler, 1979; Kohler and Kolesar, 1979

\section{Monroe}

Department of Energy

1980-1981

Exploration Case History

Hulen, J. B., Earth Science Laboratory/University of Utah Research Institute

The project examines the exploration techniques used to evaluate the Monroe KGRA and their usefulness in predicting resources. Techniques used include geology, alteration and spring geochemistry, various logs from test holes, heat flow data, and geophysical surveys. A reference list of publications on the Monroe Hot Springs and vicinity was compiled.

Hulen and Sandberg, 1981; Earth Science Laboratory/University of Utah Research Institute, 1980

\section{Monroe, Red Hill}

Department of Energy

1978-1981

Geophysical Study

Mase, C. W., Halliday, M. E., University of Utah Department of Geology and Geophysics 
SUMMARY:

\section{REFERENCES:}

AREAS:
FUNDING:
DATE:
TITLE:
PRINCIPAL INVESTIGATORS:
SUMMARY:

REFERENCES:

AREAS:

FUNDING:

DATE:

TITLE:

PRINCIPAL INVESTIGATOR:

SUMMARY:

\section{REFERENCES:}

AREA:

FUNDING:

DATE:

TITLE:

PRINCIPAL INVESTIGATOR:

SUMMARY:

\section{REFERENCES:}

AREA:

FUNDING:

DATE:

TITLE:

PRINCIPAL INVESTIGATOR:

SUMMARY:

\section{REFERENCE:}

\section{AREA:}

FUNDING:

DATE:

TITLE:

PRINCIPAL INVESTIGATORS:

\section{SUMMARY:}

The exploration of Monroe and Red Hill hot springs included extensive studies of the geology, lithology, structure, well log interpretations, spring geochemistry, and alteration. The geophysical studies included a gravity survey with 1000 stations, a magnetic survey with 19 lines and 840 stations, a resistivity survey, and interpretive geologic profiles. Temperature depth profiles, thermal gradient values, heat flow, and thermal conductivity values were also determined.

Chapman and Harrison, 1978; Halliday, 1978; Halliday and Cook, 1978; Halliday and others, 1978; Kilty and others, 1979; Mase, 1979; Mase and others, 1978; Sandberg, 1980

\section{Monroe, Red Hill}

Department of Energy

1980-1982

Utilization of Monroe Geothermal Resource

Blair, K. C., Harrison, R. J., Terra Tek

The study includes an overview of the geology, geophysics, temperature-depth profiles, flow rates, reservoir assessment, production system design, costs, and practicability for development of space heating at Monroe.

Blair, 1980; Blair and Owen, 1982; Blair and others, 1980; Harrison, 1980; Harrison and others, 1980; Terra Tek, 1980b

\section{Monroe, Roosevelt, Thermo}

Utah Geological and Mineral Survey

1973-1975

Geology, Water Temperature, and Thermal Gradient Study

Petersen, C. A., Utah Geological and Mineral Survey

The geology and temperature estimates of the Roosevelt and Thermo hot spring areas were studied. Other information presented in the reports includes water chemistry for Roosevelt, and thermal gradient, heat flow, and alteration studies in the Roosevelt and Monroe areas.

Petersen, 1973, 1975a, 1975b; Whelan and Petersen, 1974

\section{Newcastle}

Department of Energy

1981

Heat Flow and Geothermal Assessment of the Escalante Desert with emphasis on the Newcastle KGRA

Clement, M. D., University of Utah Department of Geology and Geophysics

The project assesses the geothermal potential of Escalante Desert using recently acquired heat flow values to define regional heat flow magnitude. Thermal gradients and heat flow determinations of the Newcastle geothermal system were studied.

Clement, 1981; Clement and Chapman, 1981

\section{Newcastle}

U.S. Geological Survey

1976

Helium Sniffer Test

Denton, E. H., U.S. Geological Survey

Two hundred soil-gas samples were collected two feet below the surface and analyzed for helium. A contour map of helium concentrations was produced.

Denton, 1976

\section{Roosevelt}

Department of Energy

1977-1978

Hydrothermal Alteration

Bryant, N. L., Parry, W. T., University of Utah Department of Geology and Geophysics

Petrologic, X-ray, and chemical methods were used to characterize systematic changes in chemistry and mineralogy in core from drill holes. A model that accounts for the zonation is included in the reports. 


\section{REFERENCES:}

AREA:

FUNDING:

DATE:

TITLE:

PRINCIPAL INVESTIGATOR: SUMMARY:

\section{REFERENCES:}

AREA:

FUNDING:

DATE:

TITLE:

PRINCIPAL INVESTIGATOR: SUMMARY:

\section{REFERENCES:}

AREA:

FUNDING:

DATE:

TITLE:

PRINCIPAL INVESTIGATOR: SUMMARY:

\section{REFERENCES:}

AREA:

FUNDING:

DATE:

TITLE:

PRINCIPAL INVESTIGATOR: SUMMARY:

\section{REFERENCES:}

AREA: FUNDING:

DATE:

TITLE:

PRINCIPAL INVESTIGATORS:
Bryant, 1977; Bryant and Parry, 1977; Parry, 1978; Parry and others, 1978

\section{Roosevelt}

Department of Energy

1977-1982

Geology, Geochemistry, and Geophysics

Earth Science Laboratory/University of Utah Research Institute

The Department of Energy funded an intensive study of Roosevelt Hot Springs area and many aspects of the spring have been explored. These include geology, lithology, structure, mineralization, and alteration. Several wells have been drilled and the lithologic, temperature, caliper, porosity, density, and resistivity characteristics studied. Gravity, seismic, magnetic, resistivity, and electrical (IP, DC, MT, EM, SP) surveys have been conducted and the resulting data have been interpreted and anomaly maps and profiles drawn. Geochemical analyses of water, soil, gas, rock, and isotopes has been done, as well as geothermometer studies. Heat flow rates, thermal gradients, measured water temperatures, and calculated reservoir temperatures have been studied, and the reservoir size has been estimated

Ballantyne, 1980; Ballantyne, G. H., 1978, Ballantyne, J. M., 1978; Ballantyne and Parry, 1978; Bamford and others, 1980; Capuano and Bamford, 1978; Frangos and Ward, 1980; Gertson and Smith, 1979; Glen and Hulen, 1979b; Hulen, 1978; McKinney, 1978; Nielson, 1978; Nielson and others, 1978; Sill, 1981, 1982; Sill and Johng, 1979; Smith, J. L., 1980; Wannamaker, 1978; Wannamaker and others, 1980

\author{
Roosevelt \\ Department of Energy \\ 1978-1980 \\ Heat Flow \\ Chapman, D. S., University of Utah Department of Geology and Geophysics
}

The investigation used thermal gradient data, thermal conductivity measurements, and heat flow determinations from drill holes to determine the geometry and temperature of the Roosevelt geothermal system. Shallow heat flow surveys across faults were also used to study the fault geometry and fluid flow of the hydrothermal reservoir. Wilson and Chapman, 1978, 1979, 1980

\section{Roosevelt}

Department of Energy

1979

Structural Evolution of the Geothermal Reservoir

Yusas, M. R., University of Utah Department of Geology and Geophysics

The structure and fracture systems of the geothermal reservoir were analyzed. Strain relief was measured to determine active and residual stresses. A structural model was developed for the reservoir.

Yusas, 1979b; Yusas and Bruhn, 1979

\section{Roosevelt}

Department of Energy

1979-1982

Isotope Study

Bowman, J. R., University of Utah Department of Geology and Geophysics

The reports discuss isotopic analyses of silicates, carbonates, regional spring waters, and the interaction of thermal waters with the reservoir rock at Roosevelt. Hot spring alteration products, origin of thermal waters, and the extent of isotopic exchange were studied.

Bowman, 1979; Bowman and Rohrs, 1981; Bowman and others, 1982; Rohrs, 1980; Rohrs and Bowman, 1980

\section{Roosevelt}

Department of Energy, National Science Foundation

1973-1976

Geology, Geochemistry, and Geophysics

Parry, W. T., Ward, S. H., University of Utah Department of Geology and Geophysics 
SUMMARY:

\section{REFERENCES}

AREA:

FUNDING:

DATE:

TITLE:

PRINCIPAL INVESTIGATOR:

SUMMARY:

REFERENCE:

AREA:

FUNDING:

DATE:

TITLE:

PRINCIPAL INVESTIGATOR: SUMMARY:

\section{REFERENCES:}

AREA:

FUNDING:

DATE:

TITLE:

PRINCIPAL INVESTIGATOR: SUMMARY:

\section{REFERENCES:}

AREA:

FUNDING:

DATE:

TITLE

PRINCIPAL INVESTIGATORS: SUMMARY:

\section{REFERENCES:}

AREA:

FUNDING:

DATE:

TITLE:

PRINCIPAL INVESTIGATOR: SUMMARY

\section{REFERENCES:}

AREA:

FUNDING:

DATE:
The 1977 reports summarize the research and exploration efforts that took place between 1973 and 1976 at the Roosevelt thermal area. The reports discuss work done on the geology, spring deposits, alteration, and water chemistry. Microearthquakes, gravity, and magnetics were used to define the regional setting, resistivity and heat flow were used to localize the convective hydrothermal system, and magnetotellurics, gravity, and magnetics were used in attempts to locate the heat source.

Parry, Nash, Bowman, and others, 1977; Parry, Nash, and Ward, 1977; Ward and others, 1977

\section{Roosevelt}

National Science Foundation

1976

Magnetic Survey

Petrick, W. E., University of Utah Department of Geology and Geophysics

The study involves a vertical magnetic dipole survey at Roosevelt Hot Springs.

Petrick, 1976

\section{Roosevelt}

National Science Foundation

1976

Resistivity Survey

Ward, S. H., University of Utah Department of Geology and Geophysics

The project involves three surveys using different dipole spacing. The data were interpreted and modeled. The study included collection and interpretation of drill hole information, porosity and effects of clay alteration on resistivity, and heat source speculation.

Ward and Sill, 1976a, 1976b

\section{Roosevelt}

U.S. Geological Survey

1976-1977

Environmental Analysis

Durham, Jon, U.S. Geological Survey

Geology, soils, air quality, noise, climate, hydrology, vegetation, wildlife, and archeological sites were explored in an effort to identify potential environmental impacts of deep geothermal exploratory test wells drilled by Phillips Petroleum Company. Measures were outlined to lessen or eliminate adverse impacts on the environment. Durham, 1977; U.S. Geological Survey, 1976

\section{Roosevelt}

U.S. Geological Survey

1977-1981

Helium and Mercury Study

Hinkle, M. E., Denton, E. H., U.S. Geological Survey

The study outlines the relationship of helium and mercury concentrations in soils and gases to geothermal and geologic features.

Denton, 1977; Hinkle 1980, 1981; Hinkle and Harms, 1978; Hinkle and others, 1978

\section{Roosevelt, Mineral Mountains}

Department of Energy

1976-1982

Quaternary Magmatic System

Nash, W. P., University of Utah Department of Geology and Geophysics

Quaternary silicic volcanic rocks associated with the Roosevelt Hot Springs geothermal area were investigated by studying the geology, geochemistry, mineralogy, and geothermometers. The source region was discussed.

Evans and Nash, 1978; Nash, 1976; Nash and Crecraft, 1982; Nash and Evans, 1978

Sandy

Department of Energy

$1977-1982$ 
TITLE:

PRINCIPAL INVESTIGATOR:

SUMMARY:

\section{REFERENCES:}

AREA:

FUNDING:

DATE:

TITLE:

PRINCIPAL INVESTIGATOR:

SUMMARY:

\section{REFERENCES:}

\section{AREA:}

FUNDING:

DATE:

TITLE:

PRINCIPAL INVESTIGATOR:

SUMMARY:

REFERENCE:

AREA:

FUNDING:

DATE:

TITLE:

PRINCIPAL INVESTIGATOR:

SUMMARY:

\section{REFERENCE:}

\section{AREA:}

FUNDING:

DATE:

TITLE:

PRINCIPAL INVESTIGATOR:

SUMMARY:

\section{REFERENCE:}

Floral Greenhouse Geothermal Project

Utah Roses, Incorporated

The objective of the project was to convert an existing six acre greenhouse from gas and oil boilers to geothermal heat provided by Crystal Hot Springs geothermal resource. The test well $(1,527 \mathrm{~m})$ did not produce water as warm as expected, only $50^{\circ} \mathrm{C}$ with a slight flow; however, it does provide base load heating.

Energy Services, Incorporated, 1982; Kunze and Stoker, 1979; Kunze and others, 1980; Miller Floral Company, 1977; Utah Roses, Incorporated, 1978; Willis, 1980

\section{Thermo}

Department of Energy

1977

Gravity and Ground Magnetic Survey

Sawyer, R. F., University of Utah Department of Geology and Geophysics

A regional survey comprised of 273 new gravity and magnetic stations and incorporating 104 previous gravity stations was done. The data collected helped discern structural features, delineate between lithologies, and identify areas of hydrothermal alteration. Models and profile interpretations were made.

Sawyer, 1977; Sawyer and Cook, 1977

\section{Thermo}

U.S. Geological Survey

1976

Audiomagnetotelluric Survey

Gardner, Susan, U.S. Geological Survey

The publication is a data $\log$ and station location map from a 13 station AMT survey. Gardner, Williams, and Long, 1976

\section{Thermo}

U.S. Geological Survey

1977

Environmental Analysis

Durham, Jon, U.S. Geological Survey

Geology, soils, air quality, noise, climate, hydrology, vegetation, wildlife, and archeological sites were explored in an effort to identify potential environmental impacts of a geothermal exploratory test well drilled by Republic Geothermal, Incorporated. Measures were outlined to lessen or eliminate adverse impacts on the environment.

Durham and Hoops, 1977

\section{Wasatch Hot Springs}

Department of Energy

1984

Geothermal Heating for the Children's Museum

Karlsson, Thorbjorn, Oregon Institute of Technology

The report evaluates the possibility of using Wasatch Hot Springs (along with a natural gas backup system) to heat the Children's Museum. It recommended drilling an exploratory well to establish the underground flow path of the thermal system, a necessary step before being able to determine the heating potential of the spring.

Karlsson, 1984 


\section{CURRENT ACTIVITIES}

AREA:

FUNDING:

DATE:

TITLE:

PRINCIPAL INVESTIGATOR: SUMMARY:

AREA:

FUNDING:

DATE:

TITLE:

PRINCIPAL INVESTIGATOR: SUMMARY:

\section{Utah}

Utah Division of Water Rights

1985

Regulatory Authority over Geothermal Resources

Mann, John, Water Rights

Under the Geothermal Resource Conservation Act of 1981, Water Rights maintains regulatory control over geothermal exploration and development in Utah by authorizing drilling permits for all exploratory wells, collecting the well logs and drilling reports, and overseeing the unitization of geothermal areas.

\section{Utah}

Utah Energy Office

1985

Geothermal Permitting Manual

Burks, Jeff, Utah Energy Office

The Utah Energy Office is writing a geothermal permitting manual which details the state and federal permits necessary to develop a geothermal resource in Utah. 


\section{CURRENTLY DEVELOPED THERMAL AREAS}

SITE (Developer)

Belmont (Udy) Hot Springs

Cove Fort (Mother Earth Industries)

Crystal Hot Springs (Utah Roses)

Crystal Hot Springs (Utah State Prison)

Crystal (Madsens) Hot Springs

Laverkin

Midway

Monroe Hot Springs

Newcastle (Christensen Brothers, Dick Hildebrand)

Roosevelt Hot Springs (Utah Power and Light and Phillips Petroleum Company now Intermountain Geothermal)

Saratoga Hot Springs

Utah Hot Springs

Veyo

\section{APPLICATION}

swimming pool and mineral bath electrical (binary) - power sold to Provo City through UP\&L lines, 2.7 megawatt power plant with plans to increase production greenhouses space heating swimming pool, mineral bath, and space heating mineral bath

space heating and swimming pool swimming pool and mineral bath greenhouses

electrical (direct flash) -20
megawatt power plant

space heating

greenhouses

swimming pool 


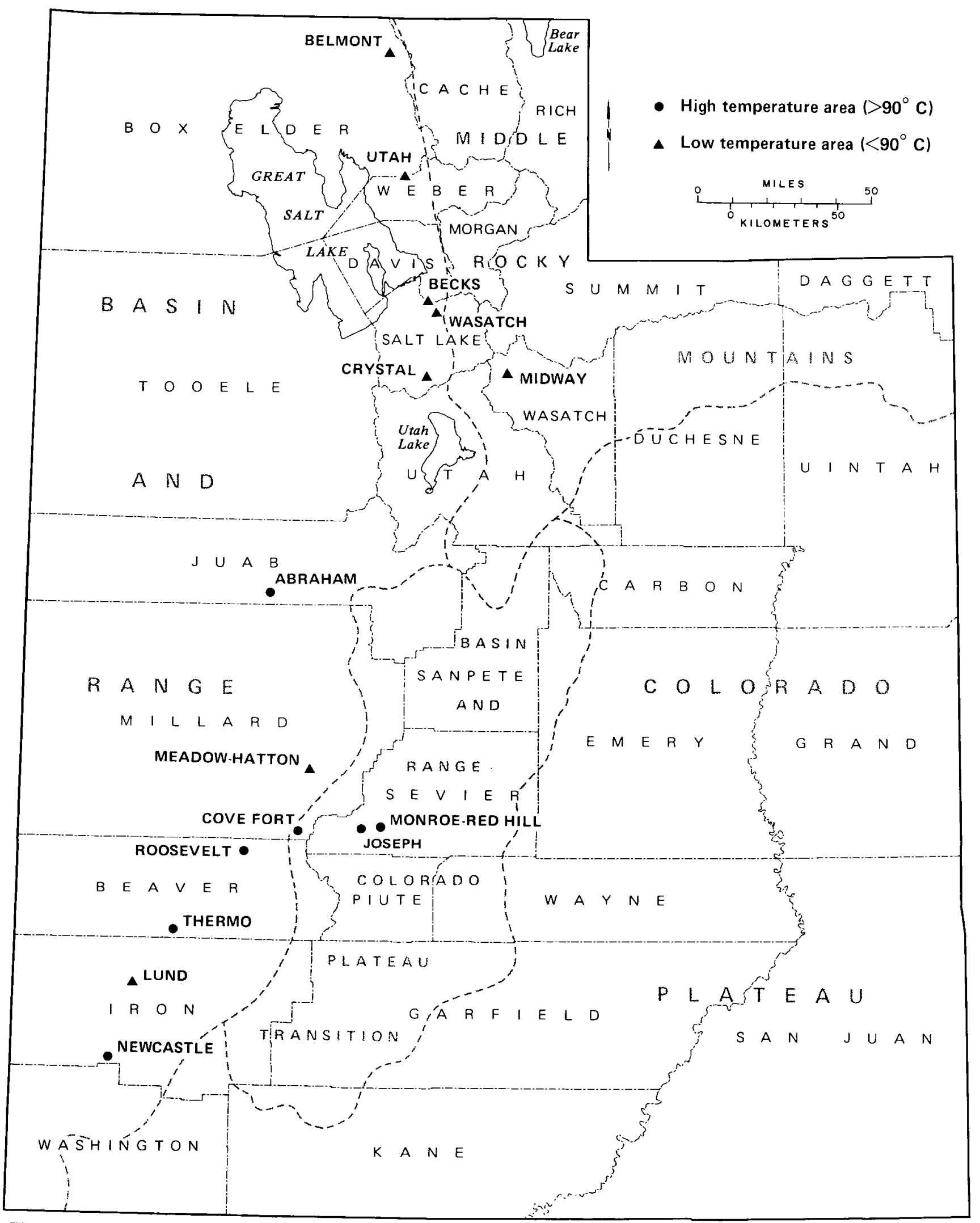

Figure 1. Map of Utah counties, thermal areas, and physiographic provinces listed in the geographic index.

High-temperature areas have geological and geophysical references in bibliography. 


\section{GEOGRAPHIC INDEX}

\author{
UNITED STATES \\ Bell, 1855 \\ Berge and others, 1981 \\ Berry and others, 1980 \\ Brook and others, 1979 \\ Bryan, 1919 \\ Brown and Mansure, 1981 \\ Clark and others, 1976 \\ Clarke, 1914 \\ Combs and others, 1982 \\ Crook, 1899 \\ Darton, 1920 \\ Davis and others, 1980 \\ DiPippo, 1978, 1984 \\ Diment and others, 1975 \\ Duffield and Guffanti, 1981 \\ Smith and Ponder, 1982 \\ Smith and Shaw, 1973, 1975, 1979 \\ Smith, R. L., and others, 1978 \\ Sorey, 1975 \\ Sorey and others, 1982 \\ Spicer, 1964 \\ Stearns and others, 1937 \\ Swanson, 1977 \\ Teshin and others, 1979 \\ Truesdell, 1973 \\ U.S. Geological Survey, 1979c, \\ 1983a, 1983b \\ Walker and Entingh, 1981 \\ Ward, 1975 \\ Waring, 1951, 1952, 1953, 1965 \\ White, 1938, 1955
}

Fitch, 1927

Foley, 1984

Foley and others, 1979

Foley and others, 1980

Fornes, 1981

Goff and Decker, 1983

Goff and others, 1981

Grose, 1975

Guffanti and Nathenson, 1980, 1981

Heiken and others, 1982

Hulen and Sibbett, 1981

Koenig and others, 1976

Kron and Heiken, 1980

Kron and Stix, 1982

Lachenbruch and Sass, 1977

Ladd, 1980

Lin, 1981

Mariner and others, 1978

Miller, 1976

Muffler, 1976

Murphy and Entingh, 1981

Nathenson and others, 1983

Nimmons and others, 1979

Peale, 1872, 1886

Penta, 1960

Phelps and others, 1978

Potter and others, 1975

Reed, 1977

Reed and Sorey, 1981

Reed and others, 1983

Reimer and others, 1976

Renner and others, 1975

Sammel, 1979

Theberge, 1980

Sass and Lachenbruch, 1975

Sass and Munroe, 1974

Sass and others, 1976

Sass and others, 1981

Skalka, 1979

\section{REGIONAL}

\section{Westem United States}

Birdseye, 1969

Bowman and others, 1980

Butler, 1975

Callender and others, 1977

Cassel and others, 1979

Christiansen and Lipman, 1972

Combs and others, 1983

Crittenden, 1951

Crowley, 1977, 1978

Darling and Chapman, 1979

Dickson and Tunell, 1968

Eaton, 1979

Feth and Barnes, 1979

Foley and Dorscher, 1982

Fuchs and Huttrer, 1975

Geonomics, Incorporated, 1976a

Godwin and others, 1971

Goff and Waters, 1980

Grim and others, 1978

Hallin, 1973

Isselhardt and others, 1977

Kaczynski and others, 1981

Kilty, 1980

Knauf, 1981

Koenig, 1971

Lachenbruch, 1980

Lipman, 1979

Lipman and others, 1972

Luedke and Smith, 1978

Lunis and Toth, 1982

Mabey and others, 1978

Mariner, Brook, and others, 1983

Mariner and others, 1977

Matlick and Smith, 1976

Meidav and Sanyal, 1976

Meyer and Bronder, 1980
Nathenson and Muffler, 1975

Nehring and others, 1979

Nichols, 1979

O'Connell and Kaufmann, 1976

Otte, 1980

Pollard, 1978

Ruscetta, 1982

Sass and others, 1971

Schufle, 1963

Sifford, 1981

Smith and Luedke, 1981

Smith and Matlick, 1976

Smith, J. L., and others, 1978

Smith, J. L., and others, 1977

Smith, J. L., and others, 1979

Smith, J. L., and others, 1980

Smith, M. C., and others, 1982

Smith, M. C., and others, 1985

Stanley and others, 1977

Sung and others, 1979

TRW Systems Group, 1975, 1976

Thomaidis, 1974

Tuttle and others, 1980

Ward, 1977, 1978

Ward, 1979

White, 1963

White and others, 1982

White and others, 1979a, 1979b, $1979 \mathrm{c}$

Wright and others, 1978

\section{REGIONAL}

Basin and Range Province (includes High Plateaus subprovince)

Armstrong, 1963, 1970

Benoit and Butler, 1983

Best and Brimhall, 1974

Blackwell, 1983

Blackwell and Chapman, 1977

Bortz, 1983

Brown and Nash, 1978

Bucher, 1971

Corwin and Hoover, 1979

Costain, 1973

Crowley, 1977, 1978

Edmiston, 1979, 1982

Edmiston and Benoit, 1985

Evans, 1978

Fiore, 1980

Fishman, 1976

Fleck and others, 1975

Glenn and others, 1982

Greider, 1976

Hogg, 1972a 
Holmes, 1979

Koenig and McNitt, 1983

Lachenbruch and Sass, 1978

Leeman and Rogers, 1970

Liaw and Suyenaga, 1982

Loring, 1972

Mabey and others, 1983

Mackin, 1960a

Mainzer, 1978

Mariner, Presser, and Evans, 1983

Meinzer, 1924

Meyer and others, 1979

Mifflin, 1983

Nehring and Mariner, 1979

Nielson, 1980

Osmond, 1958

Overton and Hanold, 1977

Ritzma, 1972

Rowan and others, 1983

Rowley and others, 1978

Scholz and others, 1971

Smith, R. B., 1977b

Smith and Sbar, 1974

Stewart, 1971, 1983

Stewart and others, 1977

Stringfellow, 1982

Tischler and others, 1964

Wannamaker, 1983

Ward, 1983b

Ward and others, 1979, 1980, 1981

White and Heropoulos, 1983

Zoback and Anderson, 1983

\section{REGIONAL}

\section{Colorado Plateau}

Bodell, 1981

\section{UTAH}

Ames and Sand, 1959

Anno and others, 1978

Batty and others, 1975

Bliss, 1983

Bowen, 1975

Brown, 1982a

Cleary, 1978

Cole, 1983

Cook and others, 1975

Costain and Wright, 1969

Department of Geology and Geophysics, University of Utah, 1979

England and Johnson, 1976

Evans, 1979

Geothermal Resources Council, 1980a, 1980b, 1981a, 1981e, $1981 \mathrm{~g}, 1985 \mathrm{~b}$

Goode, 1978

Green, 1979
Green and Wagstaff, 1979

Hanny and Lunis, 1979

Hewitt and others, 1972

Heylmun, 1966

Kaliser and Grey, 1970

Klauk, 1982, 1985

Kolesar and Degraff, 1977

McNitt, 1965

Milligan, 1967

Milligan and others, 1966

Mundorff, 1970

Olson and Smith, 1977

Parry and Cleary, 1978

Renner and Galyardt, 1976

Rogers, 1978

Rowley and others, 1975

Rush, 1983

Sandquist and others, 1972

Selk, 1976

Smith, M. R., 1979, 1982

Smith and Sharda, 1978

Stowe, 1977

Swanberg, 1974

Utah Department of Natural Resources, 1976

Utah Geological and Mineral Survey, 1980,1983

Ward, Cook, Nash, and others, 1974

Ward, Cook, Parry and others, 1974

Ward, Nash, and others, 1974

Whelan, 1970

White, 1980

Wright, 1966

Zeitz and others, 1976

UTAH

\section{Central}

Snow, 1978

\section{UTAH}

Northern

Gilbert, 1890

Khattab, 1969

\section{UTAH}

Southern

Wechsler and Smith, 1979

\section{UTAH}

Southwestern

Best and others, 1980

Crosby, 1973

Mackin, 1960b

Rowley and others, 1979

Sill and others, 1977

Wannamaker and others, 1983

\section{UTAH}

\section{Wasatch Front}

Anderson, 1978

Cole, 1981, 1982, 1983

Pack, 1927

Talmage, 1929

\section{UTAH}

Western

Evans, 1980, 1982

Evans and Brown, 1980, 1981

Geothermal Resources Council Bulletin, 1981c

Goode, 1979

Mehnert and others, 1978

Montgomery, 1973

Nash and others, 1978

Rush, 1977

Turley and others, 1979

\section{COUNTIES}

\section{Beaver}

Abou-Sayed and others, 1977

Adhidjaja, 1981

Aerial Surveys, 1978a, 1978b

Aleinkoff and others, in press

Allen, 1983

Ash and others, 1979

Asten, 1983

Atkinson, 1981

Atkinson and Meyer, 1980

Ballantyne, G.H., 1978

Ballantyne, J.M., 1978, 1980

Ballantyne and Parry, 1978, 1979

Bamford, 1978

Bamford and Christensen, 1979

Bamford and others, 1980

Barosh, 1960

Batzle and Simmons, 1976

Berge and others, 1976, 1977

Berge and others, 1981

Best and Grant, in press

Best and Keith, 1983

Best and others, in press

Bowers, 1978

Bowman, 1979

Bowman and others, 1982

Bowman and Rohrs, 1981

Brown, 1977

Brown, 1982b, 1983

Brown and Mansure, 1981

Brumbaugh, 1978

Brumbaugh and Cook, 1977

Bryant, 1977

Bryant and Parry, 1977

Burbank City Public Service

Department, 1977 
Butz, 1980

Butz and Plooster, 1979

Cady, 1983

Campbell and others, 1984

Campbell and Flanigan, 1982

Capuano and Bamford, 1978

Capuano and Cole, 1982

Carlston, 1982

Carson and Livesay, 1981

Carter, 1978

Carter and Cook, 1978

Carter and others, 1977

Case, 1977

Caskey and Shuey, 1975

Cassel and others, 1978

Christensen, 1982

Christensen and others, 1980

Christensen and others, 1983

Chu, 1980

Chu and others, 1979

Ciancanelli, 1977

Ciancanelli and Corman, 1978

Clark, 1977

Cole, 1983

Combs and others, 1982

Combs and others, 1983

Condie, 1960

Condie and Barsky, 1972

Conrad, 1969

Cook and Carter, 1978

Cook, Serpa, and Pe, 1980

Cook, Serpa, Pe, and Brumbaugh, 1980

Cook and others, 1981

Cook and others, 1984

Cordova and Mower, 1976

Crebs, 1975

Crebs and Cook, 1976

Crebs and others, 1977

Cremer, 1980

Crowley, 1977, 1978

Cunningham and Steven, 1979b

Cunningham and others, 1983

Cunningham and others, 1984

Denton, 1977

DiPippo, 1985

Douze and Laster, 1979

Durham, 1977

Durham and Hoops, 1977

Earth Science Laboratory/University of Utah Research Institute, 1979

East, 1981

Edmiston and Benoit, 1985

Erickson, 1973

Erickson and Dasch, 1963

Evans, 1977

Evans and Nash, 19751978
Evans and Nielson, 1982

Evans and Steven, 1982

Flanigan and Campbell, 1981

Foley, 1982

Forrest, 1980

Frangos and Ward, 1980

Gabbert, 1980

Gardner, Williams, and Long, 1976

Geonomics, Incorporated, 1976b

Geothermal Power Corporation, $1978 \mathrm{a}, 1978 \mathrm{~b}, 1982$

Geothermal Resources Council Bulletin, 1981b, 1981h, 1981i, 1981k, 1982a, 1982b, 1982f, $1982 \mathrm{~g}, 1982 \mathrm{~h}, 1982 \mathrm{k}, 1983 \mathrm{a}$, 1983b, 1984a, 1984b, 1984c, 1984d, 1984e, 1984f, 1984g, $1985 \mathrm{a}, 1985 \mathrm{c}$

GeothermEx, Incorporated, 1977

Geotronics Incorporated, 1976

Gertson and Smith, 1979

Getty Oil Company, 1978a, 1978b

Glenn and Hulen, 1979a, 1979b

Glenn, Hulen, and Nielson, 1980

Glenn and Ross, 1982

Glenn and others, 1982

Hahl and Mundorff, 1968

Haugh, 1978a

Helton Engineering and Geological Services, Incorporated, 1978

Hewitt and others, 1972

Hinkle, 1980, 1981

Hinkle and Harms, 1978

Hinkle and others, 1978

Hoover, 1974

Huertas, 1979

Hughes, 1983

Hulen, 1978

Iyer, 1980

Iyer and others, 1980

Jamin, 1982

Jensen and Qidwai, 1980 ?

Katz, 1977

Katzenstein and Jacobson, 1976

Kellogg and Cook, 1979

Keys, 1979

Koenig and others, 1976

Koenig and Petersen, 1977

Kruger and Semprini, 1983

Laster and Douze, 1978

Lee, 1907

Leitner, 1978

Lenzer and others, 1976

Liaw and Suyenaga, 1982, 1983

Liese, 1957

Lin, 1981

Lipman and others, 1975

Lipman and others, 1978
Lovell and others, no date

Luth and Hardee, 1980

Lynch and Nash, 1980

Mabey and Virgin, 1980

Machette, 1982

Machette and others, 1984

Mariner and others, 1978

Mariner, Presser, and Evans, 1983

Mathews, 1979

Mathews and LaDelfe, 1981

Matlick and Shiraki, 1981

McHugh, Ficklin, and Miller, 1980, 1981

McHugh, Ficklin, Miller, and Preston, 1981

McHugh and Miller, 1981, 1982

McHugh, Miller, and Ficklin, 1984

McHugh, Motooka, and Tucker, 1980

McKinney, 1978

Micro Geophysics, 1977

Moore, 1980a, 1980b

Mooore and others, 1979

Moore and others, 1983

Mower, 1978

Mower and Cordova, 1973, 1974

Mudgett, 1964

Murphy and Entingh, 1981

Nash, 1976, 1981

Nash and Crecraft, 1982

Nash and Evans, 1978

Nash and others, 1978

Nash and others, 1980

Nathenson and Muffler, 1975

Nelson and Bromfield, 1979

Nielson, 1978, 1980

Nielson and Moore, 1979

Nielson and others, 1978

Nielson and others, 1979

Nielson and others, 1980

Nielson and others, in press

Olson, 1976

Olson and Smith, 1976

Olson and others, 1976

Parry, 1978

Parry, Ballantyne, and Bryant, 1980

Parry, Ballantyne, Bryant, and Dedolph, 1980

Parry, Nash, and Ward, 1977

Parry, Nash, Bowman, and others, 1977

Parry and others, 1976

Parry and others, 1978

Pera, 1978a

Petersen, 1973, 1975a, 1975b

Peterson, 1972, 1974

Petrick, 1976

Phillips Petroleum Company, 1979, 1980 
Phoenix Geophysics, Incorporated, 1976

Pushkar and Condie, 1973

Rasband, 1981, 1982, 1983

Reimer, 1979

Robinson and Iyer, 1979, 1981

Rodriguez, 1960

Rohrs, 1980

Rohrs and Bowman, 1980

Rohrs and Parry, 1978

Ross, 1979

Ross and Moore, 1985

Ross, Moore, and Christensen, 1982

Ross, Nielson, and Moore, 1982

Ross and others, 1981

Rowley, 1978

Rowley and Lipman, 1975

Roxlo, 1980

Rudisill, 1978

Sandberg, 1980

Savino and others, 1982

Sawyer, 1977

Sawyer and Cook, 1977

Schaff, 1981

Schmoker, 1972

Seismic Exploration Incorporated, 1977

Serpa, 1980

Serpa and Cook, 1979

Shannon, Goff, and others, 1983

Shannon, Pettitt, and others, 1983

Sibbett and Nielson, 1980

Sill, 1981, 1982

Sill and Bodell, 1977

Sill, Chapman, and others, 1977

Sill and Johng, 1979

Sill and Ward, 1978

Sill, Ward, and others, 1977

Smith, G. E., 1977

Smith, R. B., 1977a

Smith, J. L., 1980

Steven, Cunningham, and Anderson, 1984

Steven and Morris, 1983a, 1984

Steven, Rowley, and Cunningham, 1978, 1984

Steven and others, 1979

Stringfellow, 1982

Thangsuphanich, 1976

Thermal Power Company, 1976, 1977a, 1977b

Tripp, 1978

Tripp and others, 1976

Tucker and others, 1980

U.S. Geological Survey, 1972b, 1976, 1979a
Union Oil Company, 1973, 1974, 1976a, 1976b, 1977, 1978a, 1978b, 1978c, 1978d, 1978e, 1978f, 1978g, 1979a, 1979b

University of Denver, Denver Research Institute, 1978

Wannamaker, 1978

Wannamaker and Hohmann, 1980

Wannamaker and others, 1978

Wannamaker and others, 1979

Wannamaker and others, 1980, 1983

Ward, 1983a, 1983b

Ward, Bowman, and others, 1978

Ward, Cook, Nash, and others, 1974

Ward, Glenn, and others, 1975

Ward, Parry, and others, 1978

Ward, Rijo, and Petrick, 1975

Ward and Sill, 1976a, 1976b, 1984

Ward and others, 1977

Ward and others, 1981

Whelan, 1977

White and others, 1978

Wilson, 1980

Wilson and Chapmam, 1978, 1979, 1980

Young and others, 1979

Yusas, 1979a, 1979b

Yusas and Bruhn, 1979

Zandt and others, 1982

Zimmerman, 1961

\section{Box Elder}

Berge and others, 1981

Carpenter, 1913

Crowley, 1978

Davis, 1984

Davis and Kolesar, 1985

Doelling and others, 1980

Geothermal Resources Council Bulletin, 1982c

Klauk and Budding, 1984

Murphy, 1978

Murphy and Gwynn, 1979b

Pera and others, 1978

Zohdy and Bisdorf, 1976

Cache

de Vries, 1982, 1983

\section{Carton}

Smedley and others, 1978

Davis

Cole, 1981

Klauk and Prawl, 1984

Pera, 1978b
Duschene

Crowley, 1978

Pera, 1978b

Emery

Brown, 1975

Brown and Cook, 1982

\section{Garfield}

Hahl and Mundorff, 1968

Lowder, 1973

Rowley, Steven, and Mehnert, 1979

Sargent and Hansen, 1976

Smedley and others, 1976

Whelan, 1976

\section{Grand}

Baer and Rigby, 1978

Crowley, 1978

De Cicco and others, 1977

Rush and others, 1980

Sass and others, 1983a

Spicer, 1965

Iron

Adhidjaja, 1981

Best and Brimhall, 1974

Best and Keith, 1983

Chapman and others, 1981

Clement, 1981

Clement and Chapman, 1981

Cook, 1957

Cook and others, 1981

Crowley, 1977

Edmiston and Benoit, 1985

Erickson and Dasch, 1963

Gabbert, 1980

Gardner, Williams, and Hoover, 1976

Gardner, Williams, and Long, 1976

Geothermal Resources Council Bulletin, 1980c, 1982g, 1982j

Grant and Best, 1979

Hahl and Mundorff, 1968

Klauk and Gourley, 1983a, 1983b

Klauk and others, 1982

Kunze and Gould, 1981

Lowder, 1973

Mabey and Virgin, 1980

Mariner, Presser, and Evans, 1983

Mariner and others, 1977

Mariner and others, 1978

McHugh, Ficklin, Miller, and

Preston, 1981

McHugh and others, 1984

Nelson and Bromfield, 1979

$\mathrm{Pe}, 1980$

Pe and Cook, 1980a, 1980b 
Pera, 1978a

Pera and others, 1976

Peterson, 1972, 1974

Reimer, 1979

Rowley, 1978

Sargent and Hansen, 1976

Steven and Morris, 1984

U.S. Geological Survey, 1972b, 1979a

Whelan, 1976

White and others, 1978

\section{Juab}

Brown, 1975

Brown and Cook, 1982

Calkins, 1969

Callaghan and Thomas, 1939

Combs and others, 1983

Crosson, 1964

Galyardt and Rush, 1981

Geothermal Resources Council

Bulletin, 1981j, 1982g, 1982h

Gilbert, 1890

Hahl and Mundorff, 1968

Hewitt and others, 1972

Hogg, 1972b

Isherwood, 1967

Ives, 1946, 1947

Johnson, 1975

Lovering, 1965

Lovering and Goode, 1963

Lovering and Morris, 1965

Mariner, Presser, and Evans, 1983

Mariner and others, 1977

Mariner and others, 1978

Morris, 1978

Pampayan, 1984

Parry and others, 1976

Peterson, 1979

Peterson and Nash, 1980

Peterson and others, 1978

Reimer and others, 1976

Senterfit and Bedinger, 1976

Shawe, 1972

Smith, T. B., 1974

Smith, T. B., and others, 1978

Turley and Nash, 1980

\section{Kane}

Lowder, 1973

Sargent and Hansen, 1976

Smedley and others, 1976

Whelan, 1976

\section{Millard}

Adhidjaja, 1981

Aerial Surveys, 1978a, 1978b

Ash and others, 1979
Bamford and Christensen, 1979

Bowman and Rohrs, 1981

Brown, 1975

Brown and Cook, 1982

Brumbaugh, 1978

Brumbaugh and Cook, 1977

Callaghan and Thomas, 1939

Campbell and others, 1984

Carrier, 1979

Carrier and Chapman, 1979, 1980

Carter, 1978

Carter and Cook, 1978

Carter and others, 1977

Case, 1977

Caskey and Shuey, 1975

Cassel and others, 1978

Christensen, 1982

Clark, 1977

Combs and others, 1983

Condie and Barsky, 1972

Conrad, 1969

Cook, Serpa, and Pe, 1980

Cook, Serpa, Pe, and Brumbaugh, 1980

Cook and others, 1981

Cook and others, 1984

Crecraft, 1984

Crecraft and others, 1980a, 1980b, 1981

Crosson, 1964

Crowley, 1977

Cunningham and Steven, 1979b

Cunningham and others, 1983

DiPippo, 1985

Earth Science Laboratory/University of Utah Research Institute, 1979

Emiston and Benoit, 1985

Evans and others, 1980

Foley, 1982

Gabbert, 1980

Galyardt and Rush, 1981

Geothermal Resources Council Bulletin, 1981j, 1982c, 1982d, $1982 \mathrm{~g}, 1982 \mathrm{~h}, 1984 \mathrm{~b}, 1984 \mathrm{c}$, 1984d, 1984g, 1985c

GeothermEx, Incorporated, 1977

Gilbert, 1890

Glenn and Ross, 1982

Glenn and others, 1982

Hahl and Mundorff, 1968

Haugh, 1978b

Hewitt and others, 1972

Hoover, 1974

Hulen, 1978

Isherwood, 1967

Ives, 1947

Johnson, 1975

Laster and Douze, 1978
Lee, 1907

Liese, 1957

Lipman and others, 1975

Lipman and others, 1978

Lynch and Nash, 1980

Mabey and Virgin, 1980

Mariner, Presser, and Evans, 1983

Mariner and others, 1977

Mariner and others, 1978

McHugh, Ficklin, Miller, and Preston, 1981

McHugh and others, 1984

Moore, 1980b

Moore and others, 1979

Morris, 1978

Mudgett, 1964

Nash, 1981

Nash and Crecraft, 1982

Nash and Evans, 1978

Nash and others, 1978

Nathenson and Muffler, 1975

Nelson and Bromfield, 1979

Nielson and Moore, 1979

Nielson and others, 1980

Nielson and others, in press

Olson and Smith, 1976

Pampayan, 1984

Parry and others, 1976

Pera, 1978a

Peterson, 1972, 1974

Peterson, 1979

Peterson and Nash, 1980

Peterson and others, 1978

Phillips Petroleum Company, 1979

Phoenix Geophysics, Incorporated, 1976

Price, 1980, 1981

Pushkar and Condie, 1973

Reimer, 1979

Rodriguez, 1960

Ross, 1979

Ross and Moore, 1985

Ross, Moore, and Christensen, 1982

Senterfit and Bedinger, 1976

Serpa, 1980

Serpa and Cook, 1979

Sidle, 1984

Smith, T. B., 1974

Smith, R. B., 1977a

Smith, T. B., and others, 1978

Steven and Morris, 1983a, 1983b, 1984

Steven, Rowley, and Cunningham, 1978,1984

Steven and others, 1979

Stringfellow, 1982

Turley and Nash, 1980 
U.S. Geological Survey, 1972a, 1977, 1979b

Union Oil Company, 1973, 1974, 1976a, 1976b, 1978a, 1978b, 1978c, 1978d, 1978e, 1978f, $1978 \mathrm{~g}, 1979 \mathrm{a}, 1979 \mathrm{~b}$

White and others, 1978

Woodward, 1970

Yusas, 1979a

Zimmerman, 1961

\section{Morgan}

Pera, 1978b

Piute

Adhidjaja, 1981

Campbell and others, 1984

Carpenter and Young, 1962, 1963

Cook and others, 1981

Cook and others, 1984

Cunningham and Steven, 1979b

Cunningham and others, 1983

Cunningham and others, 1984

Hahl and Mundorff, 1968

Halliday and others, 1978

Mabey and Virgin, 1980

Machette and others, 1984

McHugh, Ficklin, Miller, and

Preston, 1981

McHugh and others, 1984

Nelson and Bromfield, 1979

Pera, 1978a

Reimer, 1979

Richardson, 1907

Rowley and others, 1980

Rowley, Cunningham, and Kaplan, 1981

Rowley, Steven, and Mehnert, 1981

Steven, Cunningham, and Anderson, 1984

Steven and Morris, 1984

Steven, Rowley, and Cunningham, 1978,1984

Tucker and others, 1980

Wender, 1976

Wender and Nash, 1976, 1979

Rich

Crowley, 1977, 1978

\section{Salt Lake}

Adhidjaja and others, 1981

Berge and others, 1981

Blair and Owen, 1981

Childs and others, 1980

Cole, 1982

Energy Services, Incorporated (Idaho Falls), 1982
Felmlee and Cadigan, 1978

Geothermal Resources Council Bulletin, 1980d, 1981d, 1981f, 1982e, 1982i, 1983c

Jensen and Qidwai, 1980?

Karlsson, 1984

Klauk and Darling, 1984

Klauk and others, 1981

Kunze and Gould, 1981

Kunze and Stoker, 1979

Kunze and others, 1980

Marsell, 1951

Meiiji Resource Consultants, 1983

Miller Floral Company, 1977

Morrison-Knudson, 1982

Murphy, 1978, 1981

Murphy and Gwynn, 1979a, 1979c

Pera, 1978b

Richardson, 1906

Shirley, 1984

Skalka, 1979

Smith, Christian, 1980

Terra Tek, 1980a

Utah Energy Office, 1981

Utah Geological and Mineral Survey, 1978,1981

Utah Roses, Incorporated, 1978

Wagstaff, 1982

Willis, 1980

\section{San Juan}

Crowley, 1978

Sass and others, 1983b

Smedley and others, 1976

\section{Sanpete}

Brown, 1975

Brown and Cook, 1982

Hahl and Mundorff, 1968

Richardson, 1907

Sevier

Adhidjaja, 1981

Aerial Surveys, 1978a, 1978b

Blair, 1980

Blair and Owen, 1982

Blair and others, 1980

Brown, 1975

Brown and Cook, 1982

Campbell and others, 1984

Carpenter and Young, 1962, 1963

Caskey and Shuey, 1975

Chapman and Harrison, 1978

Chapman and others, 1978a, 1978b

Childs and others, 1980

Cole, 1983

Cook and others, 1981
Cook and others, 1984

Cunningham and Steven, 1979a, 1979b

Cunningham and others, 1983

EG\&G, Incorporated, 1979

Earth Science Laboratory/University of Utah Research Institute, 1980

Foley, 1982

Gardner, Williams, and Brougham, 1976

Geothermal Resources Council Bulletin, 1982h

Gornitz, 1979

Hahl and Mundorff, 1968

Halliday, 1978

Halliday and Cook, 1978

Halliday and others, 1978

Harrison, 1980

Harrison and others, 1979

Harrison and others, 1980

Heyl, 1978

Hulen and Sandberg, 1981

Isherwood, 1967

Kilty, 1978

Kilty and others, 1978, 1979

Mabey and Virgin, 1980

Mariner and others, 1977

Mariner and others, 1978

Mase, 1979

Mase and Chapman, 1978

Mase and others, 1978

McHugh, Ficklin, Miller, and

Preston, 1981

McHugh and others, 1984

Miller, 1976

Monroe City, Utah - Municipality, 1977

Nash, 1981

Nathenson and Muffler, 1975

Nelson and Bromfield, 1979

Nielson and others, 1980

Parry and others, 1976

Pera, 1978a

Price, 1980, 1981

Reimer, 1979

Richardson, 1907

Rowley, Cunningham, and Kaplan, 1981

Rowley and others, 1980

Sandberg, 1980

Skalka, 1979

Smedley and others, 1977

Snow and Madsen, 1978

Steven, 1979

Steven and Morris, 1983b, 1984

Steven, Rowley, and Cunningham, 1978, 1984

Steven and others, 1979 


\author{
Stringfellow, 1982 \\ Terra Tek, 1980b \\ Tucker and others, 1980 \\ U.S. Geological Survey, 1979b \\ Ward and Sill, 1984 \\ Whelan, 1977 \\ Wilson, 1980 \\ Young and Carpenter, 1965 \\ Summit \\ Crowley, 1977, 1978 \\ Pera, 1978b \\ Utah Geological and Mineral Survey, \\ 1981
}

Tooele

Carpenter, 1913

Hogg, 1972b

Ives, 1946

Morris, 1978

Pampayan, 1984

Pera and others, 1977

Whelan and Petersen, 1974

Uintah

Crowley, 1978

Feltis and Goode, 1961

Goode, 1985

\section{Utah}

Davis and Cook, 1983

Klauk and Davis, 1984

Lovering, 1965

Lovering and Goode, 1963

Lovering and Morris, 1965

Pera, 1978b

Reimer and others, 1976

Richardson, 1906

Utah Geological and Mineral Survey, 1981

\section{Wasatch}

Baker, 1968, 1969

Jensen and Qidwai, 1980?

Kohler, 1979

Kohler and Kolesar, 1979

Utah Geological and Mineral Survey, 1981

\section{Washington}

Cook, 1957

Embree, 1970

Green, 1981

Green and Cook, 1980a, 1980b

Hamblin, 1963

Hausel and Nash, 1977

Lowder, 1973
Nash and Hausel, 1975

Noble and McKee, 1972

$\mathrm{Pe}, 1980$

Pe and Cook, 1980a, 1980b

U.S. Geological Survey, 1972b

Whelan, 1976

Weber

Allen and others, 1977

Cole, 1981

Glenn, Chapman, and others, 1980

Klauk and Prawl, 1984

Murphy, 1978

Murphy and Gwynn, 1979b

Pack and Carrington, 1921

\section{THERMAL AREAS}

Abraham Hot Springs

Callaghan and Thomas, 1939

Galyardt and Rush, 1981

Geothermal Resources Council Bulletin, 1982h

Gilbert, 1890

Hewitt and others, 1972

Ives, 1947

Johnson, 1975

Mariner, Presser, and Evans, 1983

Mariner and others, 1977

Mariner and others, 1978

Parry and others, 1976

Peterson, 1979

Senterfit and Bedinger, 1976

Smith, T. B., 1974

Smith, T. B., and others, 1978

\section{Becks Hot Springs}

Cole, 1982

Murphy, 1981

Murphy and Gwynn, 1979c

Belmont (Udy) Hot Springs

Murphy, 1978

Murphy and Gwynn, 1979b

\section{Cove Fort}

Aerial Surveys, 1978a, 1978b

Ash and others, 1979

Bamford and Christensen, 1979

Bowman and Rohrs, 1981

Brumbaugh, 1978

Brumbaugh and Cook, 1977

Carter and others, 1977

Cassel and others, 1978

Christensen, 1982

Cook, Serpa, and Pe, 1980
Cook, Serpa, Pe, and Brumbaugh, 1980

Crowley, 1978

DiPippo, 1984, 1985

Earth Science Laboratory/University of Utah Research Institute, 1979

Edmiston and Benoit, 1985

Geothermal Resources Council Bulletin, 1982h, 1984b, 1984c, $1984 \mathrm{~d}, 1984 \mathrm{~g}, 1985 \mathrm{c}$

Glenn and Ross, 1982

Glenn and others, 1982

Laster and Douze, 1978

Mariner and others, 1978

Moore, 1980b

Moore and others, 1979

Nathenson and Muffler, 1975

Nielson and Moore, 1979

Nielson and others, 1980

Olson, 1976

Olson and Smith, 1976

Rodriguez, 1960

Ross, 1979

Ross and Moore, 1985

Ross, Moore, and Christensen, 1982

Smith, R. B., 1977a

Stringfellow, 1982

Union Oil Company, 1973, 1974, 1976a, 1976b, 1978a, 1978b, $1978 \mathrm{c}, 1978 \mathrm{~d}$,

1978e, 1978f, 1978g, 1979a, 1979b

U.S. Geological Survey, 1977

Ward and others, 1981

Whelan, 1977

White and others, 1978

\section{Crystal Hot Springs}

Berge and others, 1981

Blair and Owen, 1981

Energy Services, Incorporated (Idaho Falls), 1982

Felmlee and Cadigan, 1978

Geothermal Resources Council Bulletin, 1980d, 1981f, 1982e, 1982i, 1983c

Jensen and Qidwai, 1980?

Klauk and Darling, 1984

Klauk and others, 1981

Kunze and Gould, 1981

Kunze and Stoker, 1979

Kunze and others, 1980

Miller Floral Company, 1977

Morrison-Knudson, 1982

Murphy, 1978, 1981

Murphy and Gwynn, 1979a

Shirley, 1984

Skalka, 1979 
Smith, Christian, 1980

Terra Tek, 1980a

Utah Energy Office, 1981

Utah Geological and Mineral Survey, 1978

Utah Roses, Incorporated, 1978

Willis, 1980

\section{Joseph Hot Springs}

Gardner, Williams, and Brougham, 1976

Geothermal Resources Council Bulletin, 1982h

Halliday, 1978

Halliday and Cook, 1978

Mariner and others, 1977

Mariner and others, 1978

Nielson and others, 1980

Terra Tek, 1980b

Lund

Gardner, Williams, and Hoover, 1976

White and others, 1978

Meadow-Hatton

Sidle, 1984

Midway Hot Springs

Baker, 1968, 1969

Jensen and Qidwai, 1980?

Kohler, 1979

Kohler and Kolesar, 1979

\section{Monroe-Red Hill Hot Springs}

Blair, 1980

Blair and Owen, 1982

Blair and others, 1980

Chapman and Harrison, 1978

Chapman and others, 1978a, 1978b

Childs and others, 1980

Cole, 1983

Earth Science Laboratory/University of Utah Research Institute, 1980

EG\&G; Incorporated, 1979

Gardner, Williams, and Brougham, 1976

Geothermal Resources Council Bulletin, 1982h

Gornitz, 1979

Halliday, 1978

Halliday and Cook, 1978

Halliday and others, 1978

Harrison, 1980

Harrison and others, 1979

Harrison and others, 1980

Heyl, 1978

Hulen and Sandberg, 1981
Kilty, 1978

Kilty and others, 1978, 1979

Mariner and others, 1977

Mariner and others, 1978

Mase, 1979

Mase and Chapman, 1978

Mase and others, 1978

Miller, 1976

Monroe City, Utah - Municipality, 1977

Nathenson and Muffler, 1975

Nielson and others, 1980

Parry and others, 1976

Samberg, 1980

Skalka, 1979

Snow and Madsen, 1978

Stringfellow, 1982

Terra Tek, 1980b

Ward and Sill, 1984

Whelan, 1977

Wilson, 1980

\section{Newcastle}

Chapman and others, 1981

Clement, 1981

Clement and Chapman, 1981

Denton, 1976

Geothermal Resources Council Bulletin, 1980c

Kunze and Gould, 1981

Mariner and others, 1978

\section{Roosevelt Hot Springs}

Abou-Sayed and others, 1977

Allen, 1983

Asten, 1983

Atkinson, 1981

Atkinson and Meyer, 1980

Ballantyne, G. H., 1978

Ballantyne, J. M., 1978, 1980

Ballantyne and Parry, 1978, 1979

Bamford, 1978

Bamford and others, 1980

Batzle and Simmons, 1976

Berge and others, 1976, 1977

Berge and others, 1981

Bowman, 1979

Bowman and Rohrs, 1981

Brown, 1982b, 1983

Brown, 1977

Brown and Mansure, 1981

Brumbaugh and Cook, 1977

Bryant, 1977

Bryant and Parry, 1977

Burbank City Public Service Department, 1977

Butz, 1980
Butz and Plooster, 1979

Capuano and Bamford, 1978

Capuano and Cole, 1982

Carlston, 1982

Carson and Livesay, 1981

Carter and others, 1977

Cassel and others, 1978

Christensen and others, 1980

Christensen and others, 1983

Chu, 1980

Chu and others, 1979

Ciancanelli, 1977

Ciancanelli and Corman, 1978

Combs and others, 1982

Combs and others, 1983

Cook and Carter, 1978

Crebs, 1975

Crebs and Cook, 1976

Crebs and others, 1977

Cremer, 1980

Crowley, 1978

Denton, 1977

DiPippo, 1984, 1985

Douze and Laster, 1979

Durham, 1977

Earth Science Laboratory/University of Utah Research Institute, 1979

East, 1981

Edmiston and Benoit, 1985

Evans and Nash, 1975

Forrest, 1980

Frangos and Ward, 1980

Geonomics, Incorporated, 1976b

Geothermal Power Corporation, $1978 \mathrm{a}, 1978 \mathrm{~b}, 1982$

Geothermal Resources Council Bulletin, 1981b, 1981h, 1981i, $1981 \mathrm{k}, 1982 \mathrm{a}, 1982 \mathrm{~b}, 1982 \mathrm{f}$, 1982h, 1982k, 1983a, 1983b, $1984 \mathrm{a}, 1984 \mathrm{e}, 1984 \mathrm{f}, 1985 \mathrm{a}$

GeothermEx, Incorporated, 1977

Geotronics Incorporated, 1976

Gertson and Smith, 1979

Getty Oil Company, 1978a, 1978b

Glenn and Hulen, 1979a, 1979b

Glenn, Hulen, and Nielson, 1980

Glenn and others, 1982

Helton Engineering and Geological Services, Incorporated, 1978

Hewitt and others, 1972

Hinkle, 1980, 1981

Hinkle and Harms, 1978

Hinkle and others, 1978

Hulen, 1978

Iyer, 1980

Iyer and others, 1980

Jamin, 1982

Jensen and Qidwai, 1980? 
Katz, 1977

Katzenstein and Jacobson, 1976

Kellog and Cook, 1979

Keys, 1979

Koenig and others, 1976

Koenig and Peterson, 1977

Kruger and Semprini, 1983

Laster and Douze, 1978

Leitner, 1978

Lenzer and others, 1976

Liaw and Suyenaga, 1982, 1983

Lin, 1981

Lovell and others, no date

Luth and Hardee, 1980

Mariner and others, 1978

Mathews, 1979

Mathews and LaDelfe, 1981

Matlick and Shiraki, 1981

McKinney, 1978

Micro Geophysics, 1977

Moore, 1980a

Moore and others, 1983

Murphy and Entingh, 1981

Nash, 1976

Nash and others, 1978

Nathenson and Muffler, 1975

Nielson, 1978, 1980

Nielson and Moore, 1979

Nielson and others, 1978

Nielson and others, 1979

Nielson and others, 1980

Olson, 1976

Olson and Smith, 1976

Olson and others, 1976

Parry, 1978

Parry, Ballantyne, and Bryant, 1980

Parry, Ballantyne, Bryant, and Dedolph, 1980

Parry, Nash, Bowman, and others, 1977

Parry, Nash, and Ward, 1977

Parry and others, 1976

Parry and others, 1978
Petersen, 1973, 1975a, 1975b

Petrick, 1976

Phillips Petroleum Company, 1980

Rasband, 1981, 1982, 1983

Robinson and Iyer, 1979, 1981

Rohrs, 1980

Rohrs and Bowman, 1980

Rohrs and Parry, 1978

Ross, Nielson, and Moore, 1982

Ross and others, 1981

Roxlo, 1980

Rudisill, 1978

Sandberg, 1980

Savino and others, 1982

Schaff, 1981

Seismic Exploration Incorporated, 1977

Shannon, Goff, and others, 1983

Shannon, Pettitt, and others, 1983

Sill, 1981, 1982

Sill and Bodell, 1977

Sill, Chapman, and others, 1977

Sill and Johng, 1979

Sill and Ward, 1978

Sill, Ward, and others, 1977

Smith, G. E., 1977

Smith, R. B., 1977a

Smith, J. L., 1980

Stringfellow, 1982

Thermal Power Company, 1976, 1977a, 1977b

Tripp, 1978

Tripp and others, 1976

U.S. Geological Survey, 1976

University of Denver, Denver

Research Institute, 1978

Wannamaker, 1978

Wannamaker and Hohmann, 1980

Wannamaker and others, 1978

Wannamaker and others, 1979

Wannamaker and others, 1980, 1983

Ward, 1983a, 1983b

Ward, Bowman, and others, 1978
Ward, Cook, and others, 1974

Ward, Glen, and others, 1975

Ward, Parry, and others, 1978

Ward, Rijo, and Petrick, 1975

Ward and Sill, 1976a, 1976b, 1984

Ward and others, 1977

Ward and others, 1981

White and others, 1978

Wilson, 1980

Wilson and Chapman, 1978, 1979, 1980

Young and others, 1979

Yusas, 1979b

Yusas and Bruhn, 1979

Zandt and others, 1982

Thermo Hot Springs

Cole, 1983

Crowley, 1978

Durham and Hoops, 1977

Edmiston and Benoit, 1985

Gardner, Williams, and Long, 1976

Klauk and Gourley, 1983

Mariner and others, 1977

Mariner and others, 1978

Mariner, Presser, and Evans, 1983

Petersen, 1973

Rowley and Lipman, 1975

Sawyer, 1977

Sawyer and Cook, 1977

White and others, 1978

Utah Hot Springs

Murphy, 1978

Murphy and Gwynn, 1979b

Wasatch Hot Springs

Cole, 1982

Karlsson, 1984

Murphy, 1981

Murphy and Gwynn, 1979c 


\title{
UTAH GEOLOGICAL AND MINERAL SURVEY
}

\author{
606 Black Hawk Way \\ Salt Lake City, Utah 84108-1280
}

THE UTAH GEOLOGICAL AND MINERAL SURVEY is one of eight divisions in the Utah Department of Natural Resources. The UGMS inventories the geologic resources of Utah (including metallic, nonmetallic, energy, and groundwater sources); identifies the state's geologic and topographic hazards (including seismic, landslide, mudflow, lake level fluctuations, rockfalls, adverse soil conditions, high groundwater); maps geology and studies the rock formations and their structural habitat; provides and disseminates educational materials concerning the geology of Utah; and provides information to decisionmakers at local, state, and federal levels.

THE UGMS is organized into five programs. Administration provides support to the programs. The Economic Geology Program undertakes studies to map mining districts, to monitor the brines of the Great Salt Lake, to identify coal, geothermal, uranium, petroleum and industrial minerals resources, and to develop computerized resource data bases. The Applied Geology Program responds to requests from local and state governmental entities for site investigations of critical facilities, documents, responds to and seeks to understand geologic hazards, and compiles geologic hazards information. The Geologic Mapping Program maps the bedrock and surficial geology of the state at a regional scale by county and at a more detailed scale by quadrangle.

THE INFORMATION PROGRAM distributes publications, and answers inquiries from the public and manages the UGMS library. The UGMS Library is open to the public and contains many reference works on Utah geology and many unpublished documents about Utah geology by UGMS staff and others. The UGMS has begun several computer data bases with information on mineral and energy resources, geologic hazards, and bibliographic references. Most files are not available by di-ect access but can be obtained through the library.

THE UGMS PUBLISHES the results of its investigations in the form of maps, reports, and compilations of data that are accessible to the public. For future information on UGMS publications, contact the UGMS Sales Ofrice, 606 Black Hawk Way, Salt Lake City, Utah 84108-1280. 